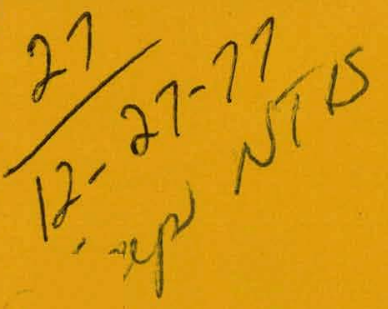

$$
\begin{array}{r}
\text { BNWL-RAP }=19 \\
\text { UC }=11
\end{array}
$$

Pacific Northwest Energy Related

Regional Assessment Program

\title{
Energy and Water Consumption of Pacific Northwest Irrigation Systems
}

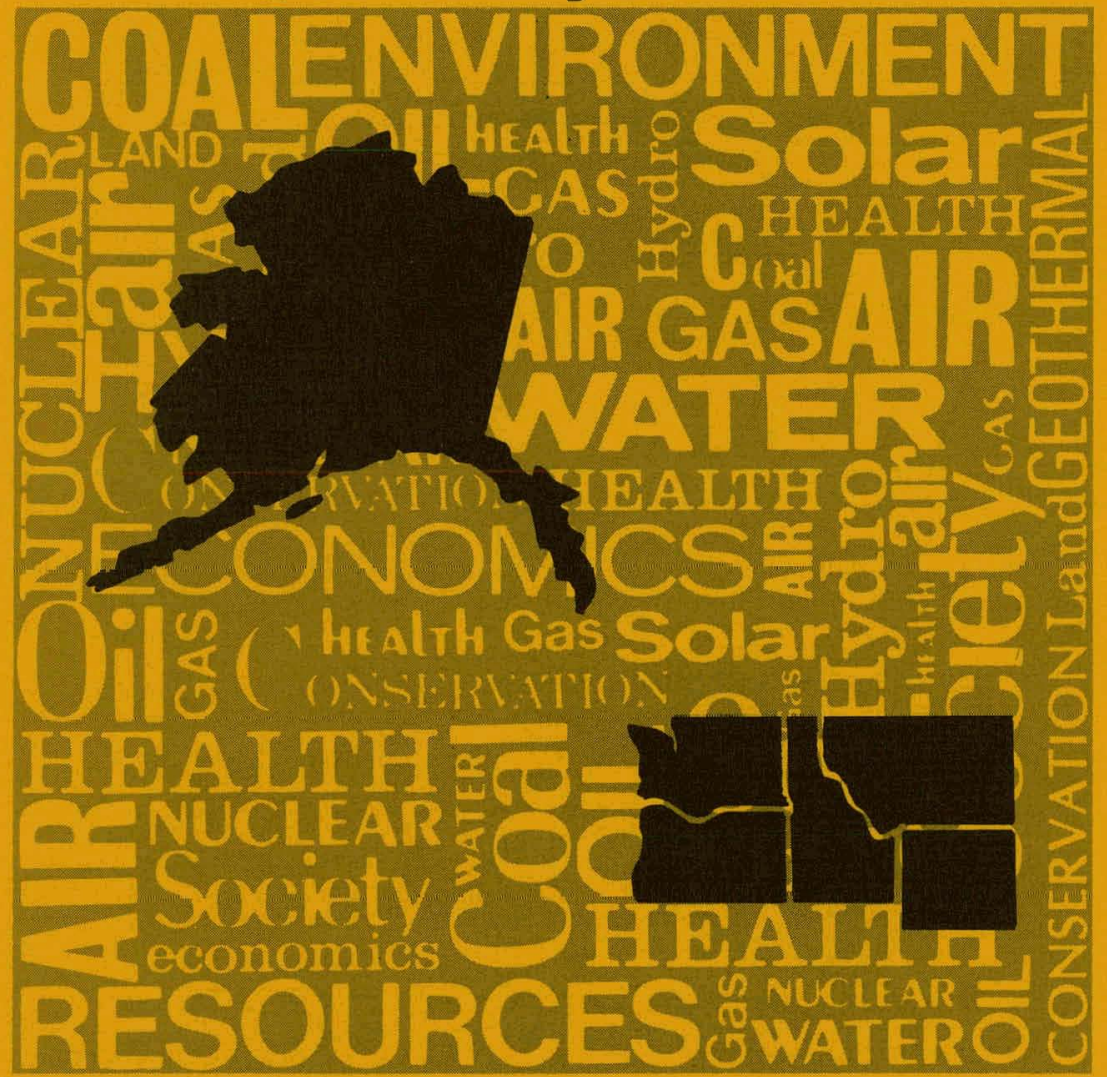

\section{September 1977}

Prepared for the U.S. Energy

Research and Development Administration under contract AT(45-1):1830

\section{Battelle}

Pacific Northwest Laboratories

Oregon

University 


\section{DISCLAIMER}

This report was prepared as an account of work sponsored by an agency of the United States Government. Neither the United States Government nor any agency Thereof, nor any of their employees, makes any warranty, express or implied, or assumes any legal liability or responsibility for the accuracy, completeness, or usefulness of any information, apparatus, product, or process disclosed, or represents that its use would not infringe privately owned rights. Reference herein to any specific commercial product, process, or service by trade name, trademark, manufacturer, or otherwise does not necessarily constitute or imply its endorsement, recommendation, or favoring by the United States Government or any agency thereof. The views and opinions of authors expressed herein do not necessarily state or reflect those of the United States Government or any agency thereof. 


\section{DISCLAIMER}

Portions of this document may be illegible in electronic image products. Images are produced from the best available original document. 


\section{NOTICE}

This report was prepared as an account of work sponsored by the United States Government. Neither the United States nor the Energy Research and Development Administration, nor any of their employees, nor any of their contractors, subcontractors, or their employees, makes any warranty, express or implied, or assumes any legal liability or responsibility for the accuracy, completeness or usefulness of any information, apparatus, product or process disclosed, or represents that its use would not infringe privately owned rights.

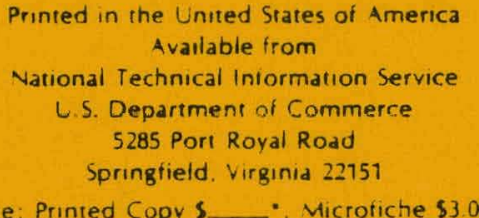

Price: Printed Copy s__. Microfiche $\$ 3.00$

$\begin{array}{lc}\text {-Pages } & \text { NTIS } \\ \text { Selling Price } \\ 001-025 & \$ 4.50 \\ 026-050 & \$ 5.00 \\ 051-075 & \$ 5.50 \\ 076-100 & \$ 6.00 \\ 101-125 & \$ 6.50 \\ 126-150 & \$ 7.00 \\ 151-175 & \$ 7.75 \\ 176-200 & \$ 8.50 \\ 201-225 & \$ 8.75 \\ 226-250 & \$ 9.00 \\ 251-275 & \$ 10.00 \\ 276-300 & \$ 10.25\end{array}$


ENERGY AND WATER CONSUMPTION

$\mathrm{OF}$

PACIFIC NORTHWEST IRRIGATION SYSTEMS

by

\author{
Larry D. King \\ Robert B. Wensink \\ John $W$. Wolfe \\ Marvin N. Shearer
}

September 1977

Project Report

This reporn was prepared as an account of work
sponsored by the United States Govemment. Neither the
United States not the United States Department of
Energ, nor any of their employees, nor any of their
contractors, subcontractors, or their employees, makes
any warranty, express or implised, or assumes any legal
liability or responsibility for the accurney, completeness
or usefulness of any information, apparatus, product or
process disclosed, or represents that its use would not
infringe privately owned rights.

for

Impact of Technology, Cropping Patterns and

Capital Investment on Irrigation Energy

Requirements in the Pacific Northwest

Performed by: Oregon State University

Corvallis, oregon 97331

Under contract to: Battelle

Pacific Northwest Laboratories

Richland, washington 99352 
TABLE OF CONTENTS

Page

List of Tables ii

List of Figures vii

Acknowledgment. ix

Glossary of Terms xi

Introduction 1

Objectives 3

Data Collection Procedure 3

Field Data 8

Computer Model Data 9

Model Inputs 13

Subregional Results 15

Subregion 1 -- Northern Idaho 16

Subregion 2 -- Upper Columbia 24

Subregion 3 -- Yakima 34

Subregion 4 -- Upper Snake 38

Subregion 5 -- Central Snake 53

Subregion 6 -- Lower Snake 69

Subregion 7 -- Mid-Columbia 81

Subregion 8 -- Lower Columbia . 96

Subregion 9 -- Willamette 99

Subregion 10 -- Coastal . 102

Subregion 11 -- Puget Sound 113

Subregion 12 -- Oregon Closed Basin 117

Subregion 13 -- Klamath, . 126

Subregion 1.4 -- Bear River 130

Regional and State Summary 133

References 136 
List of Tables

Table

$\underline{\text { Page }}$

1975 water requirements and energy

consumption for irrigation in the Pend Oreille Subarea.

21975 water requirements and energy

consumption for irrigation in the Spokane subarea.

31975 water requirements and energy

consumption of irrigation in the Kootenai Subarea.

41975 water requirements and energy consumption for irrigation in the Ferry stevens subarea.

51975 water requirements and energy consumption of irrigation in the Big Bend Subarea.

61975 water requirements and energy consumption for irrigation in the Methow Okanogan Subarea.

$7 \quad 1975$ water requirenulis and energy consumption for irrigation in the Wenatchee Entiat Chelan Subarea.

81975 water requirements and energy consumption for irrigation in

Yakima Subregion.

91975 water requirements and eneryy consumption for irrigation in the West side Subarea.

101975 water requirements and energy

consumption for irrigation in Neely Milner Subarea. 
111975 water requirements and energy

consumption for irrigation in the

Northern Streams Subarea.

121975 water requirements and energy

consumption for irrigation in

Heise Neely Subarea.

131975 water requirements and energy

consumption for irrigation in

Henrys Fork Subarea.

141975 water requirements and energy

consumption for irrigation in

South Fork subarea.

151975 water requirements and energy

consumption for irrigation in

Boise Subarea.

161975 water requirements and energy

consumption for irrigation in

Bruneau Subarea.

$17 \quad 1975$ water requirements and energy consumption for irrigation in the Owyhee subarea.

181975 water requirements and energy

consumption for irrigation in

Payette Subarea.

191975 water requirements and energy consumption for irrigation in the Weiser Subarea.

201975 watcr requirements and energy

consumption for irrigation in the Burnt Powder Subarea.

211975 water requirements and energy

consumption for irrigation in

Malheur Subarea. 
221975 water requirements and energy -

consumption for irrigation in the Clearwater subarea.

231975 water requirements and energy consumption for irrigation in the Palouse Lower Snake Subarea.

241975 water requirements and energy consumption for irrigation in the Grande Ronde Subarea.

251975 water requirements and energy consumption for irrigation in

Salmon subarea.

261975 water requirements and energy consumption for irrigation in the Upper Salmon subarea.

271975 water requirements and energy consumption for irrigation in Walla Walla Subarea.

1975 water requirements and energy

consumption for irrigation in Northside Columbia subarea.

1975 water requirements and energy consumption of irrigation in the Umatilla subarea.

1975 water requirements and energy consumption for irrigation in the John Day Subarea.

311975 water requirements and enexgy consumption of irrigation in the Deschutes subarea.

321975 water requirements and energy consumption for irrigation in the Hood Subarea. 
331975 water requirements and energy consumption for irrigation in the Lower Columbia Subregion.

341975 water requirements and energy consumption for irrigation in the Willamette subregion.

$35 \quad 1975$ water requirements and energy consumption for irrigation in the Washington Coastal Subarea.

361975 water requirements and energy consumption for irrigation in the oregon Coastal subarea.

371975 water requirements and energy consumption for irrigation in the Umpqua Subarea.

381975 water requirements and energy consumption for irrigation in the Rogue subarea.

$39 \quad 1975$ water requirements and energy consumption for irrigation in the Puget sound subarea.

$40 \quad 1975$ water requirements and energy consumption for irriqation in the Fort Rock, Christmas Lake, and Chewaucan Subarea. ,

411975 water requirements and energy consumption for irrigation in the Silvies, Silver, and Donner und Blitzen subarea.

42. 1975 water requirements and energy consumption for irrigation in the Alvord, Catlow, and Warner subarea. 
$43 \quad 1975$ water requirements and energy consumption for irrigation in the Klamath subregion.

441975 water requirements and energy consumption for irrigation in the Bear River Subregion. .

451975 water requirements and energy. consumption tor irrigation in each oubrcgion and etate in the reginn. 


\section{List of Figures}

Figure

Page

1 Map of Washington, Oregon, and Idaho, partitioned into 45 drainage basins.

2 Map of Subregion 1 containing Pend Oreille, Kootenai, Spokane and Lower Clark Fork Subareas.

3 Map of Subregion 2 containing Methow

Okanogan, Ferry Stevens, Big Bend, and Wenatchee Entiat Chelan Subareas. Map of Subregion 3 containing Yakima River Basin.

5. Map of Subregion 4 containing West Side, Neely Milner, Northern Streams, Heise Neely, Henrys Fork and South Fork Subareas.

6 Map of Subregion 5 containing Burnt Powder, Malheur, Weiser, Payette, Boise, Bruneau, and Owyhee Subareas.

7 Map of Subregion 6 containing Palouse Lower Snake, Grande Ronde, Clearwater, Salmon, and Upper Salmon Subareas.

8 Map of Subregion 7 containing Northside Columbia, Walla Walla, Umatilla, Hood, John Day and Deschutes Subareas.

9 Map of Subregion 8 containing the Lower Columbia River Basin.

10 Map of Subregion 9 containing the willamette River Basin.

11 Partial map of Subregion 10 containing the Washington Coastal subarea. 
$\underline{\text { Page }}$

12 Partial map of Subregion 10 containing the 103 Oregon Coastal, Umpqua and Rogue subareas.

13 Map of Subregion 11 containing puget sound area.

14 Map of Subregion 12 containing Fort Rock Christmas Lake - Chewaucan, Silvies Silver - Donner und Blitzen, and Alvord Catlow - Warner Subareas.

15. Map of Subregion 13 containing the Klamath Nrainage Basin.

16 Map of Subregion 14 containing Bear River 130 Basin. 


\section{ACKNOWLEDGMENT}

The preparation of this report was supported in part by Grant No. EY-76-S-06-2227, Task Agreement No. 25, U. S. Energy Research and Development Administration via contract to Battelle Northwest Laboratories. The cooperation of John B. Burnham, Program Manager and J. W. Currie, Senior Research Economist, Battelle Northwest, Richland, Washington, is gratefully acknowledged.

In addition, the authors sincerely appreciate the technical assistance of the following individuals and organizations:

Mel A. Hagood, Washington Extension Irrigation and water Specialist

Dorrell C. Larsen, Idaho Extension Irrigationist Numerous utility company personnel throughout the region, especially:

Bill Berry, Idaho Power Company -.

Keith Hartner, Central Electric Cooperative

Lavell J. Jensen, Utah Power and Light Company

Andrew H. Schmidt, Pacific Power and Light Company

Dick Murphy, Portland General Electric

Ted Trahan, California-Pacific Utilities Company

James R. Thompson, for Harney Electric Cooperative

Chester M. Moore, Jerry Lenzen, and Cam Downing, Bonneville Power Administration

Abner Bardal, Bureau of Reclamation, Klamath Falls

Jack Rowell and Lester Persson, Bureau of Reclamation, Northwest Regional Office, Boise

The managers of numerous irrigation districts and county extension agents in Oregon, Washington, and Idaho: 
The editorial assistance of Carol I. Small was instrumental to the completion of this report. Thanks is also extended to Suse S. Kelley and pete Lyngstrand for technical assistance with respect to map production, and to Harash $V$. Saluja for data analysis. Finally, typing by Barbara A. McVicar, Cindy M. Pratt, Marilyn R. Moore, and Carol $I$. Small made possible the professional and timely presentation of this publication. 


\section{GLOSSARY OF TERMS}

Below is a list of technical expressions, in alphabetical order, frequently used throughout this report. Definition of these expressions should clarify the intentions of the authors, and aid the reader in his understanding of the material.

Consumptive use= The amount of water used by the vegetative growth of a given area in transpiration and building of plant tissue and that evaporated from adjacent soil or intercepted precipitation on the plant foliage in any specified time.

Effective rainfall = Precipitation falling during the growth period of the crop that is available to meet the consumptive use of the crop. It does not include such precipitation as is lost to deep percolation below the root zone or to surface runoff.

Gravity diversion = Diversion of irrigation water without the aid of pumps.

Groundwater sources = Irrigation water obtained from underground aquifers.

Irrigation

application

efficiency
= The ratio of the quantity of water effectively put into the crop root zone and utilized by growing crops to the quantity applied. Usually expressed as a percentage. 
MWH

Net irrigation requirements

Net water

requirements

Pumping diversion

Pumping plant efficiency

Surface water sources
= Megawatt hours $(1,000$ kilowatt hours $)$.

= The depth of irrigation water, exclusive of precipitation or stored soil moisture, required consumptively for crop production.

= Net irrigation requirement plus water required for other uses such as leaching, etc.

$=$ The pumping of irrigation water into community conveyance systems. In some cases, the quantity of water pumped in a subarea may exceed the water applied because some of the water may be re-lifted (pumped) more than once. At the point of delivery, the individual farmer may either re-pump the water intu his irrigation system or obtain the water by gravity diversion.

$=$ The efficiency of motor times the efficiency of the pump. Combined efriciency of pump and motor considered as a unit.

$=$ Surface sources = irrigation water obtained from lakes, springs, streams or community conveyance systems. 
Subregion 7: John Day Subarea

Changes in:

$$
\begin{array}{lll}
\text { Solid set }-80 \text { acres } & \text { p. } 91 \\
\text { Big gun } & -353 \text { acres } & \text { p. } 91 \\
\text { Gravity }-33,776 \text { acres } & \text { p. } 91
\end{array}
$$

Subregion 12: Fort Rock, Christmas Lake and Chewaucan Subarea Changes in:

$$
\begin{array}{ll}
\text { Hand move }-0 \text { acres } & \text { p. } 121 \\
\text { Side roll }-5,615 \text { acres } & \text { p. } 121
\end{array}
$$

Subregion 12: Silvies, Silver and Donner und Blitzen Subarea

Changes in:

$\begin{array}{lll}\text { Center pivot } & -4,096 \text { acres } & \text { p. } 123 \\ \text { Hand move } & -8,995 \text { acres } & \text { p. } 123 \\ \text { Side roll } & -10,205 \text { acres } & \text { p. } 123\end{array}$

Changes in:

Table 41

On-farm subtotal - 111,447 acres p. 122

Regional and State Summary, Oregon

Changes in text:

$\begin{array}{lll}\text { Center pivot } & -101,387 \text { acres } & \text { p. } 133 \\ \text { Hand move } & -405,579 \text { acres } & \text { p. } 133 \\ \text { Side roll } & -333,906 \text { acres } & \text { p. } 133 \\ \text { Solid set } & -26,762 \text { acres } & \text { p. } 133 \\ \text { Big gun } & -29,413 \text { acres } & \text { p. } 133 \\ \text { Gravity } & -953,340 \text { acres } & \text { p. } 133\end{array}$

Changes in:

Table 45 (Subregion 9)

Acres irrigated - 262,063 acres p. 134

NOTE: Although minor changes in the mix of irrigation systems resulted in a slight change in electrical energy consumption, we did not note those changes since they were less than $1.0 \%$. 


\section{INTRODUCTION}

Before 1900, United States agriculture relied primarily upon animal and human power for the energies to produce, process and distribute its food products. The inventions of electricity and the internal combustion engine coupled with the abundance of cheap energy supplies initiated a substitution of machine power for on-farm animal and human labor early in the twentieth century. The utilization of fertilizers, herbicides and pesticides, which require extensive energies to produce, have also increased the indirect energy consumption in agriculture. Increased farm specialization and consumer preferences for convenient foods (extended processing) have required more energies for transporting, hauling, storing and processing of our food stuffs. Thus, agriculture has contributed to the nation's growth and prosperity by substituting energy and machines for labor and resources which were then used in non-agricultural industries. However, this substitution has required agriculture to consume vast amounts of energy; agriculture presently consumes 13 percent of the total U.S. energy budget to produce, harvest, process and distribute the nation's food supply (Hirst, 1974).

In the western part of the United States, one of the largest single energy consuming agricultural operations is irrigation. Barnes et al. (1973) indicated that over 34 milition acres of land are irrigated in the 18 western "irrigation states." This acreage (within the states of Washington, Oregon, California, Idaho, Nevada, Utah, Arizona, Montana, Wyoming, Colorado, New Mexico, North Dakota, South Dakota, Nebraska, Kansas, Oklahoma, Texas, and Louisiana) comprises approximately ten percent of the cropland in the United States. On much of this acreage, 50 to 100 percent 
of the crop production is dependent upon proper application of irrigation water. A study in California (Williams, 1974) found that for nine crops grown extensively in that state, the application of irrigation water was by far the largest single factor affecting crop production. The study estimated that a 50 percent reduction in applied. irrigation water would result in an average yield reduction of 49 percent for the nine crops and a reduction. in crop value of over $\$ 1$ billion.

Irrigation in the Pacific Northwest is also an energyintensive process which represents a major part of the total energy used in farm level food production. Since 1950, several major developments have precipitated pronounced increases in irrigation energy requirements. For example, the invention of efficient high-lift pumps, labor saving equipment, new uses for irrigation sprinklers, and profitable cropping patterns have substantially escalated irrigation energy consumption in the Pacific Northwest in the past 25 years. Until recently, energy prices have remained relatively low and constant.

The next 25 . years will continue to experience advanced irrigation technologies. In addition to technological development, however, the cost of energy and water will certainly rise while their availabilities become increasingly constrained. The depletion of ground water in several parts of the United States could also potentially increase the irrigation burden of the Pacific Northwest. Tiastly, parts of the Pacific Northwestern water supply are directly convertible to energy via hydroelectric generation. This study proposes to make realistic projections relative to present and future interactions of the above components. 


\section{OBJECTIVES}

The objectives of this study are to:

1. Determine present (1975) energy, water and labor requirements of irrigated agriculture in the Pacific Northwestern states of Idaho, Oregon and Washington.

2. Project, using alternative scenarios, electrical energy, water and labor requirements associated with irrigated agricultural production in 1985 and 2000 in Idaho, Oregon and Washington.

3. Assess changes in the region's irrigated crop production demands and determine the relative trade-offs between energy consumption, water utilization and labor requirements.

The first objective is presented in this report. The remaining objectives will be addressed during the second phase of this study.

\section{DATA COLLECTION PROCEDURE}

To determine the amount of energy consumed by irrigation, one needs to know what types of irrigation systems exist and how irrigation water is obtained. Basically, water may be pruvided by the fullowing sources: wells. (groundwater); streams and gravity diversion canals (surface water); or canals and pipes fed by pumped diversions (either groundwater or surface water sources). In a pumped diversion, water is pumped from either groundwater or surface water before delivery for use. Pumping diversions may also occur where water in a gravity diversion must be re-lifted to higher elevations to increase utilization. 
In some cases, diversion pumping requires that irrigation water be pumped twice. To know where this occurs, one needs to understand the basic types of irrigation systems.

Irrigation methods can be partitioned into two broad categories: surface systems and sprinkler systems. Surface systems generally transport water from its source to the field in either an. open ditch, which may or may not be lined with an impermeable material, or through low pressure pipes. The water is then distributed by either flooding the complete field or by furrow irrigation, which necessitates the wetting of only part of the surface (from $1 / 2$ to $1 / 5$ ). There are approximately 43 million acres under surface irrigation in the United states.

Sprinkler irrigation systems differ from surface in that water is distributed over the field via pressurized irrigation sprinklers. There are seven basic types of pressurized systems which range in operating pressure from over $100 \mathrm{psi}$ for big guns and some center pivot systems to less than $10 \mathrm{psi}$ for drip systems. The six types of pressurized systems and their approximate U.S. acreages are: hana move (4.4 milliun dires), side roll ( 3.2 million acres), solid set and permanent (with a combined 1.1 million acres), big gun ( 0.6 million acres), center pivot ( 3.9 million acres), and drip (75,000 acres). These systems collectlvely ilfigale over 11 militun aurou.

The hand move system is typically hand assembled for a particular irrigation set, operated for approximately 10 hours, disassembled and transported by human labor approximately 50 feet across the field to be reassembled and operated for the next set. This method requires sprinkler operating pressures of approximately $50 \mathrm{psi}$ and a significant amount of human labor. 
One means of reducing the human labor requirement is to install wheels on the lateral so that the pipe can be rapidly moved from one irrigation set to the next. This system, called side roll, substantially reduces labor demands. Another means of reducing labor is to position laterals at 50 foot spacings across the complete field. This system, called solid set, instead requires a large number of pipes and sprinklers to cover the field. To facilitate harvesting, this set-up is usually disassembled after the last irrigation.

The permanent system is the ultimate in a labor saving scheme. The system's supply lines and laterals are usually buried and in many cases the complete system is controlled by electronic clocks; only a minimum of labor is necessary. for maintenance operations. The big gun system has attempted to reduce both labor and initial investment by requiring only one large nozzle to irrigate a circular area; however, this system can require operating pressures in excess of 100 psi.

Another technique, called the center pivot, was first introduced in the late 1950's. This method utilizes one lateral to irrigate a circular pattern which usually encompasses 126 acres, requiring a minimum amount of labor and using sprinkler operating pressures between 70 and 90 psi. There are approximately 120,000 acres of center pivot systems in oregon near the Columbia River; over 80,000 acres of these were installed between 1972 and 1974 .

The last type of pressurized method is called the drip or trickle system. This requires low pressures (approximately $10 \mathrm{psi}$ ) and reduced labor requirements, and maximizes water application efficiency by providing an individualized emitter to each plant. The drip technique requires a large 
amount of plastic, polyethylene or PVC tubing which is usually installed directly below the ground surface. In addition to providing high water application efficiencies, the system can be used to irrigate areas which would otherwise be totally impossible to irrigate. For example, avocado orchards in California are irrigated on rocky hillsides with slopes in excess of $55^{\circ}$. Drip systems have been experimentally tested on over 100 different crops with varying degrees of success. One major problem with this method is the plugging of individual drippers, holes or emitters. However, drip has only been under commercial production for a few years and research is continuing to alleviate many of the existing problems.

All the above irrigation systems are used throughout the region, which encompasses the three contiguous states of Washington, Oregon and Idaho. The region is partitioned into 45 drainage basins shown in Figure 1 . Thirty-six of the drainage basins are contained wholely within one of the states; washington, Oregon and Idaho have 8, 14 and 14 complete drainage basins within their state boundaries, respcctively. In addition, 9 drainage basins are shared between two states: three between washington and oregon, three between Oregon and Idaho, and three between washington and Idaho. All data have. been collected and partitioned into one of the above drainage basins.

The data collected in this study wrrr obtained by the following procedures: ' l) actual field data estimated, and. 2) data generated from computer models. The two procedures were designed as a check and balance data collection system. 


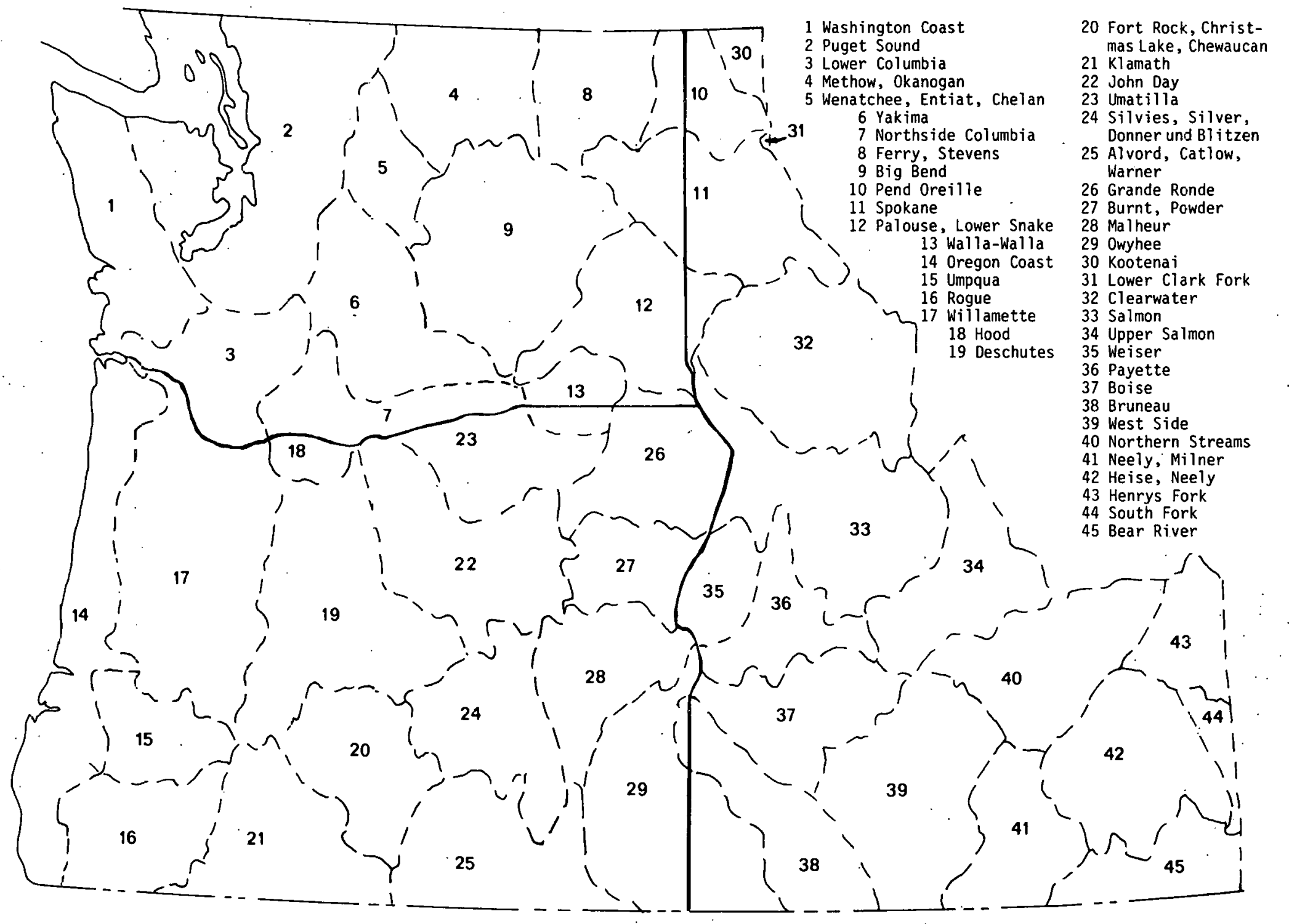

Figure 1. Map of Washington, oregon, and Idăho, partitioned into 45 drainage basins. 


\section{Field Data}

A variety of different crops is grown in the Pacific Northwest using all seven of the above irrigation systems. county agricultural extension agents and state irrigation engineering specialists completed a detailed questionnaire for each crop grown in each drainage basin. The crop questionnaire addressed amount of water applied by each type of irrigation system source of irrigation water (ground wateror surface), pumping lifts, and power sources. Most of the information was obtained on a county basis and then allocated to the appropriate drainage basin.

Pumping lifts were also obtained from Oregon Water Resources Department (McCall, 1975; Sceva, 1966; Leonard, 1970; Bartholemew and Debow, 1970; Ducret and Anderson, 1965; Helm, 1968; Price and Johnson, 1965; Frank and Johnson, 1970, 1975; Hampton, 1963; Price, 1961; Forworthy et al., 1964; Leonard. and Harris, 1974. Pumping plant efficiencies for on-farm pumps were calculated from Pacific Gas and Electric Company's irrigation pumping plant field data. The efficiencies of pumping plants operated by various irrigation districts or the Bureau of Reclamation were calculated whenever sufficient information was available. When sufficient information was not available, efficiencies were estimated according to the horsepower of the pumping plant.

Irrigation cnergy consumption הata were collected from ut1lity cullpanies, Lonnevillc Powcs Administration, Federn 1 Power Commission, and Bureau of Reclamation regional offices. Most of the energy data were supplied on a regional or macroscopic basis and had to he prorated to the crop-irriqation systems in the area represented by the corresponding energy data. The allocation of an area's recorded energies to specific 
crop-irrigation system utilized crop-climatic data and irrigation and pumping plant efficiencies. It was found that almost all the energy used for irrigation pumping in the region was electrical energy. Other energy sources were either not mentioned by those answering the questionnaire or stated as being insignificant. Due to conversion to electrical energy, the use of alternate energy sources for irrigation pumping is diminishing in the region.

\section{Computer Model Data}

The first computer program simulates the net seasonal water requirements of a crop in a specific climatological environment. The model determines, on a monthly basis, the crop's consumptive use and the effective rainfall. The net monthly irrigation requirement of the crop is obtained by subtracting monthly rainfall from monthly consumptive use. Net monthly irrigation requirements are then accumulated over the crop's growing period to produce a seasonal net irrigation requirement. Lastly, a salinity leaching requirement is determined. The total seasonal net water requirement is obtained.by summing leaching and net irrigation requirements.

The computer model calculate monthly consumptive use, $u$, by the following modified Blaney-Criddle method (U. S. Department of Agriculture, S.C.S., 1970):

$$
u=\left(k_{t}\right)\left(k_{c}\right)(f)
$$

where:

$$
\begin{aligned}
& \mathrm{k}_{t}=0.0173 t-0.314 \\
& t=\text { mean monthly temperature, } o_{F} \\
& k_{c}=\text { monthly crop growth stage coefficient }
\end{aligned}
$$




$$
\begin{aligned}
\mathrm{f}= & \frac{(p)(t)}{100} \\
\mathrm{p}= & \text { percentage of daylight as a function of area's } \\
& \text { latitude. }
\end{aligned}
$$

Average monthly effective rainfall, $r_{e}$, is calculated from

$$
r_{e}=\left[0.70917\left(r_{t}\right)^{0.82416}-0.11556\right](10.0 .0242 u)
$$

where:

$$
\begin{aligned}
F & =0.531747+0.295164(D)-0.057697\left(D^{2}\right)+0.003804\left(D^{3}\right) \\
D & =\text { depth of irrigation, inches } \\
r_{t} & =\text { mean monthly rainfall, inches }
\end{aligned}
$$

When the depth of irrigation equals 3 inches, $F=1.0$. The values of $r_{e}$ used are based on a 3-inch net irrigation application.

Leaching requirements are a function of average annual rainfall and assume 0.5 inches of runoff per year in semi-arid and arid climates. A leaching ratio, LR, is first calculated, assuming irrigation water is not applied for leaching (U. $S$. Department of Agriculture, S. C. S., 1970):

$$
L R=\frac{D_{i w}\left(E C_{i w}\right)}{\left(D_{r W}+D_{i w}\right) E C_{d W}}
$$

where:

$$
\begin{aligned}
\mathrm{D}_{\mathrm{iw}}= & \text { depth of irrigation water required to satisfy } \\
& \text { both consumption use conditions and leaching } \\
& \text { requirements } \\
\mathrm{EC}_{\mathrm{iw}}= & \text { electrical conductivity of the irrigation water } \\
& \text { in millimhos per centimeter }
\end{aligned}
$$




$$
\begin{aligned}
\mathrm{D}_{\mathrm{rw}}= & \text { depth of annual rainwater entering the soil } \\
& \text { profile in inches } \\
\dot{E C}_{\mathrm{dw}}= & \text { maximum permissible electrical conductivity of } \\
& \text { drainage effluent for the irrigated crop in millimhos } \\
& \text { per centimeter. }
\end{aligned}
$$

Electrical conductivity values, $E C_{i w^{\prime}}$ of total salt content for each drainage basin are reported in the Annual summary of Water Quality Data for selected sites in the Pacific Northwest (1972). Average annual net leaching requirement, $L_{n}$, is then calculated from

$$
L_{n}=\frac{U}{I-L R}-\left(D_{r W}+D_{C W}\right)
$$

where:

$$
\begin{aligned}
\mathrm{U} & =\text { seasonal consumptive use } \\
\mathrm{D}_{\mathrm{CW}} & =\text { seasonal net irrigation requirement } \\
\mathrm{LR} & =\text { leaching ratio } \\
\mathrm{D}_{\mathrm{rW}} & =\text { depth of annual rainwater entering the soil profile. }
\end{aligned}
$$

The program then increases the seasonal consumptive use, $U$, by 5 inches of watcr and repeats the above calculations. The simulated net leaching requirement is then determined by interpolating between the two calculated values of $I_{n}$. That is,

$$
\frac{L_{n}}{I_{n}-I_{n o}}=\frac{5}{L_{n 5}-I_{n o}}
$$


where:

$$
\begin{aligned}
L_{n}= & \text { net seasonal leaching requirement } \\
L_{n o}= & \text { net leaching requirement when no irrigation water } \\
& \text { is used for leaching } \\
L_{n 5}= & \text { net leaching requirement when } 5 \text { additional inches } \\
& \text { of irrigation water are used for leaching. }
\end{aligned}
$$

If the simulated net leaching requirement is less than zero or the vearly precipitation for the region exceeds 30 inches, the leaching requirement is set to zero.

The program then determines the planting date for annuals (or the first water use date of perennials) as a function of critical spring temperatures for each selected crop in the 1975 season. The model proceeds to determine the average end of growing season for the selected crop, based on critical fall temperatures of the crop and average daily temperatures. The potential growing season for the crop is the difference between planting date and end.of growing season date. From the potential growing season, the model subtracts the maximum growing season of the crop, divides the total by two and then adds this quotient to the earliest planting date. The final value is recorded as the average planting date and is used to determine annual water requirements. If the critical fall temperature in 1975 occurs earlier than the mean crltical temperature date, Lhe growing season is terminated. That is, if a killing frost occurs bcfore the crop is mature, the growing season is terminated on that day.

The second model calculates the energy consumed by a particular irrigation system for a specific crop-climatic condition. This model requires the following general inputs: net crop water requirements, type of irrigation system, 
irrigation application efficiency, pumping lifts from water source to field, and pumping plant efficiency. The first computer model determines total seasonal net water requirements, in acre-inches per season. Using these total seasonal net water requirements, the second model calculates the total required pumping energy by

$$
\mathrm{KWH}=\frac{(1.024)(\mathrm{AI})(\mathrm{L})}{(12)(\mathrm{EFF})(\mathrm{IAEF})}
$$

where:

$$
\begin{aligned}
\mathrm{AI}= & \text { seasonal net water requirement in acre-inches per } \\
& \text { season } \\
\mathrm{L}= & \text { pumping } 1 \text { ift required to transfer water from the } \\
& \text { source to the field level plus the operating head of } \\
& \text { the irrigation system, in feet } \\
\mathrm{EFF}= & \text { pumping plant efficiency, as a decimal } \\
\mathrm{IAEF}= & \text { irrigation application efficiency, as a decimal } \\
I .024= & \text { energy conversion factor. }
\end{aligned}
$$

Pumping plant efficiency and pumping lift data were obtained for each drainage basin within this study (see Field Data section).

After' the computer models predict water and energy requirements, the values are compared to the data reported in the field study. Where discrepancies exist, both data collection procedures are analyzed for possible input errors and then re-evaluated.

\section{Model Inputs}

To predict the water and energy requirements of a crop in a specific climatological region required data concerning a 
crop's growing attributes, its environmental characteristics, and the type of irrigation system distributing the water. Plant attributes included crop consumptive use and crop coefficient values. Crop coefficient values were obtained. from USDA-SCS (1970) and consumptive use values from net irrigation requirements of crops in each state (Watts et al., 1968; Sutter and Corey, 1970; and Jensen et al., 1969). Environmental characteristics included mean monthly temperatures, rainfalls and percent of daylight periods. These values were obtained from local climatic data.

Irrigation system parameters included pumping plant efficiencies, pumping lifts, irrigation application efficiencies, and operating pressures. Pumping plant efficiencies were a. function of individualized pumps. However, values in general were between the following ranges: 72-82 percent for large Bureau of Reclamation pumps; 65-75 percent for large private pumps; 54-65 percent for intermediate pumps; and 50-58 percent for small on-farm pumps. Typical irrigation application efficiencies and operating heads for each system were as follows:

\begin{tabular}{|c|c|c|c|}
\hline System & $\begin{array}{l}\text { Operating head } \\
\text { (ft) }\end{array}$ & $\frac{\text { Application }}{\text { Humid }}$ & $\frac{\text { efficiency }(\%)}{\text { Arid }}$ \\
\hline Center pivot & 200 & 87 & 82 \\
\hline Hand move & 155 & 75 & 65 \\
\hline side roll & 160 & 75 & 65 \\
\hline Solid set & 160 & 75 & 65 \\
\hline Permanent & 160 & 75 & 65 \\
\hline Big gun & 300 & 74 & 66.5 \\
\hline Drip & 50 & 90 & 85 \\
\hline Gravity $^{\star}$ & 0 & 45 & 45 \\
\hline Gravity (return) & 15 & 80 & 80 \\
\hline
\end{tabular}

* When pumping is required to deliver water for gravity systems, 5 feet of additional lift is used.

On-farm pumping lifts were obtained from each area in this study anc are reported in Tables $1-4.4$. 
The complete region encompasses the three contiguous states of Washington, Oregon and Idaho and has been partitioned into 45 drainage basins (subareas shown in Figure 1). All data have been collected and classified by drainage basin. The drainage basins have been organized into 14 subregions which are presented in the following sections. Tabular results for each subarea contain total irrigated acreage, irrigated crops, water applied and energy consumed in 1975.

Throughout most of the region, 1975 was climatically a wetter and cooler year than the "average irrigation season." Irrigation systems are typically designed to provide sufficient water during peak periods for eight out of every ten years. That is, from a statistical perspective eight out of ten systems should be able to satisfy peak irrigation demands during 80 percent of the irrigation seasons. This parameter is extremely important since a shortage of moisture during critical plant stages may result in catastrophic yield reductions. Since the 1975 irrigation climatic season was lower than "average," this study also included an engineering design requirement for each crop in the following tables. These engineering design values represent the water necessary to satisfy evapotranspiration demands and provide a sufficient crop eight out of every ten years. Therefore, the engineering design values are probably more meaningful than the 1975 values for predicting future irrigation water and energy requirements. The efficiencies used for the various systems in calculating the design water requirements are considered the same as 1975 systems. 


\section{SUBREGION . 1}

Northern Idaho

This subregion is located in the northeastern corner of the region (see Figure 2). Approximately 30 percent is in northeastern washington and the remaining 70 percent in northern Idaho.

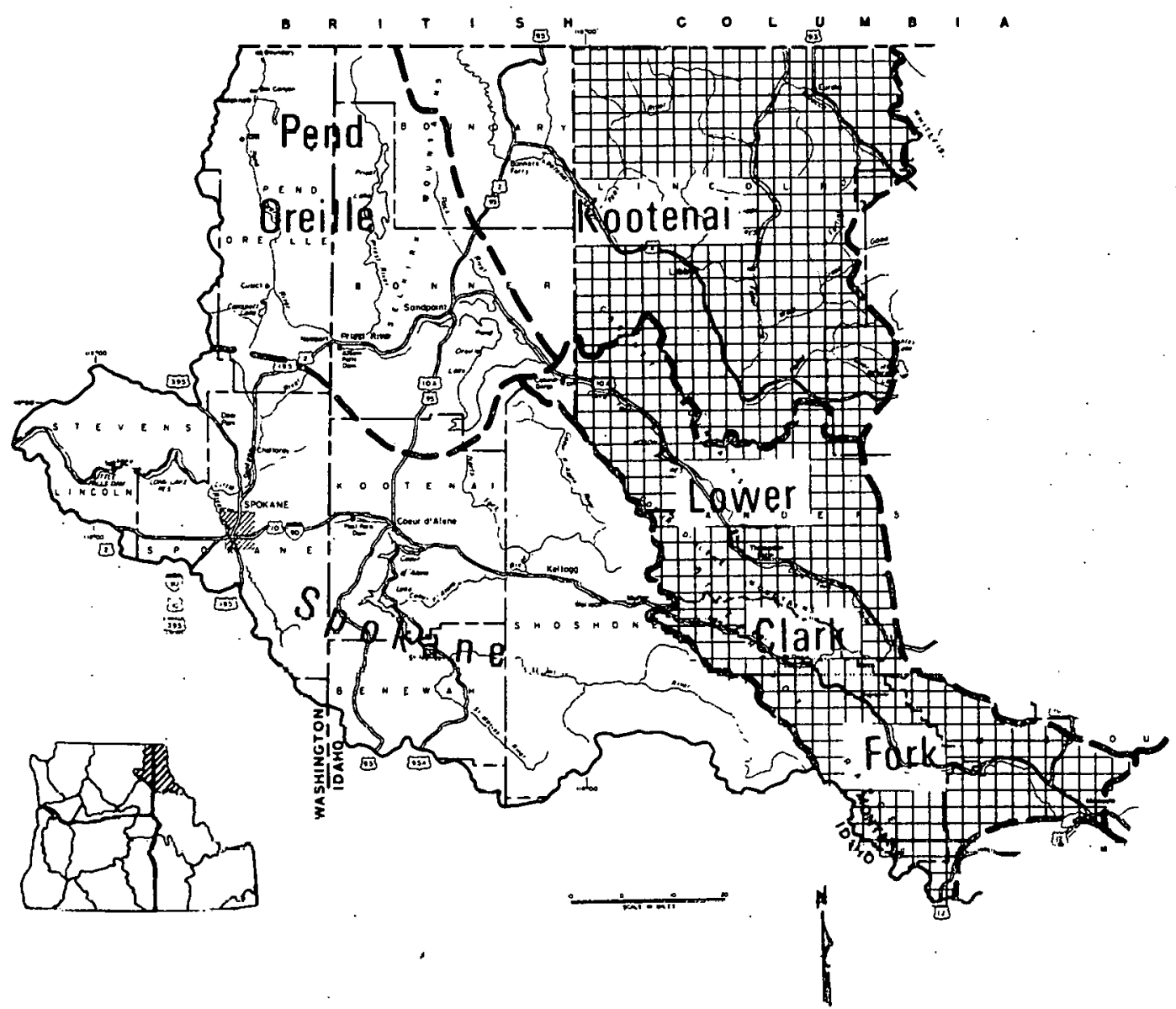

Figure 2. Map of Subregion 1 containing Pend Oreille, Kootenai, Spokane and Lower Clark Fork Subareas. 
To simplify the data, this subregion has been divided into four subareas. One subarea -- Spokane -- is an entire river drainage basin while the remaining three subareas -Kootenai, Lower Clark Fork and Pend Oreille -- contain only part of their complete river drainage basins.

This subregion contained 52,850 acres of irrigation in 1975. Of this total, Spokane irrigated 48,050 acres, Pend Oreille contained 3,800 acres, Kootenai irrigated 1,000 acres, and the Lower Clark Fork Subarea was void of irrigation. Hay and pasture were the primary (59 percent of total) crops in the subregion. Additional irrigated crops included: small grains, field corn, mint, hops, dill, vegetables, potatoes, grass seed, fruit, nuts and berries.

Approximately 111,876 acre-feet of water were applied and 58,140 MWH of electricity were consumed for irrigation in 1975 . Engineering design requirements for this corresponding period were 120,376 acre-feet of water and 63,009 $\mathrm{MWH}$ of electricity. Since 1975 was a wetter than average year, actual utilization was less than engineering design values. Irrigation systems and their corresponding acreages used within the subregion were as follows: hand move, 35,114 acres; side roll, 10,190 acres; gravity, 6,610 acres; big gun, 836 acres; and drip, 100 acres.

\section{Pend Oreille Subarea}

This subarea is located in the northeastern edge of Washington and northern portion of Idaho. The complete drainage basin is truncated by the U.S.-Canadian border. This subarea contains the Pend Oreille and Priest Lakes. Agriculture, mining, and recreation are the major economic components of the area. 
Irrigation energy and water data are shown in Table 1 for the Pend Oreille Subarea, which contained 3,800 acres of irrigation, with hay and pastures registering 3,047 acres ( 80 percent) of the total. Also, small acreages of grain, field corn, mint, hops, dill, vegetables and potatoes were irrigated in this subarea.

The 3,800 irrigated acres had 6,936 acre-feet of water applied and used 2,328.6 MWH of electricity in 1975. Engineering design requirements for the corresponding data were 7.093 acrefeet of water and 2,414.9 MWH of electricity. Surface sources. which supplied 92.1 percent of the irrigation water to this subarea, had average on-farm pumping lifts of 27 feet; the remaining water was obtained from groundwater with average lifts of 150 feet. Irrigation pumping was primarily an individualized farmer operation throughout the subarea. Lastly, irrigation systems, by major types, were as follows: hand move, 2,246 acres; gravity, 560 acres; side roll, 490 acres; and big gun, 324 acres.

\section{Spokane Subarea}

This drainage area is partitioned between washington and Idaho. The subarea contains the Spokane River drainage which originates in Coeur d'Alene Lake, the St. Joe River and the coeur a'Alene Rlver. The Bltterroot Range on the Idaho-Montana border forms the eastern boundary of this subarea. Major economic activities include irrigated agriculture, wood products, mining and recreation.

The energy consumption and water requirements for Spokane subarea are reported in Table 2; over 48,000 acres were irrigated in 1975. Hay and pasture accounted for 57 
Table 1. 1975 water requirements and energy consumption for irrigation in the Pend Oreille Subarea.

\begin{tabular}{|c|c|c|c|c|c|c|c|}
\hline \multirow[b]{3}{*}{ Crop } & \multirow[b]{3}{*}{$\begin{array}{c}\text { Acres } \\
\text { Irrigated }\end{array}$} & \multicolumn{3}{|c|}{1975 Requirements } & \multicolumn{3}{|c|}{ Design Requirements ${ }^{2}$} \\
\hline & & \multirow[b]{2}{*}{$\begin{array}{l}\text { Water } \\
\text { Applied } \\
(\mathrm{ac}-1 \mathrm{n} / \mathrm{ac})\end{array}$} & \multicolumn{2}{|c|}{ Energy Consumed ${ }^{1}$} & \multirow[b]{2}{*}{$\begin{array}{c}\text { Water } \\
\text { Applied } \\
(a c-i n / a c)\end{array}$} & \multicolumn{2}{|c|}{ Energy Consumed ${ }^{1}$} \\
\hline & & & $\begin{array}{l}\text { Ground- } \\
\text { water } \\
(\mathrm{KWH} / \mathrm{ac})\end{array}$ & $\begin{array}{l}\text { Surface } \\
\text { Water } \\
\text { (KWH/ac) }\end{array}$ & & $\begin{array}{l}\text { Ground- } \\
\text { water } \\
(\mathrm{KWH} / \mathrm{ac})\end{array}$ & $\begin{array}{l}\text { Surface } \\
\text { Water } \\
\text { (KWH/ac) }\end{array}$ \\
\hline $\begin{array}{l}\text { Hay and pasture } \\
\text { Grain } \\
\text { Field corn } \\
\text { Mint, hops, \& dill } \\
\text { Vegetables } \\
\text { Fruits, nuts \& berries } \\
\text { Potatoes }\end{array}$ & $\begin{array}{r}3, C 47 \\
100 \\
324 \\
60 \\
20 \\
5 \\
244\end{array}$ & $\begin{array}{l}22.5 \\
18.5 \\
15.9 \\
29.8 \\
10.8 \\
19.1 \\
22.2\end{array}$ & $\begin{array}{r}1,117.2 \\
859.8 \\
1,090.3 \\
-- \\
501.9 \\
887.7 \\
1,048.7\end{array}$ & $\begin{array}{r}557.9 \\
513.1 \\
792.8 \\
0.0 \\
299.5 \\
529.7 \\
632.6\end{array}$ & $\begin{array}{l}22.5 \\
21.5 \\
19.6 \\
34.2 \\
12.3 \\
20.8 \\
23.8\end{array}$ & $\begin{array}{r}1,117.2 \\
999.2 \\
1,344.0 \\
-- \\
571.7 \\
966.7 \\
1,124.3\end{array}$ & $\begin{array}{r}557.9 \\
596.3 \\
976.6 \\
0.0 \\
341.1 \\
576.9 \\
678.2\end{array}$ \\
\hline Subtotal & $3, \varepsilon 00$ & $21.9^{3}$ & 612.8 & $\mathrm{KWH} / \mathrm{ac}^{4}$ & $22.4^{3}$ & 635.5 & $\mathrm{KWH} / \mathrm{ac}^{4}$ \\
\hline Pumping diversion & -- & -- & - & & -- & - & \\
\hline Total & 3,800 & $21.9^{3}$ & $612: 8$ & $\mathrm{KWH} / \mathrm{ac}^{4}$ & $22.4^{3}$ & 635.5 & $\mathrm{KWH} / \mathrm{ac}^{4}$ \\
\hline
\end{tabular}

$192.1 \%$ of the water was supplied by surface sources with average on-farm pumping 1 ifts of 27 feet and the remaining $7.9 \%$ from groundwater with average lifts of 150 feet.

2 Values represent the engineering sizing of water and energy required to provide a crop 8 years out of 10 .

3 Average water consumed for all crops in subregion.

4 Average energy required for all crops and water sources in subarea. 
Table 2. 1975 wate requirements and energy consumption, for irrigation in tize Spokane Subarea.

\begin{tabular}{|c|c|c|c|c|c|c|c|}
\hline \multirow{3}{*}{ Srop } & \multirow[b]{3}{*}{$\begin{array}{c}\text { Acres } \\
\text { Irrigated }\end{array}$} & \multicolumn{3}{|c|}{1975 Requirements } & \multicolumn{3}{|c|}{ Des1gn Requirements ${ }^{2}$} \\
\hline & & \multirow[b]{2}{*}{$\begin{array}{c}\text { Water } \\
\text { Applied } \\
(a c-1 n / a c)\end{array}$} & \multicolumn{2}{|c|}{ Energy Consumed ${ }^{1}$} & \multirow[b]{2}{*}{$\begin{array}{c}\text { Water } \\
\text { Applied } \\
(\mathrm{ac}-\mathrm{in} / \mathrm{ac})\end{array}$} & \multicolumn{2}{|c|}{ Energy Consumed $^{1}$} \\
\hline & & & $\begin{array}{l}\text { Ground- } \\
\text { water } \\
\text { (KWH/ac) }\end{array}$ & $\begin{array}{l}\text { Surface } \\
\text { Water } \\
\text { (KWH/ac) }\end{array}$ & & $\begin{array}{l}\text { Ground- } \\
\text { water } \\
\text { (KWH/ac) }\end{array}$ & $\begin{array}{l}\text { Surface } \\
\text { Water } \\
\text { (KWH/ac) }\end{array}$ \\
\hline $\begin{array}{l}\text { Hay and pasture } \\
\text { Grain } \\
\text { Vegetables } \\
\text { Fruits, nuts and berries } \\
\text { Grass seed } \\
\text { Field corn } \\
\text { Potatoes }\end{array}$ & $\begin{array}{r}27,334 \\
7,614 \\
2,700 \\
526 \\
9,706 \\
120 \\
50\end{array}$ & $\begin{array}{l}32.8 \\
17.1 \\
14.2 \\
21.9 \\
16.6 \\
21.7 \\
24.8\end{array}$ & $\begin{array}{r}1,418.6 \\
816.4 \\
675.1 \\
1,000.0 \\
794.4 \\
1,511.1 \\
1,198.0\end{array}$ & $\begin{array}{r}853.0 \\
.542 .8 \\
447.9 \\
645.3 \\
528.8 \\
1,163.9 \\
801.2\end{array}$ & $\begin{array}{l}34.0 \\
21.7 \\
15.4 \\
24.7 \\
18.8 \\
23.3 \\
30.3\end{array}$ & $\begin{array}{r}1,470.4 \\
1,036.0 \\
732.3 \\
1,127.9 \\
899.7 \\
1,622.6 \\
1,463.6\end{array}$ & $\begin{array}{r}884.2 \\
688.8 \\
485.8 \\
727.8 \\
598.9 \\
1,249.8 \\
978.8\end{array}$ \\
\hline Subtotal & $48,05 n$ & $25.8^{3}$ & 970.8 & $\mathrm{KWH} / \mathrm{ac}{ }^{4}$ & $27.8^{3}$ & $1,053.8$ & ${ }^{4} \mathrm{KWH} / \mathrm{ac}$ \\
\hline Pumping diversion & -- & $18,650 \mathrm{dc}-\mathrm{ft}$ & 8,569 & MWH & $20, C 97 . \subsetneq 30$ & $9,234.2$ & \\
\hline Tota1 & $\leq 8,050$ & $25.8^{3}$ & 1,149 & $.14^{4} \mathrm{KWH} / \mathrm{ac}$ & $27.8 \equiv$ & $1,245.9$ & $8^{4} \mathrm{KWH} / \mathrm{ac}$ \\
\hline
\end{tabular}

$137.8 \%$ of the water was suppied by surface souzces with average on-farm pumping lifts of 52 feet and the remaining $62.2 \%$ from groundwater Nith $^{2}$ average lifts of 157 .

2 Values represent the engineering sizing of water and energy required to provide a crop 8 years out of 10 .

${ }^{3}$ Average water consumed $\mathrm{f} \supset \mathrm{r}$ all crops in subregion.

4 Average energy required for all crops and water sources in subarea. 
percent of the subarea's total irrigation. Other irrigated crops include small grains, vegetables, fruits, nuts, berries, grass seed, field corn and potatoes.

Approximately 103,308 acre-feet of water were applied and 55,215 MWH of electricity were consumed for irrigation in 1975 . Corresponding engineering design requirements for the same period were 111,316 acre-feet of water and $59,869 \mathrm{MWH}$ of electricity. of the total water appiied in $1975,37.8$ percent was supplied from surface sources with average on-farm lifts of 52 feet; the remaining 62.2 percent was obtained from groundwater sources with average lifts of 157 feet. The subarea contains a Bureau of Reclamation project which provided water for 1,800 acres. Hand move was the major irrigation system type, with 31,880 acres. Additional systems included side rol1, 9,700 acres; gravity, 6,050 acres; big gun, 320 acres; and drip, 100 acres.

\section{Lower Clark Fork Subarea}

This drainage subarea includes those lands drained by the Clark Fork River downstream from Missoula, Montana to Pend Oreille Lake.' Ninety-eight percent of the Lower Clark Fork Subarea is located in Montana; the remaining 2 percent is in Idaho. This study determined irrigation energy and water data for Washington, Oregon and Idaho. Therefore, only a fraction of the drainage basin is included. Within this study's region (Idaho portion) there is no existing irrigated acreage. 
Kootenai Subarea

The Kootenai Subarea encompasses the entire Kootenai River drainage area in Idaho and Montana. Seventy-seven percent of this subarea is located in Montana, 23 percent in Idaho. As indicated above, only the Idaho irrigated acreage is included in this study.

Table 3 lists irrigation energy and water requirements during the 1975 season. This subarea irrigated only 1,000 acres. Seventy-three percent of the subarea (727 acres) contained hay and pasture. In addition, limited acreages of corn, vegetables, fruits, nuts, berries and potatoes were irrigated in 1975.

The subarea had 1,633 acre-feet of water applied and consumed 595.6 MWH of electricity for irrigation in 1975. Corresponding engineering design requirements were 1,966 acre-feet of water and 724.8 MWH of electricity. Since all water was obtained from surface sources with average on-farm pumping lifts of 25 feet, the per acre energy requirements were quite low relative to other subareas in this study. Irrigation systems were limited to hand move, 808 acres, and big gun, 192 acres. 
Table 3. 1975 water requirements and energy consumption of Irrigation in the Kootenai Subarea.

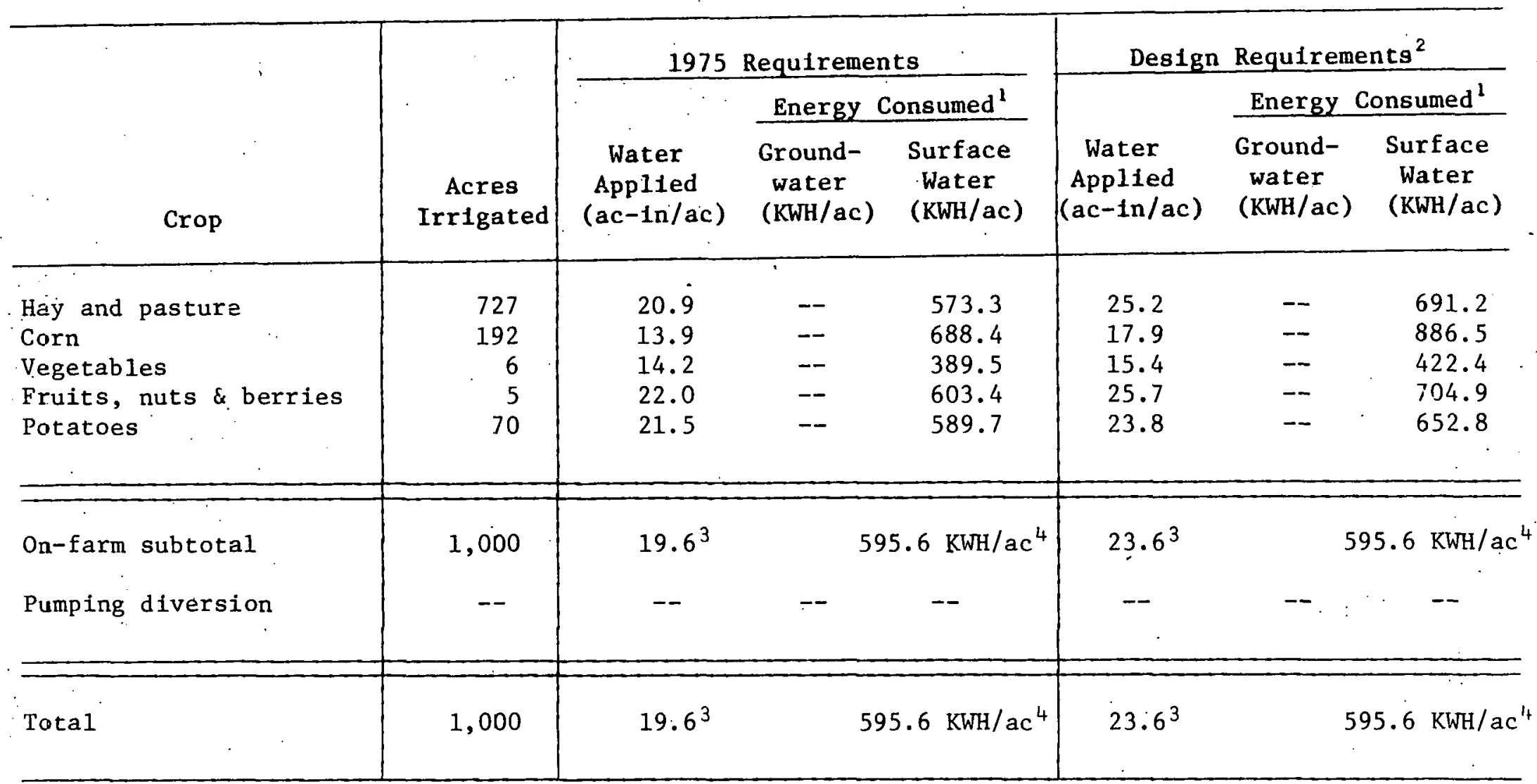

$1100 \%$ of the water was supplied by surface sources with average on-farm pumping 1 ifts of 25 feet.

${ }^{2}$ Values represent the engineering sizing of water and energy required to provide a crop 8 years out of 10 .

${ }^{3}$ Average water consumed for all zrops in subregion.

${ }^{4}$ Average energy: required for all crops and water sources in subarea. 


\section{SUBREGION 2}

Upper Columbia

This subregion lies completely within the north-central region of the state of Washington. The region's boundaries include the U.S.-Canadian border on the north; remaining boundaries form a line connecting the tributary drainage of the Columbia River upstream from the Snake River excluding the Yakima and Spokane Rivers.

This subregion is partitioned into the following four subareas: Methow Okanogan, Ferry Stevens, Big Bend, and Wenatchee Entiat Chelan, as shown in Figure 3. The subregion contained 767,400 acres of irrigation in 1975 on which $3,143,717$ acre-feet of water were applied and 2,075,173 MWH of electricity consumed. Engineering design requirements for 1975 were 3,082,944 acre-feet of water and 1,987,488 MWH of electricity. Though 1975 was a wetter than average climatic year, actual water and energy utilization were 1.03 percent of the engineering design requirements. This condition primarily resulted from over-irrigation of some crops in the Big Bend and Ferry Stevens Subareas.

Of the total irrigated acreage in the subregion, 90 percent was contained in Big Bend Subarea. In addition, hay and pasture were the predominant irrigated crop with 224,396 acres (30 percent of total). Uther irrigated crops included small grains, potatoes, sugar beets, field corn, vegetables, dry beand and peas, grass geeds and orchards. The region's. irrigation system types and their corresponding acreages were: side roll, 275,693 acres; gravity, 244,667 acres; center pivot, 132,200 acres; hand move, 72,240 acres; solid set and permanent, 40,000 acres; big gun, 1,700 acres; and drip, 900 acres. 


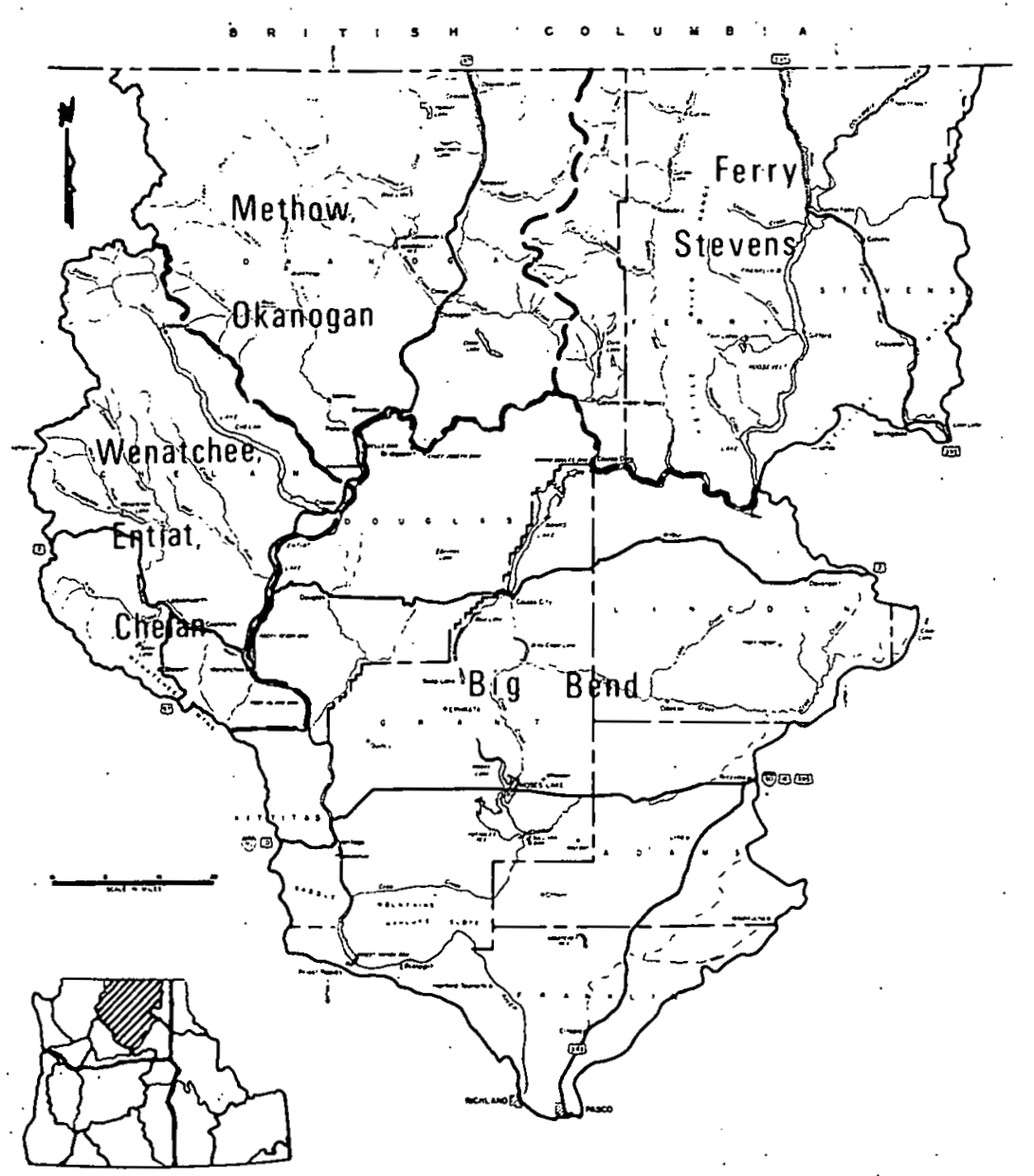

Figure 3. Map of Subregion 2 containing Methow Okanogan, Ferry Stevens, Big Bend, and Wenatchee Entiat Chelan Subareas.

\section{Ferry Stevens subarea}

Ferry Stevens subarea is located within the northeastern. section of this subregion. The area contains all of Ferry County and portions of Stevens and Pend Oreille Counties. Several rivers, including Kettle, Sanpoil, colville and the Columbia, are located within the subregion. 
Irrigation water and energy requirements are listed in Table 4. The subarea contained only 19,000 irrigated acres. Of this total, 16,992 acres ( 89 percent) contained hay and pasture. In addition, 1,985 acres of grain and 23 acres of fruit, nuts and berries were irrigated.

Approximately 68,400 acre-feet of water were applied and 36,478.1 MWH of electricity were consumed in 1975. corresponding engineering design requirements were 63,017 acre-feet of water and $33,468 \mathrm{MWH}$ of electricity. All crops in this subarea were over-irrigated relative to engineering design requirements. That is, optimum production could probably be achieved with less water utilization since 1975 was a wetter than average year. About 94.7 percent of the irrigation water was supplied by surface sources with on-farm average pumping lifts of 50 feet and the remaining 5.3 percent from groundwater with average lifts of 300 feet. In addition, pump diversions lifted 46,818 acre-feet of water 75 feet to surface sources by small irrigation projects. Hand move and side roll were the only two system types used in the subarea; their corresponding acreages were 12,500 and 6,500 acres, respectively.

\section{Big Bend Subarea}

This subarea derives its name from the big bend in the Columbia River which forms the area's northern and western boundaries in central Washington. The Big Bend subarea contains all of Grant and Douglas Counties, almost all of Franklin, Lincoln and Adams Counties and parts of Spokane and Kittitas counties. This region is relatively high and flat. 
Table 4. 1975 water requirements and energy consumption for irrigation in the Ferry Stevens Subarea.

\begin{tabular}{|c|c|c|c|c|c|c|c|}
\hline & \multirow[b]{3}{*}{$\begin{array}{c}\text { Acres } \\
\text { Irrigated }\end{array}$} & \multicolumn{3}{|c|}{1975 Requirements } & \multicolumn{3}{|c|}{ Design Requirements ${ }^{2}$} \\
\hline & & \multirow[b]{2}{*}{$\begin{array}{l}\text { Water } \\
\text { Applied } \\
(a c-1 n / a c)\end{array}$} & \multicolumn{2}{|c|}{ Energy Consumed ${ }^{1}$} & \multirow[b]{2}{*}{$\begin{array}{c}\text { Water } \\
\text { Applied } \\
(\mathrm{ac}-1 \mathrm{n} / \mathrm{ac})\end{array}$} & \multicolumn{2}{|c|}{ Energy Consumed } \\
\hline Crop. & & & $\begin{array}{l}\text { Ground- } \\
\text { water } \\
(\mathrm{KWH} / \mathrm{ac})\end{array}$ & $\begin{array}{l}\text { Surface } \\
\text { Water } \\
(\mathrm{KWH} / \mathrm{ac})\end{array}$ & & $\begin{array}{l}\text { Ground- } \\
\text { water } \\
(\mathrm{KWH} / \mathrm{ac})\end{array}$ & $\begin{array}{l}\text { Surface } \\
\text { Water } \\
\text { (KWH/ac) }\end{array}$ \\
\hline $\begin{array}{l}\text { Hay and pasture } \\
\text { Grain } \\
\text { Fruits, nuts } \& \text { berries }\end{array}$ & $\begin{array}{r}16,992 \\
1,985 \\
23\end{array}$ & $\begin{array}{l}45.2 \\
26.5 \\
43.0\end{array}$ & $\begin{array}{l}3,475.0 \\
2,039.1 \\
3,279.4\end{array}$ & $\begin{array}{r}1,571.0 \\
928.1 \\
1,477.5\end{array}$ & $\begin{array}{l}42.3 \\
18.5 \\
44.5\end{array}$ & $\begin{array}{l}3,236.5 \\
1,422.7 \\
3,165.0\end{array}$ & $\begin{array}{r}1,464.0 \\
647.5 \\
1,426.0\end{array}$ \\
\hline $\begin{array}{l}\text { On-farm subtotal } \\
\text { Pumping diversion }\end{array}$ & 19,000 & $\begin{array}{c}43.2^{3} \\
46,818 a c-f t\end{array}$ & $\begin{array}{r}1,599.6 \\
6,084:\end{array}$ & $\begin{array}{l}\mathrm{KWH} / \mathrm{ac}^{4} \\
\text { 9. } \mathrm{MWH}\end{array}$ & $\begin{array}{c}39.8^{3} \\
43,133 \mathrm{ac}-\mathrm{ft}\end{array}$ & $\begin{array}{r}1,466.4 \\
5,606 .\end{array}$ & $\begin{array}{l}4 \mathrm{KWH} / \mathrm{ac}^{4} \\
.0 \mathrm{MWH}\end{array}$ \\
\hline Tota1 & $19, \mathrm{COO}$ & $43.2^{3}$ & $1,919.9$ & $\mathrm{KWH} / \mathrm{ac}^{4}$ & $39.8^{3}$ & $1,761.5$ & $5 \mathrm{KWH} / \mathrm{ac}^{4}$ \\
\hline
\end{tabular}

$194.7 \%$ of the water was supplied by surface sources with average on-farm pumping 1ifts of 50 feet and the remaining $5.3 \%$ from groundwater with average lifts of 300 feet.

${ }^{2} \nabla a l u e s$ represent the engineering sizing of water and energy required to provide a crop 8 years out of 10 .

${ }^{3}$ tiverage water consumed for all crops in subregion.

${ }^{4}$ hverage energy required for all crops and water sources in subarea. 
Irrigation water applications and energy requirements are shown in Table 5 for the Big Bend Subarea. A total of 692,400 acres were irrigated in 1975. Small grains had 200,185 acres under irrigation; hay and pasture, 196,518 acres; sugar beets, 59,890 acres; dry beans and peas, 58,705 acres; and potatoes, 40,915 acres. In addition, acreages of field corn, vegetables, legume seed, fruits, nuts and berries were also irrigated.

The 692,400 irrigated acres had 2,798,450 acre-feet of water applied and $1,879, y 35$ MWH of electricity consumed in 197.5 . Corresponding engineering design requirements were $2,729,210$ acre-feet of water and $1,187,638 \mathrm{MWH}$ of electrieity. Several of the crops actually used more water, and subsequently energy, than that necessary for optimum production. These over-utilizations resulted in actual consumptions greater than engineering design requirements, though 1975 was a wetter than normal year.

In this subarea, 78.5 percent of the irrigation wates was supplied from surface sources with average on-farm pumping lifts of 5 feet and the romaining 21.5 percent from groundwater with average lifts of 340 feet. In addition, Grand Coulee Dam diverted 2,140,000 acre-feet of water with average lifts of 285 feet for use by surface sources; 818,919 acre-feet of water were reused by intercepting return flows and lifting the water 179 feet to field surfaces. Seven major irrigation system types were used in this subarea. Their types and acreages are as follows: 262,233 acres, side roll; 244,667 acres, gravity; 132,000 acres, center pivot; 40,000 acres, hand move; 10,000 acres, solid set; 2,000 acres; permanent; and 1,500 acres, big gun. 
Table 5. 1975 water requirements and energy consumption of irrigation in the Big Bend Subarea.

\begin{tabular}{|c|c|c|c|c|c|c|c|}
\hline \multirow[b]{3}{*}{ Crop } & \multirow[b]{3}{*}{$\begin{array}{c}\text { Acres } \\
\text { Irrigated }\end{array}$} & \multicolumn{3}{|c|}{1975 Requirements } & \multicolumn{3}{|c|}{ Design Requirements ${ }^{2}$} \\
\hline & & \multirow[b]{2}{*}{$\begin{array}{c}\text { Water } \\
\text { Applied } \\
(a c-1 n / a c)\end{array}$} & \multicolumn{2}{|c|}{ Energy Consumed ${ }^{1}$} & \multirow[b]{2}{*}{$\begin{array}{c}\text { Water } \\
\text { Applied } \\
(a c-1 n / a c)\end{array}$} & \multicolumn{2}{|c|}{ Energy Consumed ${ }^{1}$} \\
\hline & & & $\begin{array}{c}\text { Ground- } \\
\text { water } \\
\text { (KWH/ac) }\end{array}$ & $\begin{array}{l}\text { Surface } \\
\text { Water } \\
(\mathrm{KWH} / \mathrm{ac})\end{array}$ & & $\begin{array}{l}\text { Ground- } \\
\text { water } \\
(\mathrm{KWH} / \mathrm{ac})\end{array}$ & $\begin{array}{l}\text { Surface } \\
\text { Water. } \\
\text { (KWH/ac) }\end{array}$ \\
\hline $\begin{array}{l}\text { Hay and pasture } \\
\text { Grain } \\
\text { Potatoes } \\
\text { Sugar beets, sugar } \\
\text { Dry beans and peas } \\
\text { Field corn } \\
\text { Vegetables } \\
\text { Legume seed } \\
\text { Fruits, nuts \& berries } \\
\text { Unenumerated }\end{array}$ & $\begin{array}{r}196,518 \\
200,185 \\
40,915 \\
59,915 \\
58,705 \\
26.266 \\
32,021 \\
20,618 \\
21,880 \\
35,402\end{array}$ & $\begin{array}{l}62.6 \\
25.3 \\
40.9 \\
58.8 \\
50.1 \\
54.6 \\
49.9 \\
63.2 \\
81.7 \\
56.0\end{array}$ & $\begin{array}{l}4,655.3 \\
2,052.2 \\
3,488.4 \\
4,510.3 \\
3,862.9 \\
3,349.1 \\
3,436.2 \\
4,609.6 \\
5,672.6 \\
4,121.8\end{array}$ & $\begin{array}{r}893.5 \\
630.5 \\
1,155.6 \\
1,054.0 \\
757.5 \\
96.8 \\
354.1 \\
783.4 \\
590.2 \\
738.8\end{array}$ & $\begin{array}{l}65.9 \\
18.4 \\
38.9 \\
59.9 \\
40.1 \\
60.6 \\
54.6 \\
64.2 \\
89.5 \\
55.5\end{array}$ & $\begin{array}{l}4,802.8 \\
1,522,0 \\
3,352.4 \\
4,576.2 \\
2,938.4 \\
3,204.2 \\
3,612.2 \\
4,576.0 \\
6,214.1 \\
3,996.1\end{array}$ & $\begin{array}{r}920.3 \\
464.3 \\
1,107.2 \\
1,066.2 \\
576.2 \\
92.6 \\
372.2 \\
777.7 \\
646.5 \\
716.2\end{array}$ \\
\hline On-farm subtotal & 692,400 & $48.5^{3}$ & $1,331.7$ & $\mathrm{KWH} / \mathrm{ac}^{4}$ & $47.3^{3}$ & $1,232.7$ & $\mathrm{KWH} / \mathrm{ac}^{4}$ \\
\hline Pumping diversion & -- & $2,883,003$ & ft-ac 957 , & $848 \mathrm{MWH}$ & $2,811,671$ & $a c-f t$ & $148.67 \mathrm{MNH}$ \\
\hline Tota1 & 692,400 & $48.5^{3}$ & $2,715.1$ & $\mathrm{KWH} / \mathrm{ac}^{4}$ & $47.3^{3}$ & $2,581.8$ & $\mathrm{KWH} / \mathrm{ac}^{4}$ \\
\hline
\end{tabular}

$178.5 \%$ of the water was supplied by surface sources with average on-farm pumping lifts of 5 feet and the remaining $21.5 \%$ from groundwater with average lifts of 340 feet.

2 Values represent the engineering sizing of water and energy required to provide a crop 8 years out of 10 .

${ }^{3}$ Average water consumed for all crops in subregion.

4Average energy required for all crops and water sources in subarea. 


\section{Methow Okanogan Subarea}

This subarea lies within the northwestern portion of the subregion and contains the Methow and Okanogan River basins. The Methow River drains the eastern slopes of the Cascade Range with three major tributaries, Lost River, Chewack River and the Twisp River. The Okanogan River and its main tributary, the Similkameen River, obtain approximately 70 percent of their runoff from Canada.

Irrigation energy and water data for the Methow Okanogan Subarea are listed in Table 6. The subarea irrigated 26,000 acres containing 16,704 acres of orchards, 8,906 acres of hay and pasture, plus limited acreage in small grains and field crops. The 26,000 acres had 117,867 acre-feet of water applied and used 58,305 $\mathrm{MWH}$ of electricity in 1975. Corresponding èngineering design requirements were 126,967 acre-feet of water and 62,860 MWH of electricity. All of the water was obtained from surface sources with average on-farm pumping lifts of 75 feet. In addition, two Bureau of Reclamation projects delivered 19,908 acre-feet of water to farm sites by lifting water 138 feet. The irrigation system types and their corresponding acreages were as follows: hand move, 10,000 acres; solid set, 10,000 acres; side roll, 5,300 acres: drip, 300 acres; big gun, 200 acres: and center pivot, 200 acres.

\section{Wenatchee Entiat Chelan Subarea}

Lying in the western section of the subregion, this subarea contains three river basins -- the Wenatchee, Chelan, and Entiat Rivers -- which drain into the Columbia River. These rivers drain the eastern slopes of the Cascade Mountains in central Washington. 
Table 6. 1975 water requirements and energy consumption for irrigation in the Methow Okanogan Subarea.

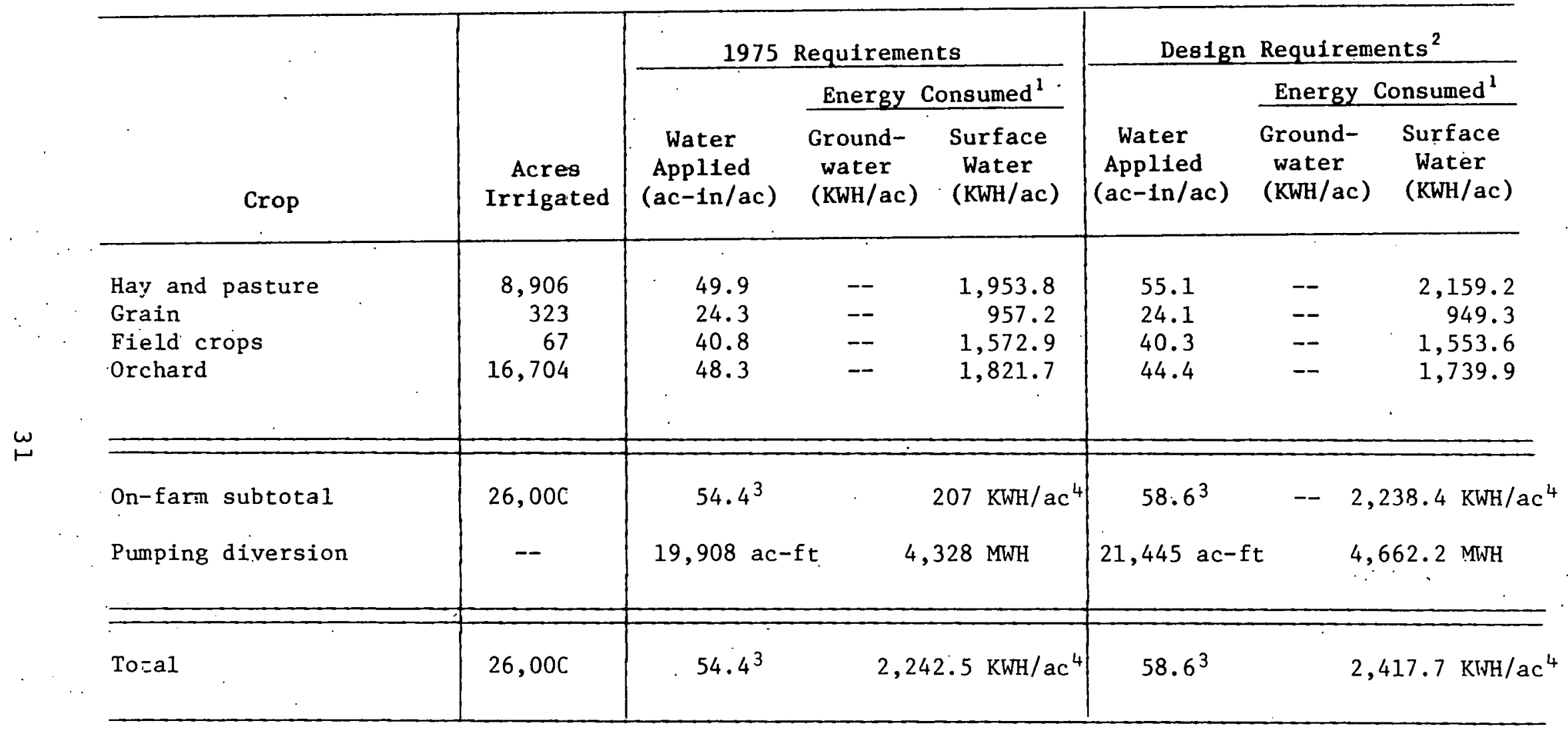

$100 \%$ of the water was supplied from surface sources with on-farm average lifts of 75 feet.

${ }^{2}$ Values represent the engineering sizing of water and energy required to provide a crop 8 years out $0 \equiv 10$.

${ }^{3}$ Average water consumed for all crops in subregion:

${ }^{4}$ Average energy required for all crops and water sources in subarea. 
Water applications and energy consumption for irrigation in this subarea are displayed in Table 7. A total of 30,000 acres was under irrigation in 1975 containing 27,860 acres (93 percent) of fruits, nuts and berries. The subarea also irrigated a limited amount of hay, pasture and small grains.

The 30,000 acres had 159,000 acre-feet of water applied and consumed 100,455 MWH of electricity in 1975. Engineering design values for 1975 were 163,750 acre-feet of water and 103,521 MWH of electricity. Two Bureau of Reclamation projects lifted 31,047 acre-feet of water 314 feet to field elevations. The remaining water requirements were obtained from individual farmer-owned pumps lifting 314 feet. Energy values reported in Table 7 have therefore incorporated the diversion pumping energy into on-farm values. Pressurized irrigation systems dominated the subarea, specifically: 18,000 acres of permanent; 9,740 acres of hand move; 1,660 acres of side roll; and 600 acres of drip. 
Table 7. 1975 water requirements and energy consumption for irrigation in the Wenatchee Entiat Chelan Subarea.

\begin{tabular}{|c|c|c|c|c|c|c|c|}
\hline \multirow[b]{3}{*}{ Crop } & \multirow[b]{3}{*}{$\begin{array}{c}\text { Acres } \\
\text { Irrigated }\end{array}$} & \multicolumn{3}{|c|}{1975 Requirements } & \multicolumn{3}{|c|}{ Design Requirements ${ }^{2}$} \\
\hline & & \multirow[b]{2}{*}{$\begin{array}{l}\text { Water } \\
\text { Applied } \\
(\text { ac-in/ac })\end{array}$} & \multicolumn{2}{|c|}{ Energy Consumed ${ }^{1}$} & \multirow[b]{2}{*}{$\begin{array}{c}\text { Water } \\
\text { Applied } \\
(\mathrm{ac}-\mathrm{in} / \mathrm{ac})\end{array}$} & \multicolumn{2}{|c|}{ Energy Consumed ${ }^{2}$} \\
\hline & & & $\begin{array}{l}\text { Ground- } \\
\text { water } \\
(\mathrm{KWH} / \mathrm{ac})\end{array}$ & $\begin{array}{l}\text { Surface } \\
\text { Water } \\
(\mathrm{KWH} / \mathrm{ac})\end{array}$ & & $\begin{array}{l}\text { Ground- } \\
\text { water } \\
\text { (KWH/ac) }\end{array}$ & $\begin{array}{l}\text { Surface } \\
\text { Water } \\
(\mathrm{KWH} / \mathrm{ac})\end{array}$ \\
\hline $\begin{array}{l}\text { Hay and pasture } \\
\text { Grain } \\
\text { Fruits, nuts and berries }\end{array}$ & $\begin{array}{r}1,980 \\
160 \\
27,860\end{array}$ & $\begin{array}{l}36.8 \\
28.0 \\
65.7\end{array}$ & $\begin{array}{l}-- \\
-- \\
--\end{array}$ & $\begin{array}{l}1,943.0 \\
1,478.4 \\
3,459.2\end{array}$ & $\begin{array}{l}45.1 \\
27.7 \\
67.2\end{array}$ & $\begin{array}{l}-- \\
-- \\
--\end{array}$ & $\begin{array}{l}2,381.3 \\
1,462.6 \\
3,538.2\end{array}$ \\
\hline $\begin{array}{l}\text { On-farm subtotal } \\
\text { Pumping diversion }\end{array}$ & $\begin{array}{c}30,000 \\
-\end{array}$ & $\begin{array}{c}63.6^{3} \\
31,047 \text { ac-ft }\end{array}$ & $\begin{array}{l}3,348 \\
30,27\end{array}$ & $\begin{array}{l}5 \mathrm{KWH} / \mathrm{ac}^{4} \\
\mathrm{MWH}^{5}\end{array}$ & $\begin{array}{c}65.5^{3} \\
31,975 \text { ac-ft }\end{array}$ & $\begin{array}{l}3,450 \\
31,178\end{array}$ & $\begin{array}{l}7 \mathrm{KWH} / \mathrm{ac}^{4} \\
\mathrm{MWH}^{5}\end{array}$ \\
\hline Total & 30,000 & $63.6^{3}$ & 3,348 & $5 \mathrm{KWH} / \mathrm{ac}^{4}$ & $65.5^{3}$ & 3,450 . & $7 \mathrm{KWH} / \mathrm{ac}^{4}$ \\
\hline
\end{tabular}

${ }^{1} 100 \%$ of the water was supplied by surface sources with average on-farm lifts of 314 feet:

${ }^{2}$ Values represent the engineering sizing of water and energy required to provide a crop 8 years out of 10.

${ }^{3}$ Average water consumed for all crops in subregion.

${ }^{4}$ Average energy required for all crops and water sources in subarea.

${ }^{5}$ This amount $\bar{o} \overline{\mathrm{I}}$ energy was already incorporated into the $\mathrm{KWH} / \mathrm{acre}$ value. 


\section{SUBREGION 3}

Yakima

The Yakima Subregion is located in south-central Washington and covers an area of approximately 6,000 square miles. The area (see Figure 4) is roughly triangular and includes Kittitas, Yakima and Benton Counties. The region contains Cascade Mountains, Wenatchee Mountains, Horse Heaven Hills and Rattlesnake Hills; topography is characterized by long hilly ridges which extend eastward from the cascades and encircle tlat valley areas.

The subregion is drained by the Yakima River and its tributaries, which include the Cle Elum, Kachess, Naches and Teanaway Rivers. The Yakima River starts near the crest of the Cascade Range, northeast of Mt. Rainier, and flows in a generally southeastern direction for approximately 180 miles to the Columbia River near Richland. The Yakima is the largest single river system which is located completely within the state of Washington.

Yakind is a major agricultural area which is dependent upon irrigation. The 1975 water and energy consumption for irrigation in the Yakima subregion is presented in Table 8. The subregion irrigated 526,000 acres, including 255,727 acres of hay and pasture. In addition to traditional crops, a wide spectrum of specialized crops was grown and irrigated.

The subregion applied 2,893,000 acre-feet of water and consumed 323,437.4 MWH of electricity to irrigate all crops in 1975. Engineering design requirements for 1975 were about 2,621,233 acre-feet of water and 294,891.6 MWH of electricity. on-farm pumping lifts averaged 250 feet for groundwater and 

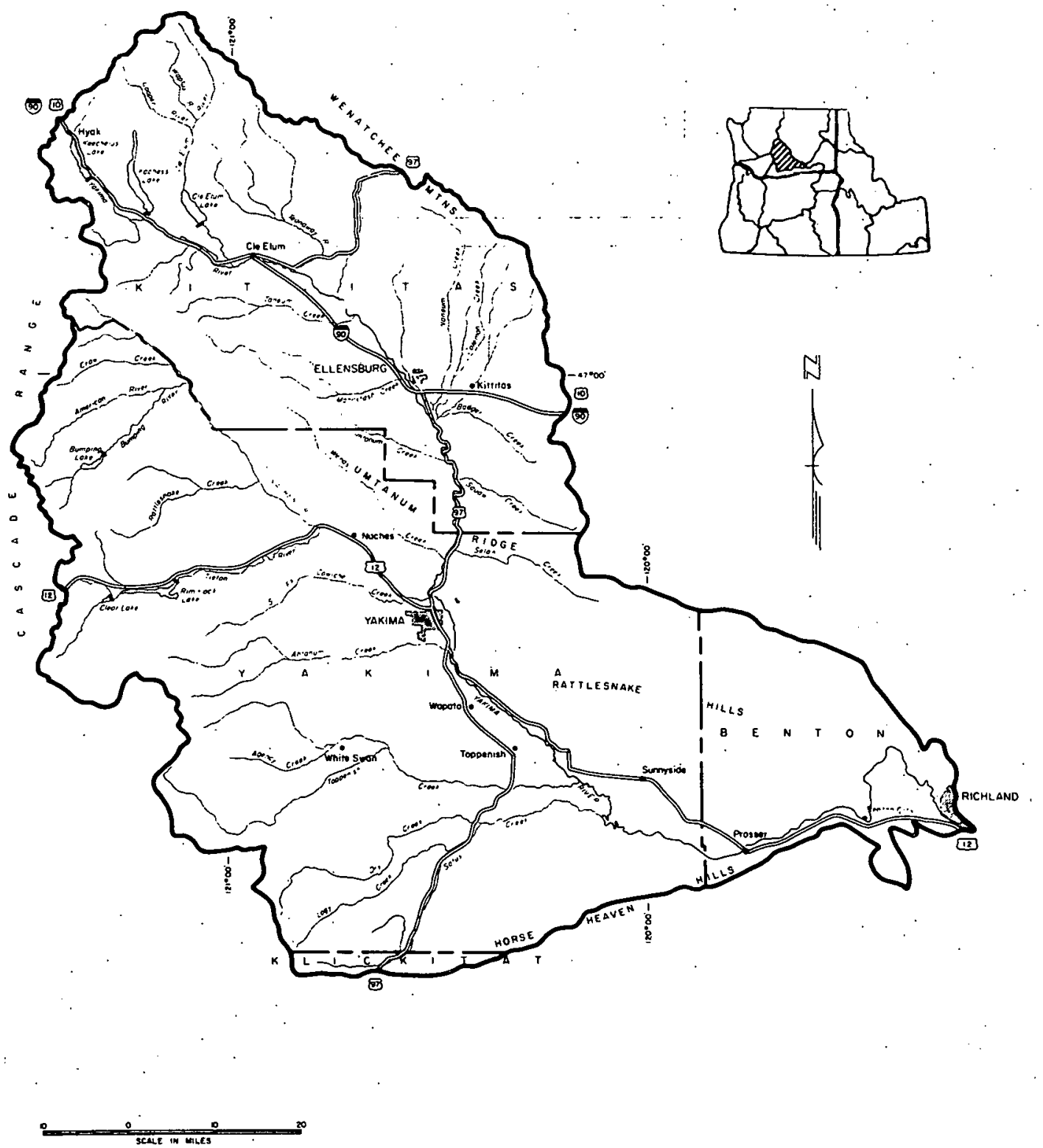

Figure 4. Map of Subregion 3 containing Yakima River Basin:

10 feet for surface sources. Of the 526,000 acres in the subregion, 398,165 acres received water from Bureau of Reclamation projects. Of the total water diverted by these projects, 125,000 acre-feet of water were lifted 200 feet to on-farm elevations. Gravity irrigation systems predominated 
Table 8. 1975 water requirements and energy consumption for irrigation ir. Yakima Subregion.

\begin{tabular}{|c|c|c|c|c|c|c|}
\hline \multirow[b]{3}{*}{ Crop } & \multirow[b]{3}{*}{$\begin{array}{c}\text { Acres } \\
\text { Irrigated }\end{array}$} & \multicolumn{2}{|c|}{1975 Requirements } & \multicolumn{3}{|c|}{ Design Requirements ${ }^{2}$} \\
\hline & & \multirow[b]{2}{*}{$\begin{array}{c}\text { Water } \\
\text { Applied } \\
(\mathrm{ac}-\mathrm{In} / \mathrm{ac})\end{array}$} & Energy Consumed ${ }^{1}$ & \multirow[b]{2}{*}{$\begin{array}{c}\text { Water } \\
\text { Applied } \\
(a c-1 a / a c)\end{array}$} & \multicolumn{2}{|c|}{ Energy Consumed ${ }^{1}$} \\
\hline & & & $\begin{array}{cc}\text { Ground- } & \text { Surface } \\
\text { water } & \text { Water } \\
(\mathrm{KWH} / \mathrm{ac}) & (\mathrm{KWH} / \mathrm{ac})\end{array}$ & & $\begin{array}{l}\text { Ground- } \\
\text { water } \\
\text { (KWH/ac) }\end{array}$ & $\begin{array}{l}\text { Surface } \\
\text { Water } \\
\text { (KWH/ac) }\end{array}$ \\
\hline $\begin{array}{l}\text { Hay and pasture } \\
\text { Grain } \\
\text { Fruits, nuts \& berries } \\
\text { Vegetables } \\
\text { Mint, hops \& dill } \\
\text { Sugar beets, sugar } \\
\text { Potatoes. } \\
\text { Legume seeds } \\
\text { Dry beans }\end{array}$ & $\begin{array}{r}255,727 \\
77,620 \\
83,516 \\
37,442 \\
4 J, 819 \\
19,083 \\
3,164 \\
-, 884 \\
I, 745\end{array}$ & $\begin{array}{l}74.8 \\
37.4 \\
69.4 \\
60.4 \\
73.4 \\
47.8 \\
57.7 \\
67.0 \\
44.3\end{array}$ & $\begin{array}{lr}3,627.6 & 246.4 \\
1,904.4 & 122.1 \\
4,210.8 & 1,080.8 \\
3,170.0 & 315.5 \\
3,639.1 & 186.5 \\
2,432.9 & 158.6 \\
2,761.1 & 244.3 \\
4,227.6 & 1,287.7 \\
2,429.4 & 346.3\end{array}$ & $\begin{array}{l}64.7 \\
41.6 \\
64.1 \\
54.2 \\
59.7 \\
64.4 \\
44.2 \\
51.9 \\
42.4\end{array}$ & $\begin{array}{l}2,846.9 \\
1,918.2 \\
3,535.7 \\
2,580.8 \\
2,690.8 \\
2,979.8 \\
1,920.5 \\
2,971.3 \\
2,110.7\end{array}$ & $\begin{array}{l}193.4 \\
122.9 \\
907.4 \\
256.9 \\
138.0 \\
194.3 \\
169.9 \\
905.0 \\
300.9\end{array}$ \\
\hline On-farm subtotal & 526,000 & $66.0^{3}$ & $544.8 \mathrm{KWH} / \mathrm{ac}^{4}$ & $59.8^{3}$ & 497.1 & $\mathrm{KWH} / \mathrm{ac}^{4}$ \\
\hline Pumping diversion & -- & 125,000 a $e-f t$ & $36,882 \mathrm{MWH}$ & 113,258 ac-ft & 33,4 & $17 \mathrm{MWH}$ \\
\hline Total & 526,000 & $66.0^{3}$ & $614.9 \mathrm{KWH} / \mathrm{ac}^{4}$ & $59.8^{3}$ & 560.6 & $\mathrm{KWH} / \mathrm{ac}^{4}$ \\
\hline
\end{tabular}

$194.8 \%$ of the water was supplied by surface sources with average on-farm pumping lifts of 10 feet and the remaining $5.2 \%$ from groundwater with average lifts of 250 feet.

${ }^{2}$ Values represent the engineering sizing of water and energy required to provide a crop 8 years out of 10 .

${ }^{3}$ Average water consumed for ail crops in subregion."

${ }^{4}$ Average energy required for $\mathbf{a} 11$ crops and water sources in subregion. 
in this subregion, with 398,700 acres. Other systems and their acreages were as follows: 55,000 acres of permanent; 43,792 acres of side roll; 22,108 acres of hand move; 3,000 acres of solid set; 2,400 acres of center pivot; and 1,000 acres of drip. 
SUBREGION 4

Upper Snake

Subregion 4 covers approximately 80 percent of the upper Snake River drainage basin--an area of nearly 36,000 square miles. The remaining 20 percent is located in Wyoming, Nevada and Utah, which are outside of this study's region. This broad Snake River Plateau is surrounded by mountain ranges on the north, east and south. The Snake River originates in Yellowstone National Park and flows more than 500 miles before leaving the subregion at king Hill, Idaho. The river's major tributaries include Buffalo Fork, Hoback, Gros Ventre, Salt, Teton, Greys, Henrys Fork, Blackfoot, Portneuf and Big Wood Rivers.

This subregion, shown in Figure 5 , is partitioned into the following six subareas: West Side, Neely Milner, Northern Streams, Heise Neely, Henrys Fork and South Fork. All subareas in this subregion contained irrigated crops which totaled 2,542,700 acres--the greatest irrigated acreage of all subregions. In fact, one subarea--Heise Neely--irrigated over 800,000 acres.

Approximately $6,839,114$ acre-feet of water were applied and $1,490,771.4 \mathrm{MWH}$ of electricity were used in the subregion for irrigation in 1975. Corresponding engineering design requirements were $7,666,844$ acre-feet of water and $1,660,249.3 \mathrm{MWH}$ of electricity.

Over $1,553,300$ acres in the subregion were irrigated with gravity systems. The remaining irrigated acreages were partitioned among the following systems: 520,191 acres of hand move; 262,649 acres of side roll; 163,660 acres of center pivot; and 42,900 acres of solid set. 


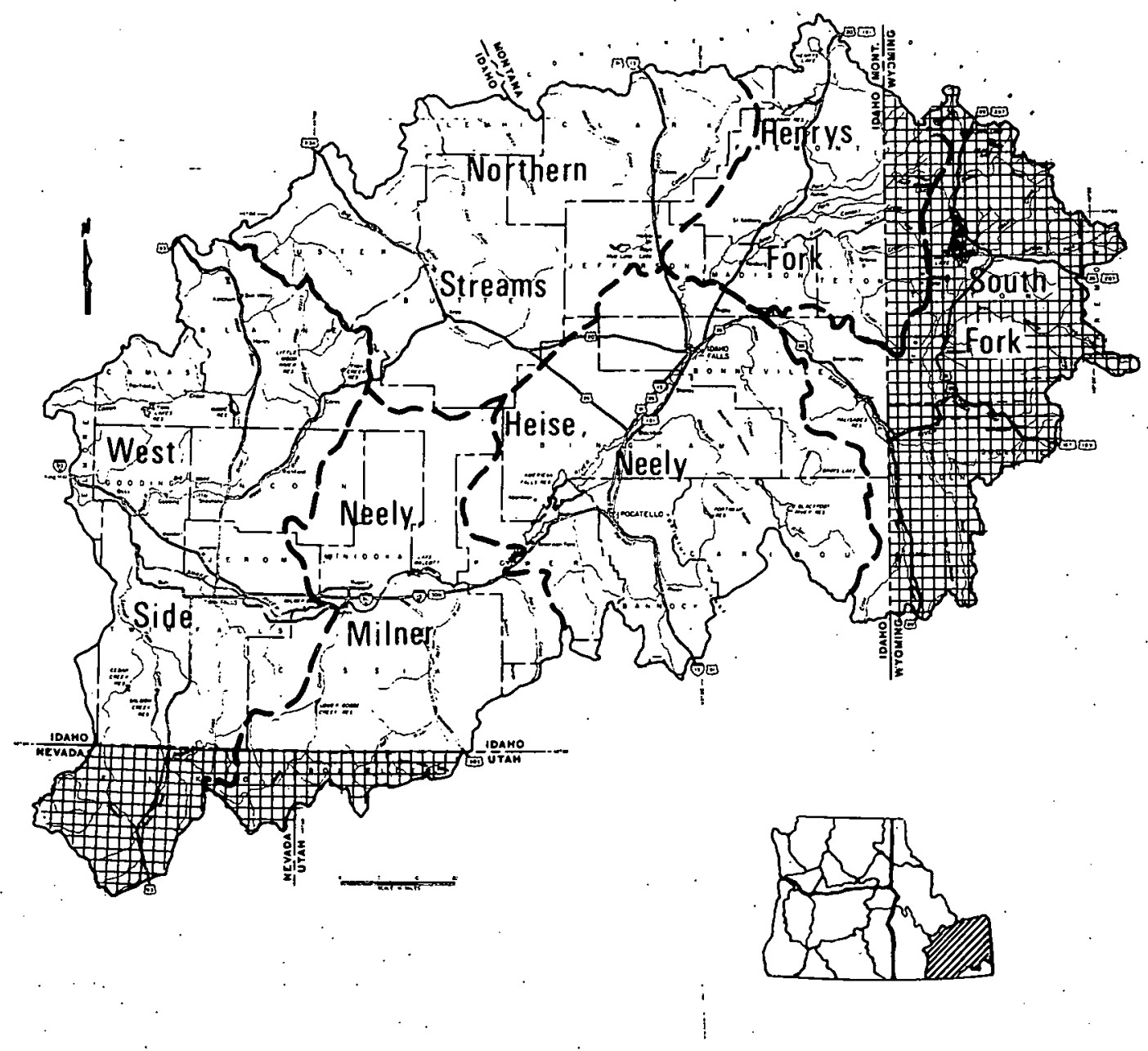

Figure 5. Map of subregion 4 containing West Si.de, Neely Milner, Northern Streams, Heise Neely, Henrys Fork and South Fork Subareas.

\section{West Side Subarea}

The West Side Subarea is found in the western corner of the subregion and includes the tributary drainage area into the Snake River between Milner Dam and King Hill. The majority of Twin Falls,.. Gooding, Blaine, Jerome, Lincoln, 
and Camas counties are contained in this subarea; the western edge of Elmore County and the eastern corner of Cassia county are also included. Approximately 17 percent of the subarea is located in northern Nevada and is not applicable to this study.

Table 9 lists the 1975 energy and water requirements for irrigation in West Side Subarea. A total of 694,000 acres was under irrigation. Hay and pasture were the largest irrigated acreage with 317,077 acres. In addition, major acreages of dried beans and peas $(133,610$ acres $)$, small grains $(130,649$ acres), potatoes $(40,500$ acres $)$, field corn $(30,528$ acres $)$, sugar beets $(23,510$ acres $)$, and vegetable seeds $(15,112$ acres $)$.

The 694,000 acres required application of 2,006,817 acre-feet of water while consuming 191,311.2 MWH of electricity. Engineering design requirements were 2,267,067 acre-feet of water and 216,215.0 MWH of electricity. Surface sources supplied the predominant (87.5 percent) amount of water to this subarea; on-farm pumping lifts averaged only 6 feet. The remaining 11.5 percent of the water was obtained from groundwater with 200 feet average lifts. Lastly, this subarea contained both Bureau of Reclamation and private pumping installations.

Gravity systems irrigated the major portion with 524,000 acres. In addition, the subarea contained 53,400 acres of center pivot, 56,600. acres of hand move, 37,200 acres of side roll, and 22,800 acres of solid set.

\section{Neely Milner Subarea}

This subarea includes the region adjacent to the snake River between American Falls and Milner Dam. The major 
Table 9. 1975 water requirements and energy consumption for irrigation in West Side Subarea.

\begin{tabular}{|c|c|c|c|c|c|c|c|}
\hline \multirow[b]{3}{*}{ Crop } & \multirow[b]{3}{*}{$\begin{array}{c}\text { Acres } \\
\text { Irrigated }\end{array}$} & \multicolumn{3}{|c|}{1975 Requirements } & \multicolumn{3}{|c|}{ Design Requirements ${ }^{2}$} \\
\hline & & \multirow[b]{2}{*}{$\begin{array}{l}\text { Water } \\
\text { Applied } \\
(a c-1 n / a c)\end{array}$} & \multicolumn{2}{|c|}{ Energy Consumed ${ }^{1}$} & \multirow[b]{2}{*}{$\begin{array}{c}\text { Water } \\
\text { Applied } \\
(\mathrm{ac}-1 \mathrm{n} / \mathrm{ac})\end{array}$} & \multicolumn{2}{|c|}{ Energy Consumed ${ }^{1}$} \\
\hline & & & $\begin{array}{l}\text { Ground- } \\
\text { water } \\
(\mathrm{KWH} / \mathrm{ac})\end{array}$ & $\begin{array}{l}\text { Surface } \\
\text { Water } \\
\text { (KWH/ac) }\end{array}$ & & $\begin{array}{l}\text { Ground- } \\
\text { water } \\
\text { (KWH/ac) }\end{array}$ & $\begin{array}{l}\text { Surface } \\
\text { Water } \\
\text { (KWH/ac) }\end{array}$ \\
\hline $\begin{array}{l}\text { Hay and pastur } \\
\text { Field corn } \\
\text { Dry beans and peas } \\
\text { Legume seed } \\
\text { Vegetable seed } \\
\text { Fruit, nuts and berries } \\
\text { Potatoes } \\
\text { Sugar beets, sugar } \\
\text { Grain }\end{array}$ & $\begin{array}{r}317,, 577 \\
30,528 \\
133,610 \\
2,773 \\
15,112 \\
241 \\
40,500 \\
23,510 \\
130,649\end{array}$ & $\begin{array}{l}40.0 \\
29.6 \\
31.3 \\
37.4 \\
22.0 \\
29.4 \\
31.6 \\
41.6 \\
27.8\end{array}$ & $\begin{array}{c}1,424.4 \\
1,067.3 \\
1,045.2 \\
-- \\
-- \\
1,351.8 \\
1,446.0 \\
1,520.8 \\
1,010.8\end{array}$ & $\begin{array}{r}135.1 \\
180.0 \\
56.4 \\
0.0 \\
0.0 \\
613.1 \\
606.6 \\
226.3 \\
153.0\end{array}$ & $\begin{array}{l}45.2 \\
33.4 \\
35.4 \\
42.2 \\
24.9 \\
33.2 \\
35.7 \\
47.0 \\
31.4\end{array}$ & $\begin{array}{c}1,609.6 \\
1,206.0 \\
1,181.1 \\
-- \\
-- \\
1,527.6 \\
1,634.0 \\
1,715.8 \\
1,142.2\end{array}$ & $\begin{array}{r}152.7 \\
203.5 \\
63.7 \\
. \quad 0.0 \\
0 \quad 0.0 \\
692.8 \\
6 \quad 685.5 \\
255.7 \\
173.0\end{array}$ \\
\hline $\begin{array}{l}\text { On-farm subtotal } \\
\text { Pumping diversion }\end{array}$ & $\begin{array}{c}694,000 \\
--\end{array}$ & $\begin{array}{r}34.7^{3} \\
105,019\end{array}$ & $\begin{array}{r}283.1 \\
\text { c-ft } \quad 58,37\end{array}$ & $\begin{array}{l}\mathrm{KWH} / \mathrm{ac}^{4} \\
8.5 \mathrm{MWH}\end{array}$ & $\begin{array}{c}39.2^{3} \\
118,671 \mathrm{ac}-\mathrm{ft}\end{array}$ & $\begin{array}{r}319.9 \\
+\quad 65,967\end{array}$ & $\begin{array}{l}\mathrm{KWH} / \mathrm{ac}^{4} \\
7.8 \mathrm{MWH}\end{array}$ \\
\hline Total & 694,000 & $34.7^{3}$ & 367.2 & $\mathrm{KWH} / \mathrm{ac}^{4}$ & $39.2^{3}$ & $415.0 \mathrm{I}$ & $\mathrm{KWH} / \mathrm{ac}^{4}$ \\
\hline
\end{tabular}

\footnotetext{
$137.5 \%$ of the water was supplied by surface sources with average on-farm pumping lifts of 6 feet and the remaining $12.5 \%$ from groundwater with average lifts of 200 feet.

2 values represent the engineerirg sizing of water and energy required to provide a crop 8 years sut of 10 .

3 Average water consumed for all crops in subregion.

${ }^{4}$ Average energy required for all crops and water sources in subarea.
} 
tributaries are Raft River and Goose Creek, located in the southern portion of the subarea. Neely Milner is composed of low mountains and broad valleys with establishedirrigated agriculture adjacent to the snake River. Most of the land to the north of the Snake River is covered with lava beds. The area includes most of Cassia and Minidoka Counties and a portion of Blaine and Power Counties. Approximately 17.4 percent of this subarea is located in northern Utah and Nevada and is not included in this study.

The 1975 energy consumption and water requirements for irriqation in the Neely. Milner subarea are listed in Table 10. The subarea irrigated 521,000 acres. Predominant irrigated crops were hay and pasture with 200,948 acres; small grains on 156,480 acres; potatoes irrigating 54,000 acres; dried beans and peas with 47,580 acres; and 46,650 acres of sugar beets.

Gravity systems with 328,500 acres supplied water to 63 percent of the total irrigated acreage. Sprinkler systems irrigated the following acreages: 106,500 acres of hand move; 37,500 acres of center pivot; 28,750 acres of stde roll; and 19,750 acres of solid set.

Approximately $1,558,658$ acre-feet of water were applied and $481,820.8 \mathrm{MWH}$ of electrlclty were used tu ifliyale lie 521,000 dises. Engineering design requirements for this corresponding period were 1,667,200 acre-feet of water and 515,581.6 MWH of electricity. only 32.2 porcent of the irrigation water was supplied by surface sources (with average on-farm lifts of 10 feet). Groundwater, with average lifts of 250 feet, supplied 66.8 percent of the total water to the subarea. In addition, 50.4 percent of gravity system water was obtained from wells. 
Table 10. 1975 water requirements and energy consumption for irrigation in Neely Milner Subarea.

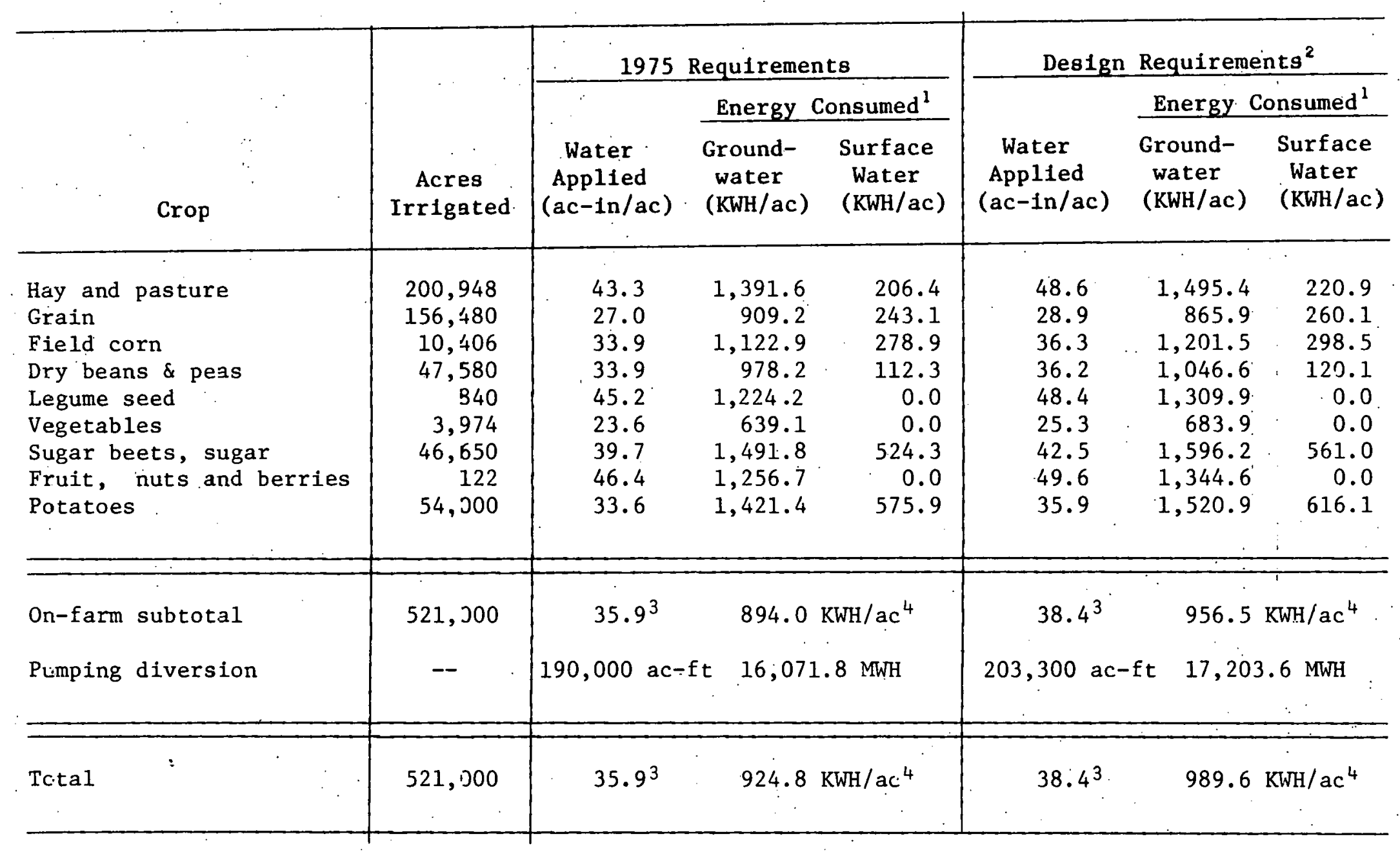

${ }^{1} 32.2 \%$ of the water was supplied by surface sources with average on-farm pumping 1ifts of 10 feet and the remaining $66.8 \%$ from groundwater with average lifts of 250 feet.

2 values represent the engineering sizing of water and energy required to provide a crop 8 .years out of 10 .

${ }^{3}$ Average water consumed for all crops in subregion.

${ }^{4}$ Average energy required for all crops and water sources in subarea. 


\section{Northern Streams Subarea}

Northern Streams Subarea is located in the northcentral portion of the subregion. The drainage area includes Big Lost River Basin, Little Lost River Basin and several creeks. Almost all of Butte and Clark Counties are contained in this subarea; parts of Custer, Lemhi and Jefferson Counties are also located here. The northern portion of the area contains mountain ranges with broad valleys, while the western section has tree-covered mountains; the southeastern portion contains desert rangelands with lava flows. Many small streams, which originate in the mountains, sink into the lava beds of the snake Plain Aquifer.

Table 11 contains the 1975 water and energy requirements for the Northern streams subarea. The subarea contained 256,400 irrigated acres in 1975. Hay and pasture were the predominant crops with 197,539 irrigated acres. Small grains and potatoes were also major irrigated crops with 47,584 and 10,915 acres, respectively.

Gravity systems irrigated 70 percent of the irrigated acreage $(179,400$ acres $)$. Hand move was also a major system with 61,000 acres (24 percent of total 1rrigated acreage). side roll and center pivot covered the remaining acreage with 10,000 and 6,000 acres, respectively.

Approximately 658,093 acre-feet of water were applied and $180,249.2$ MWH of electricity were consumed on the 256,400 acres in 1975. Corresponding engineering design requirements for 1975 were 715,783 acre-feet of water and $196,479.3 \mathrm{MWH}$ of electricity. Groundwater, with 200 feet average lifts, supplied 56.7 percent of the irrigation water; the remaining 43.3 percent was obtained from surface sources with average on-farm lifts of 10 feet. 
Table 11. 1975 water requirements and energy consumption for irrigation in the Northern Streams Subarea.

\begin{tabular}{|c|c|c|c|c|c|c|c|}
\hline \multirow[b]{3}{*}{ Crop } & \multirow[b]{3}{*}{$\begin{array}{c}\text { Acres } \\
\text { Irrigated }\end{array}$} & \multicolumn{3}{|c|}{1975 Requirements } & \multicolumn{3}{|c|}{ Design Requirements ${ }^{2}$} \\
\hline & & \multirow{2}{*}{$\begin{array}{l}\text { Water } \\
\text { Applited } \\
(a c-i n / a c)\end{array}$} & \multicolumn{2}{|c|}{ Energy Consumed ${ }^{1}$} & \multirow[b]{2}{*}{$\begin{array}{c}\text { Water } \\
\text { Applied } \\
(a c-i n / a c)\end{array}$} & \multicolumn{2}{|c|}{ Energy Consumed ${ }^{1}$} \\
\hline & & & $\begin{array}{l}\text { Ground- } \\
\text { water } \\
(\mathrm{KWH} / \mathrm{ac})\end{array}$ & $\begin{array}{l}\text { Surface } \\
\text { Water } \\
\text { (KWH/ac) }\end{array}$ & & $\begin{array}{l}\text { Ground- } \\
\text { water } \\
(\mathrm{KWH} / \mathrm{ac})\end{array}$ & $\begin{array}{l}\text { Surface } \\
\text { Water } \\
\text { (KWH/ac) }\end{array}$ \\
\hline $\begin{array}{l}\text { Hay \& pasture } \\
\text { Grain } \\
\text { Field corn } \\
\text { Pozatoes } \\
\text { Fruit, nuts, berries }\end{array}$ & $\begin{array}{r}197,539 \\
47,584 \\
360 \\
1 C, 915 \\
2\end{array}$ & $\begin{array}{l}32.2 \\
25.9 \\
30.4 \\
24.4 \\
34.0\end{array}$ & $\begin{array}{r}1,096.4 \\
938.7 \\
807.2 \\
1,169.3 \\
902.8\end{array}$ & $\begin{array}{r}189.6 \\
283.6 \\
0.0 \\
528.4 \\
0.0\end{array}$ & $\begin{array}{l}35.2 \\
28.2 \\
33.1 \\
26.6 \\
37.1\end{array}$ & $\begin{array}{r}1,195.1 \\
1,023.2 \\
879.8 \\
1,274.5 \\
984.0\end{array}$ & $\begin{array}{r}206.6 \\
309.1 \\
0.0 \\
576.0 \\
0.0\end{array}$ \\
\hline & & & & & & & \\
\hline On-farm subtotél & 256,400 & $30.8^{3}$ & 703.0 & $\mathrm{KWH} / \mathrm{ac}^{4}$ & $33.5^{3}$ & 766.3 & $\mathrm{KWH} / \mathrm{ac}^{4}$ \\
\hline Punping diversion & -- & -- & - & - & -- & & -- \\
\hline Total & 256,400 & $30 \cdot 8^{4}$ & 703.0 & $\mathrm{KWH} / \mathrm{ac}^{4}$ & $33.5^{3}$ & 766.3 & $\mathrm{KWH} / \mathrm{ac}^{4}$ \\
\hline
\end{tabular}

${ }^{1} 43.3 \%$ of the water was supplied by surface sources with average on-farm pumping lifts of $10 \mathrm{feet}$ and the remaining $56.7 \%$ from groundwater with average lifts of 200 feet.

${ }^{2}$ Values represent the engineering sizing of water and energy required to provide a crop 8 years out of 10.

${ }^{3}$ Average water consumed for all crops in subregion.

${ }^{4}$ Average energy required for all crops and water. sources in subarea. 


\section{Heise Neely Subarea}

This subarea is located in the south-central portion of the subregion with Bingham, Bonneville, Bannock and Caribou Counties containing most of the area. The southern half of the subarea contains high, rolling hills and broad valley bottoms. Valleys in the eastern portion are excellent winter wildlife habitat; the western section is highly developed for irrigation but the western edge is lava beds and desert rangelands. The northwestern half contains a large irrigated acreage adjacent to the snake River.

In 1975, Heise Neely Subarea had 2,117,588 acre-feet of water applied and used 530,324.6 MWH of electricity. Table 12 contains, for each major crop, the water and energy requirements in 1975 in this subarea, which contained 806,700 irrigated ácres.

A variety of crops was irrigated; smali grain, hay and pasture, and potatoes (with $343,398,219,715$, and 137,000 acres, respectively) contained the major irrigated acreages. In addition, various acreages of sugar beets, field corn, dried beans and peas, legume seed, fruits and nuts, and vegetables were irrigated in 1975.

Several lyies of iritigation systems were employed in the subarea. The systems and their corresponding acreages were as follows: 378,700 acres of gravity; 203,952 acres of hand move; 170,498 acres of side roll; 53,200 acres of center pivot; and 350 acres of solid set.

Surface sources, with average on-farm lifts of 10 feet, supplied 61.2 percent of the water to the subarea. The remaining 38.8 percent was obtained from groundwater with 
Table 12. 1975 water requirements and energy consumption for irrigation in Heise Neely Subarea.

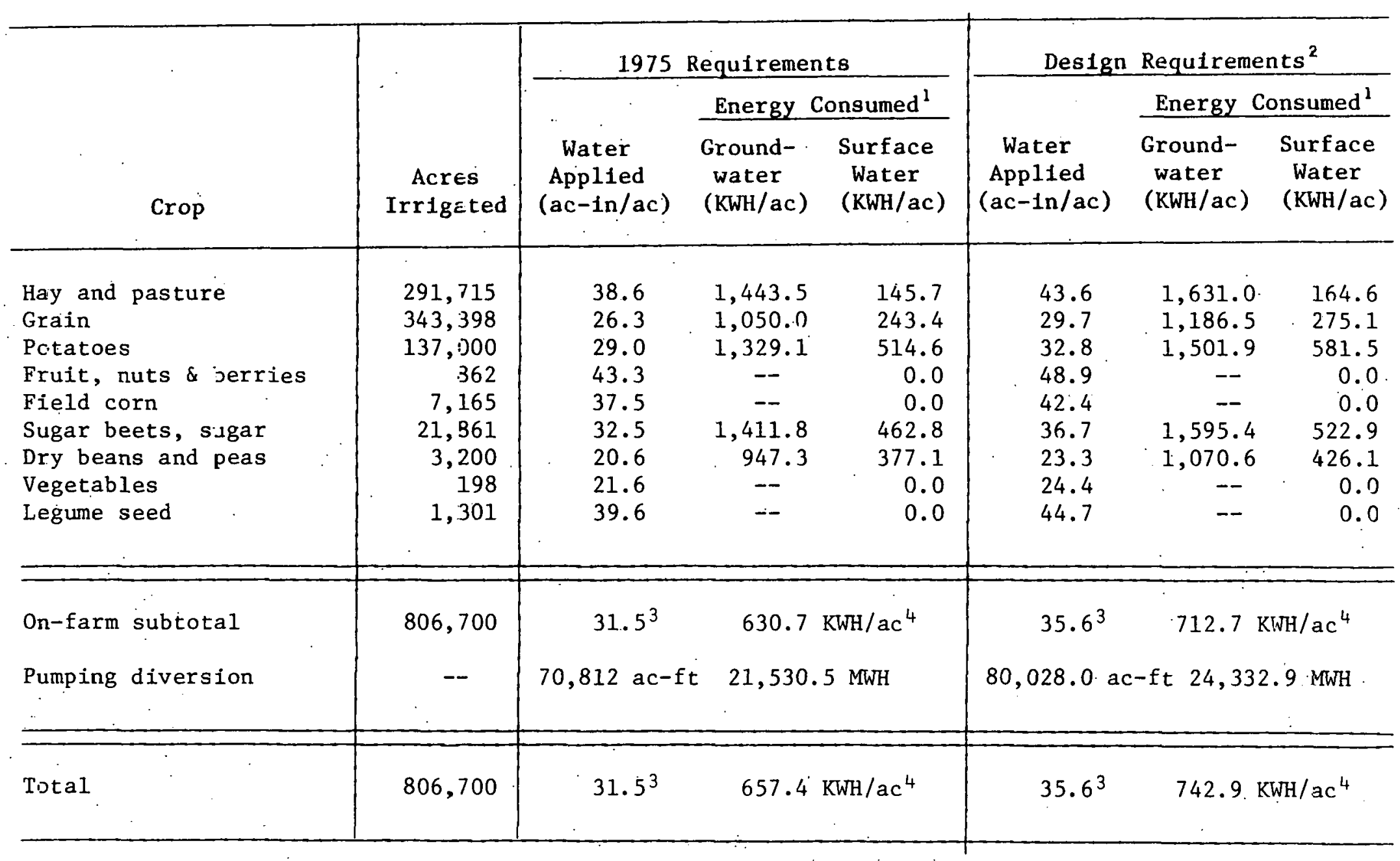

${ }^{1} 61.2 \%$ of the water was supplied by. surface sources with average on-farm pumping 1 ifts of 10 feet and the remaining 38.8 from groundwater with average lifts of $30 n$ feet.

${ }^{2}$ Values represent the engineering sizing of water and energy required to provide a crop 8 years out of 10 .

${ }^{3}$ Average water corsumed for all crops in subregion.

${ }^{4}$ Average energy $r \in q u i r e d$ for al- crops and water sources in subarea. 
280 feet average pumping lifts. A Bureau of Reclamation project delivered 389,752 acre-feet of water with average lifts of 193 feet. Lastly, engineering design requirements for this subarea were 2,393,210 acre-feet of water and $599,297.4$ MWH of electricity.

\section{Henrys Fork Subarea}

Henrys Fork Subarea covers the northeastern corner of the subregion and contains Fremont, Madison and Teton Counties in.Idaho. This subarea is near Yellowstone and Grand Teton National Parks and has scenic mountains in the eastern and northern sections with broad irrigated valley bottoms and rolling upland plains in the central and southwestern portions. Approximately 20 percent of the subarea is located in wyoming and is not included in this study.

Table 13 lists the 1975 energy and water data for Henrys Fork Subarea. A total of 249,500 acres was irrigated in the subarea with hay and pasture accounting for 43 percent $(106,897$ acres) of total. In addition, 94,015 acres of small grains and 47,710 acres of potatoes were under irrigation.

Over 50 percent of the irrigation was obtained from gravity systems with 136,500 acres. The remaining acreage was collectively irrigated with 85,880 acres of hand move, 13,560 acres of. side roll, and 13,560 acres of center pivot systems.

The 249,500 acres had 474,050 acre-feet of water applied and used 103,168.3 MWH of electricity. Engineering design requirements for the same period were 594,642 acre-feet of water and $127,868.8 \mathrm{MWH}$ of electricity. Of the total water 
Table 13. 1975 water requirements and energy consumption for irrigation in Henry's Fork Subarea.

\begin{tabular}{|c|c|c|c|c|c|c|c|}
\hline \multirow[b]{3}{*}{ Crop } & \multirow[b]{3}{*}{$\begin{array}{c}\text { Acres } \\
\text { Irrtgated }\end{array}$} & \multicolumn{3}{|c|}{1975 Requirements } & \multicolumn{3}{|c|}{ Des1gn Requirements ${ }^{2}$} \\
\hline & & \multirow[b]{2}{*}{$\begin{array}{c}\text { Water } \\
\text { Applied } \\
(\mathrm{ac}-1 \mathrm{n} / \mathrm{ac})\end{array}$} & \multicolumn{2}{|c|}{ Energy Consumed ${ }^{\prime}$} & \multirow[b]{2}{*}{$\begin{array}{c}\text { Water } \\
\text { Applied } \\
(\mathrm{ac}-1 \mathrm{n} / \mathrm{ac})\end{array}$} & \multicolumn{2}{|c|}{ Energy Consumed ${ }^{1}$} \\
\hline & & & $\begin{array}{l}\text { Ground- } \\
\text { water } \\
(\mathrm{KWH} / \mathrm{ac})\end{array}$ & $\begin{array}{l}\text { Surface } \\
\text { Water } \\
\text { (KWH/ac) }\end{array}$ & & $\begin{array}{l}\text { Ground- } \\
\text { water } \\
\text { (KWH/ac) }\end{array}$ & $\begin{array}{c}\text { Surface } \\
\text { Water } \\
\text { (KWH/ac) }\end{array}$ \\
\hline $\begin{array}{l}\text { Hay and pasture } \\
\text { Grain } \\
\text { Potatoes } \\
\text { Field corn } \\
\text { Fruit, nuts \& berries } \\
\text { Vegetables }\end{array}$ & $\begin{array}{r}106,897 \\
94,015 \\
47.710 \\
863 \\
12 \\
3\end{array}$ & $\begin{array}{l}24.1 \\
22.5 \\
20.5 \\
22.2 \\
33.3 \\
13.3\end{array}$ & $\begin{array}{l}1,531.2 \\
1,583.4 \\
1,546.2 \\
-- \\
-- \\
--\end{array}$ & $\begin{array}{r}39.5 \\
-- \\
189.0 \\
0.0 \\
0.0 \\
0.0\end{array}$ & $\begin{array}{l}31.1 \\
27.5 \\
25.4 \\
28.2 \\
40.0 \\
17.8\end{array}$ & $\begin{array}{c}1,975.9 \\
1,935.3 \\
1,915.7 \\
-- \\
-- \\
--\end{array}$ & $\begin{array}{r}51.0 \\
179.6 \\
234.3 \\
0.0 \\
0.0 \\
0.0\end{array}$ \\
\hline On-farm subtotal & 249,500 & $22.8^{3}$ & 413.5 & $\mathrm{KWH} / \mathrm{ac}^{4}$ & $28.6^{3}$ & 512.5 & $\mathrm{KWH} / \mathrm{ac}^{4}$ \\
\hline Pumping diversion & -- & -- & - & - & -- & -- & \\
\hline Total & 249,500 & $22.8^{3}$ & 413.5 & $\mathrm{KWH} / \mathrm{ac}^{4}$ & $28.6^{3}$ & 512.5 & $\mathrm{KWH} / \mathrm{ac}^{4}$ \\
\hline
\end{tabular}

${ }^{1} 79 \%$ of the water was supplied by surface sources with average on-farm pumping lifts of 15 feet and the remaining $21 \%$ from groundwater with average lifts of 300 feet.

${ }^{2}$ Values represent the engineering sizing of water and energy required to provide a crop 8 years out of 10 .

${ }^{3}$ Average water consumed for all crops in subregion.

${ }^{4}$ Average energy required for all crops and water sources in subarea. 
supplied for irrigation, 21 percent was obtained from groundwater with average lifts of 300 feet. The remaining 79 percent was supplied by surface sources with average on-farm pumping lifts of 15 feet. The subarea did not contain large diversion pumping plants but did include surface diversions managed by the Bureau of Reclamation.

\section{South Fork Subarea}

Eighty-one percent of the South Fork Subarea is located in Wyoming and, therefore, not included in this study. The study does include eastern portions of Bonneville and Caribou Counties, Idaho. The total subarea contains part of Yellowstone National Park and all of Grand Teton National Park.

South Fork's irrigation water and energy requirements for 1975 are listed in Table 14. The subarea contained 15,100 irrigated acres with hay and pasture accounting for 79 percent $(12,000$ acres) of the total. In addition, 3,100 acres of smail yrains were irrigated.

Only. three major types of irrigation systems were employed in the subarea. Gravity systems irrigated 6,200 duree, hand move supplied water to 6,259 acres and side roll covered 2,641 acres.

The 15,100 acres had 23,908 acre-feet of water applied and consumed 3,897.3 MWH of electricity. corresponding engineering design requirements were 28,942 acre-feet of water and $4,807.8 \mathrm{MWH}$ of electricity. In addition, 87.3 percent of the water was supplied from surface sources with average 
Table 14. 1975 water requirement and energy consumption for irrigation in South Fork Subarea.

\begin{tabular}{|c|c|c|c|c|c|c|c|}
\hline \multirow[b]{3}{*}{ Crop } & \multirow[b]{3}{*}{$\begin{array}{c}\text { Acres } \\
\text { Irrigated }\end{array}$} & \multicolumn{3}{|c|}{1975 Requirements } & \multicolumn{3}{|c|}{ Design Requirements ${ }^{2}$} \\
\hline & & \multirow[b]{2}{*}{$\begin{array}{l}\text { Water } \\
\text { Applied } \\
(\mathrm{ac}-1 \mathrm{n} / \mathrm{ac})\end{array}$} & \multicolumn{2}{|c|}{ Energy Consumed ${ }^{l}$} & \multirow[b]{2}{*}{$\begin{array}{c}\text { Water } \\
\text { Applied } \\
(a c-i n / a c)\end{array}$} & \multicolumn{2}{|c|}{ Energy Consumed ${ }^{1}$} \\
\hline & & & $\begin{array}{l}\text { Ground- } \\
\text { water } \\
\text { (KWH/ac) }\end{array}$ & $\begin{array}{c}\text { Surface } \\
\text { Water } \\
\text { (KWH/ac) }\end{array}$ & & $\begin{array}{l}\text { Ground- } \\
\text { water } \\
(\mathrm{KWH} / \mathrm{ac})\end{array}$ & $\begin{array}{l}\text { Surface } \\
\text { Water } \\
(\mathrm{KWH} / \mathrm{ac})\end{array}$ \\
\hline $\begin{array}{l}\text { Hay and pasture } \\
\text { Grain }\end{array}$ & $\begin{array}{r}12,000 \\
3,100\end{array}$ & $\begin{array}{l}19.6 \\
16.7\end{array}$ & $\begin{array}{l}524.7 \\
464.6\end{array}$ & $\begin{array}{l}211.1 \\
264.8\end{array}$ & $\begin{array}{l}24.4 \\
17.7\end{array}$ & $\begin{array}{l}653.2 \\
492.5\end{array}$ & $\begin{array}{r}262.7 \\
329.6\end{array}$ \\
\hline On-farm subtotal & 15,100 & $19.0^{3}$ & 258.1 & $\mathrm{KWH} / \mathrm{ac}^{4}$ & $23.0^{3}$ & 318.4 & $\mathrm{KWH} / \mathrm{ac}^{4}$ \\
\hline Pumping diversion & -- & -- & & - & -- & -- & \\
\hline Total & 15,100 & $19.0^{3}$ & 258.1 & $\mathrm{KWH} / \mathrm{ac}^{4}$ & $23.0^{3}$ & $318.4 \mathrm{~K}$ & $\mathrm{KWH} / \mathrm{ac}^{4}$ \\
\hline
\end{tabular}

${ }^{1} 87.3 \%$ of the water was supplied by surface sources. with average on-farm pumping lifts of 15 feet and the remaining $12.7 \%$ from groundwater with average lifts of 75 feet. .

2 Values represent the engineerirg sizing of water and energy required to provide a crop 8 years out of 10 .

${ }^{3}$ Average water consumed for all crops in subregion.

4 Average energy required for all crops and water sources in subarea. 
on-farm pumping lifts of 15 feet. Remaining water was obtained from groundwater sources with average lifts of 75 feet. Lastly, this subarea does not contain large diversion pumping plants. 


\section{SUBREGION 5}

Central Snake

This subregion lies in southwestern Idaho, southeastern oregon and a small portion of northern Nevada. The area includes approximately 37,000 square miles of land with 52 percent in Idaho, 38 percent in oregon and 10 percent in Nevada. The Nevada portion is outside this study's area.

The subregion includes the drainage area along a 280-mile reach of the Snake River from King Hill, Idaho, downstream to a point below oxbow Dam on the Oregon-Idaho border. The tributaries of the Snake River in this subregion are: Burnt, Powder, Payette, Weiser, Malheur, Bruneau, Owyhee and Boise. This subregion is partitioned into the seven subareas shown in Figure 6 .

Irrigation began in the region in the 1860's coinciding with early gold discoveries. The Boise and Payette River valleys have been irrigating since 1863. By 1900, approximately 150,000 acres were under irrigation in these valleys. In 1975 the subregion contained $1,319,928$ acres with over $1,000,000$ acres under gravity irrigation. Remaining systems and their 1975 acreages were as follows: 15,810 acres of center pivot; 176,079 acres of hand move; 72,189 acres of side roll; 26,982 acres of solid set; 558 acres of permanent; and 1,494 acres of big gun.

The 1,319,928 acres had 4,443,773 acre-feet of water applied and used 500,093.4 MWH of electricity. Engineering design requirements for this same period were $4,993,265$ acre-feet of water and $650,855.4 \mathrm{MWH}$ of electricity. 


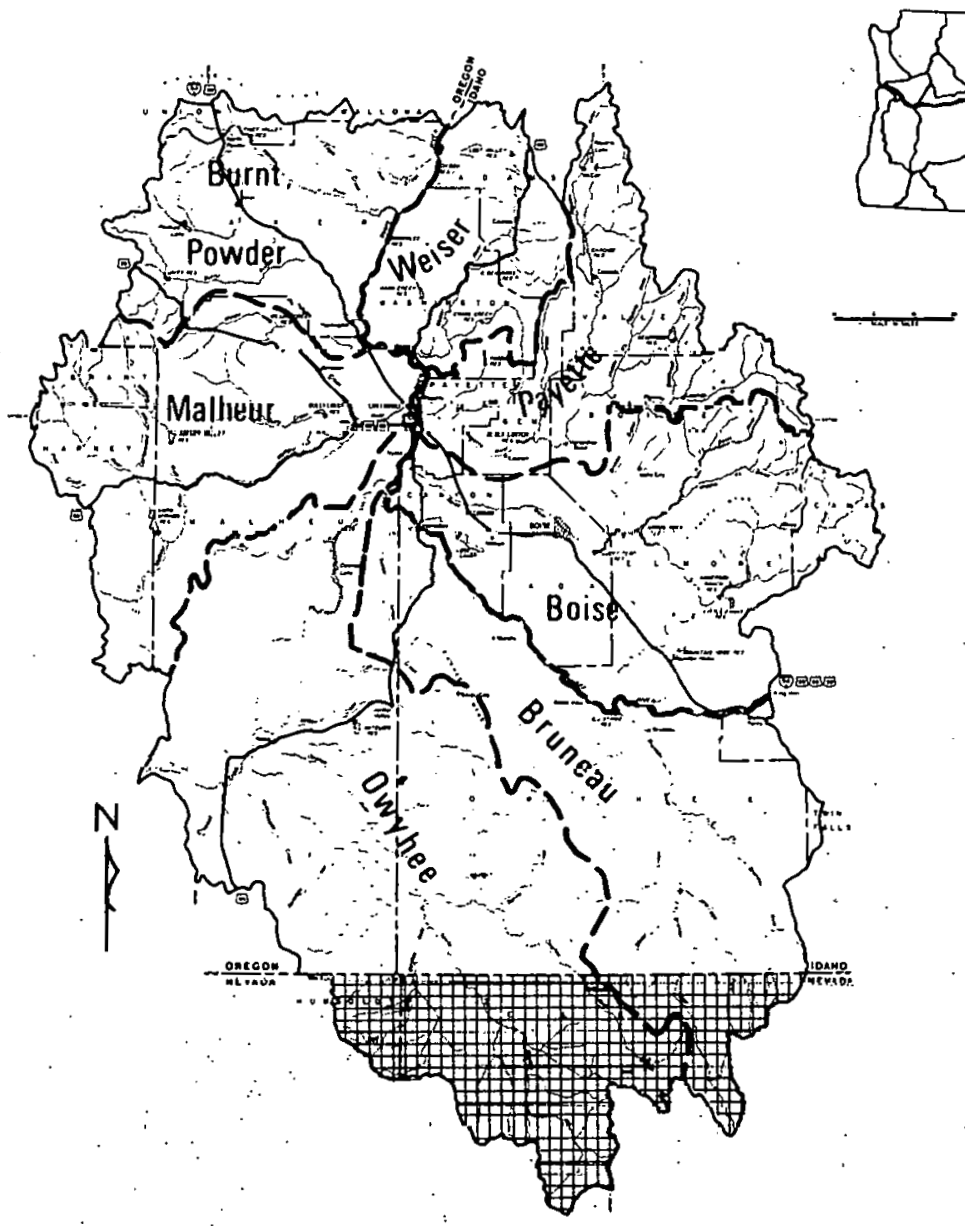

Figure 6. Map of Subregion 5 containing Burnt Powder, Malheur, Weiser, Payette, Boise, Bruneau, and Owyhee Subareas.

The major irrigated crops in the subregion were hay and pasture with approximately 793,000 acres: Large acreages of small grains, field crops, sugar beets, legume seeds and potatoes were also irrigated. 


\section{Boise Subarea}

This subarea consists of the Boise River drainage basin plus the area south and east of the snake River, including Mountain Home Plateau and Trinity Mountains. The majority of Canyon, Ada, Elmore, and Boise Counties are included in this subarea. The Boise River tributaries are Grimes Creek and several forks of Boise River.

Table 15 lists the energy and water requirements for 1975 in Boise Subarea. The subarea contained 463,282 acres. Hay and pasture accounted for 50 percent of the acreage with 232,453 acres. Large acreages of small grains, field crops, sugar beets, legume seeds, and potatoes were also irrigated.

The area had 1,640,790 acre-feet of water applied and used 229,079.4 MWH of electricity in 1975. Corresponding engineering design requirements were $1,760,472$ acre-feet of water and $249,260.1$ MWH of electricity. Pumped diversion from numerous private developments along the snake River and a Bureau of Reclamation project on the Owyhee River, Oregon, diverted 51,251 acre-feet of water with an average lift of 514 feet in 1975 .

Gravity systems irrigated 374,900 acres $(81$ percent of total). In addition, the subarea contained 53,548 acres of hand move, 16,000 acres of solid set, 13,540 acres of side roll, and 6,000 acres of center pivot.

\section{Bruneau Subarea}

The Bruneau Subarea is positioned in the southeastern corner of the subregion in Owyhee county. It includes the Bruneau River Basin and small southside Snake River tributaries, 
Table 15. 1975 water requirements and energy consumption for irrigation in Boise Subarea.

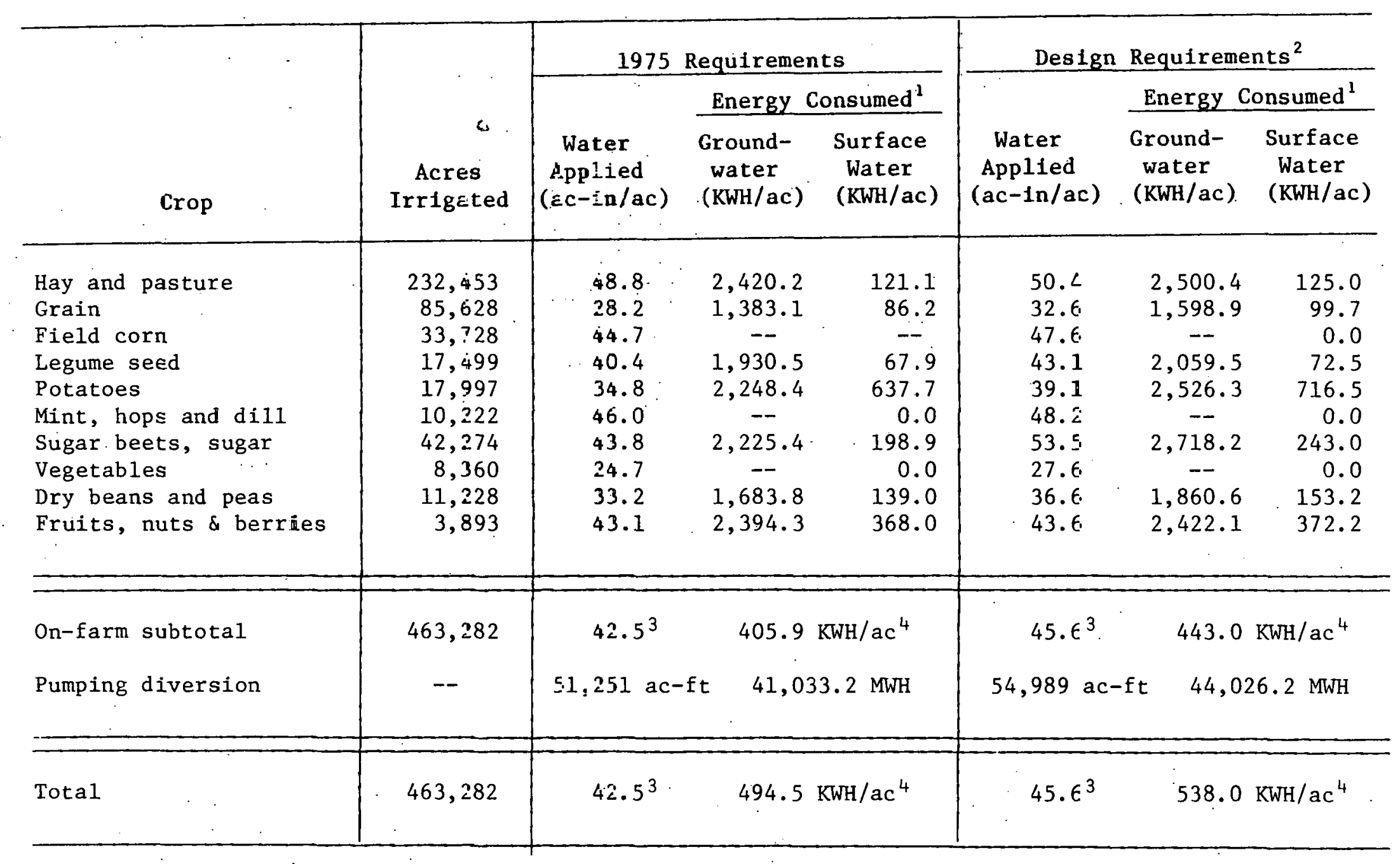

$186.3 \%$ of the water was supplied by surface sources with average on-farm pumping lifts of 0 feet and the remaining $13.7 \%$ from groundwater with average lifts of 350 feet.

${ }^{2}$ Values represent the engineering sizing of water and energy required to provide a crop 8 years out of 10 .

${ }^{3}$ Average water consumed for all crops in stkregicn.

verage energy required for all crops anc water sources in subarea. 
including Succor crcek. The area is characterized by broad, sage-covered, gently sloping regions which are dissected by deep canyons. Approximately 11 percent of the subarea is located in Nevada and is not included in this study.

Energy and water requirements for the 1975 irrigation season are listed in Table 16. A total of 229,124 acres was irrigated in this subarea. Hay and pasture were again the major irrigated crops with 137,605 acres. Large irrigated acreages of small grains, potatoes, sugar beets, dried beans and peas, field corn, and legume seed were also irrigated.

The 229,124 irrigated acres had 786,659 acre-feet of water applied and consumed 136,468.7 MWH of electricity in 1975. Corresponding engineering design requirements were 895,493 acre-feet of water and 154,613.5 MWH of electricity. Surface sources supplied" 86.4 percent of the irrigation water with average on-farm lifts of 8 feet; the remaining 13.6 percent of the water was obtained from groundwater with average lifts of 284 feet.

This area is characterized by many diversion pumping plants from the snake River which delivered water to field elevations under pressure. It also included pumped and gravity diversions from the Uwyhee River. Gravity, with 146,717 acres, was the major irrigation system. In addition, 6,378 acres of center pivot, 54,901 acres of hand move, 10,397 acres of side roll, 9,566 acres of solid set, and 1,165 acres of big gun were used in this subarea.

\section{Owyhee Subarea}

The Owyhee subarea is located in the southern section of the subregion and includes parts of Malheur County, 
Table 16. 1975 water requirements and energy consumptión for irrigation in Bruneau Subarea.

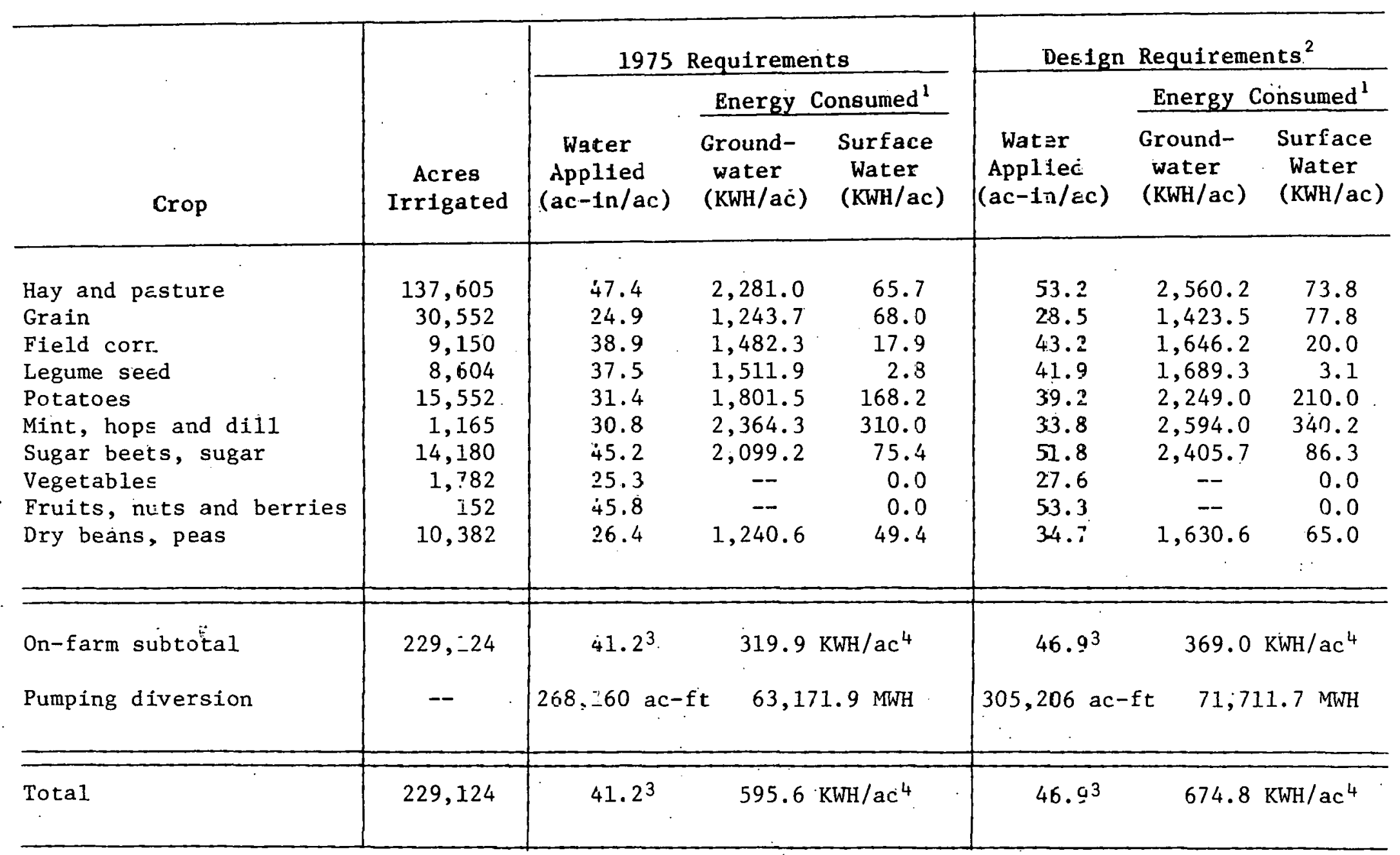

$186.4 \%$ of the water was supplied by surface sources with average on-farm pumping lifts of 8 feet and the remaining $13.6 \%$ from groundwater with average lifts of 284 feet.

2 Values represent the engineering sizing of water and energy required to proside a crop 8 years out of 10 .

3 Average water consumed for all crops in subregion.

rerage energy reqlired for all crops and water sources in subarea. 
oregon and Owyhee county, Idaho. It is characterized by a rugged, high plateau which is deeply dissected by the owyhee River and its tributaries. Approximately 25 percent of this subarea is located in northern Nevada and is not included in this study.

Table 17 presents the energy and water requirements for 1975 in the Owyhee Subarea. The subarea contained 88,776 irrigated acres with 56,712 acres in hay and pasture. In addition, 13,789 acres of small grains were irrigated. The 88,776 acres had 308,497 acre-feet of water applied and consumed $7,270.4 \mathrm{MWH}$ of electricity. Engineering design requirements for this corresponding period were 158,063 acre-feet of water and 8,436.4 MWH of electricity. Surface sources, with on-farm average pumping lifts of 15 feet, supplied 99.6 percent of the irrigation water; groundwater, with average lifts of 63 feet, supplied the remaining water. In addition, diversion pumps supplied 19,538 acre-feet of water to surface sources. of the 88,776 acres, gravity systems irrigated 82,891 acres. The remaining acreage was managed with the following pressurized systems: center pivot (125 acres), hand move $(2,635$ acres), side roll (3,000 acres), solid set ( 78 acres), and big gun (47 acres).

\section{Payette Subarea}

A wooded, mountainous region, the Payette subarea is in the northeastern corner of the subregion and contains Payette, Gem, Valley and part of Boise Counties. The payette drainage basin is dissected by large creeks and rivers which flow in long, narrow valleys. Small glacial lakes dot high mountain meadows and several manmade lakes 
Table 17. 1975 water requirements and energy consumption for irrigation in the Owyhee Subarea.

\begin{tabular}{|c|c|c|c|c|c|c|c|}
\hline \multirow[b]{3}{*}{ Crop } & \multirow[b]{3}{*}{$\begin{array}{c}\text { fucres } \\
\text { Irrigated }\end{array}$} & \multicolumn{3}{|c|}{1975 Requirements } & \multicolumn{3}{|c|}{ Des 1gn Requirements ${ }^{2}$} \\
\hline & & \multirow{2}{*}{$\begin{array}{c}\text { Water } \\
\text { Applied } \\
(\mathrm{ac}-\mathrm{in} / \mathrm{ac})\end{array}$} & \multicolumn{2}{|c|}{ Energy Consumed ${ }^{1}$} & \multirow[b]{2}{*}{$\begin{array}{c}\text { Water } \\
\text { Applied } \\
(a c-i n / a=)\end{array}$} & \multicolumn{2}{|c|}{ Energy Consumed ${ }^{l}$} \\
\hline & & & $\begin{array}{c}\text { Ground- } \\
\text { water } \\
\text { (KWH/ac) }\end{array}$ & $\begin{array}{l}\text { Surface } \\
\text { Water } \\
\text { (KWH/ac) }\end{array}$ & & $\begin{array}{l}\text { Ground- } \\
\text { water } \\
\text { (KWH/ac) }\end{array}$ & $\begin{array}{l}\text { Surface } \\
\text { Water } \\
(\mathrm{KWH} / \mathrm{ac})\end{array}$ \\
\hline $\begin{array}{l}\text { Hay \& pasture } \\
\text { Grain } \\
\text { Field corn } \\
\text { Legume seed } \\
\text { Potatoes } \\
\text { Mint hops, dill } \\
\text { Sugar beets, sugar } \\
\text { Vegetables }\end{array}$ & $\begin{array}{r}56,712 \\
-3,789 \\
3,909 \\
2,381 \\
2,998 \\
1,005 \\
4,880 \\
3,102\end{array}$ & $\begin{array}{l}46.3 \\
29.5 \\
33.0 \\
37.2 \\
36.5 \\
34.4 \\
42.6 \\
32.8\end{array}$ & $\begin{array}{r}1,086.7 \\
694.1 \\
754.8 \\
871.0 \\
870.0 \\
805.5 \\
1,011.4 \\
747.3\end{array}$ & $\begin{array}{l}52.3 \\
39.0 \\
41.1 \\
52.7 \\
70.7 \\
48.3 \\
76.0 \\
21.0\end{array}$ & $\begin{array}{l}53.7 \\
34.2 \\
38.3 \\
43.1 \\
42.4 \\
39.9 \\
49.4 \\
38.1\end{array}$ & $\begin{array}{r}1,260.6 \\
805.2 \\
875.6 \\
1,010.3 \\
1,009.3 \\
934.4 \\
1,173.2 \\
866.8\end{array}$ & $\begin{array}{l}60.6 \\
45.3 \\
47.6 \\
61.1 \\
82.0 \\
56.0 \\
88.1 \\
24.4\end{array}$ \\
\hline On-farm subtotal & $\varepsilon 8,776$ & $41.7^{3}$ & 54.3 & $\mathrm{KWH} / \mathrm{ac}{ }^{4}$ & $48.4^{3}$ & 63 & $\mathrm{D}^{\prime} \mathrm{KWH} / \mathrm{ac}{ }^{4}$ \\
\hline Pumping diversion & - & $19,538 \mathrm{ac}-\mathrm{ft}$ & $2,449.9$ & MWH & 22,677 ac-ft & 2,843 & $5 \mathrm{MWH}$ \\
\hline Total & $88,7.76$ & $41.7^{3}$ & 81.9 & $\mathrm{KWH} / \mathrm{ac}^{4}$ & $48.4^{3}$ & 95 & $0 \mathrm{KWH} / \mathrm{ac}^{4}$ \\
\hline
\end{tabular}

${ }^{1} 99.6 \%$ of the water was supplied by surface sources.with average on-farm pumping lifts of 15 feet and the remaining $0.4 \%$ from groundwater with average lifts of 63 feet.

${ }^{2}$ Values represent the engineerzng sizing of water and eviergy required to provide a crop 8 years out of 10 .

${ }^{3}$ Average water consuned for a1: crops in subregion.

${ }^{4}$ Average energy requ-red for a- 1 crops and water sources in subarea. 
are located in the lower elevation bottom lands. The waters of the Payette River are generally cool, clear, and of high quality.

Table 18 presents the 1975 irrigation energy and water consumption for the Payette Subarea: A total of 165,019 acres was irrigated in 1975. Hay and pasture once again represented the subarea's major irrigated acreage with 125,963 acres. Small grains were also irrigated on 16,770 acres; in addition, limited acreages of field corn, mint, hops, dill, legume seed, vegetables, sugar beets, fruit, nuts and potatoes were irrigated.

The 165,019 acres had 573,441 acre-feet of water applied and used 47,063.4 MWH of electricity in 1975. Engineering design requirements were 655,951 acre-feet of water and 54,060.2 MWH of electricity in 1975. All pumping was conducted by individualized farm operations without large pump diversions.

Eighty percent of the irrigated acreage in this subarea was under gravity irrigation $(131,209$ acres). The remaining 20 percent employed the following systems: 21,286 acres of hand move, 11,387 acres of side roll, 683 acres of solid set, and 454 acres of permanent.

\section{Weiser Subarea}

The Weiser drainage basin is a rolling upland and mountainous area in the northern part of the subregion. Many of the narrow valleys have strips of farmland near streams. The area includes parts of Washington and Adams counties, Idaho, which are adjacent to the oregon border. 
Table 18. 1975 waier requirements and energy consumption for irrigation in Payette Subarea.

\begin{tabular}{|c|c|c|c|c|c|c|c|}
\hline \multirow[b]{3}{*}{ Crop } & \multirow[b]{3}{*}{$\begin{array}{c}\text { Acres } \\
\text { Irrigated }\end{array}$} & \multicolumn{3}{|c|}{1975 Requirements } & \multicolumn{3}{|c|}{ Design Requirements ${ }^{2}$} \\
\hline & & \multirow[b]{2}{*}{$\begin{array}{c}\text { Water } \\
\text { Applied } \\
(a c-i n / a c)\end{array}$} & \multicolumn{2}{|c|}{ Energy Consumed ${ }^{1}$} & \multirow[b]{2}{*}{$\begin{array}{c}\text { Water } \\
\text { Applied } \\
(a c-1 n / a c)\end{array}$} & \multicolumn{2}{|c|}{ Energy Consumed ${ }^{1}$} \\
\hline & & & $\begin{array}{l}\text { Ground- } \\
\text { water } \\
\text { (KWH/ac) }\end{array}$ & $\begin{array}{l}\text { Surface } \\
\text { Water } \\
\text { (KWH/ac) }\end{array}$ & & $\begin{array}{l}\text { Ground- } \\
\text { water } \\
(\mathrm{KWH} / \mathrm{ac})\end{array}$ & $\begin{array}{l}\text { Surface } \\
\text { Water } \\
\text { (KWH/ac) }\end{array}$ \\
\hline $\begin{array}{l}\text { Hay and pasture } \\
\text { Grain } \\
\text { Field corn } \\
\text { Hops, min } \text { ind dill } \\
\text { Legume sead } \\
\text { Vegetables } \\
\text { Sugar beets, sugar } \\
\text { Fruit, nuts \& berries } \\
\text { Potatoes }\end{array}$ & $\begin{array}{r}125,963 \\
16,770 \\
2,605 \\
1,490 \\
3,029 \\
3,683 \\
4,162 \\
6,454 \\
863\end{array}$ & $\begin{array}{l}44.6 \\
23.3 \\
40.4 \\
42.7 \\
46.2 \\
23.1 \\
47.6 \\
39.3 \\
35.1\end{array}$ & $\begin{array}{c}1,654.8 \\
933.5 \\
-- \\
-- \\
-- \\
-- \\
1,694.8 \\
1,552.4 \\
1,636.7\end{array}$ & $\begin{array}{r}121.2 \\
256.8 \\
0.0 \\
0.0 \\
0.0 \\
0.0 \\
198.4 \\
402.6 \\
799.7\end{array}$ & $\begin{array}{l}50.7 \\
28.5 \\
47.5 \\
48.4 \\
52.4 \\
27.6 \\
55.2 \\
43.1 \\
38.9\end{array}$ & $\begin{array}{c}1,881.1 \\
1,145.9 \\
-- \\
-- \\
-- \\
-- \\
1,965.5 \\
1,702.6 \\
1,813.8\end{array}$ & $\begin{array}{r}137.8 \\
315.2 \\
0.0 \\
0.0 \\
0.0 \\
0.0 \\
230.1 \\
441.6 \\
886.3\end{array}$ \\
\hline E & & & & & & & \\
\hline On-farm subtotal & 165,019 & $41.7^{3}$ & 285.2 & $\mathrm{KWH} / \mathrm{ac}^{4}$ & $47.7^{3}$ & 327.6 & $\mathrm{KWH} / \mathrm{ac}^{4}$ \\
\hline Pumping diversion & -- & -- & & - & -- & & - \\
\hline Total & 165,019 & $41.7^{3}$ & 285.2 & $\mathrm{KWH} / \mathrm{ac}^{4}$ & $47.7^{3}$ & 327.6 & $\mathrm{KWH} / \mathrm{ac}^{4}$ \\
\hline
\end{tabular}

$189.1 \%$ of the water was supplied by surface sources with average on-farm pumping lifts of 45 feet and the remaining $10.9 \%$ from groundwater $\nabla i=h$ average lifts of 200 feet.

${ }^{2}$ Values represent the engineering sizing of water and energy required to provide a crop 8 years out of 10 .

${ }^{3}$ Average water consumed for all crops in subregion.

${ }^{4}$ Average energy required for all crops and water sources in subarea. 
Table 19 contains the 1975 irrigation water and energy requirements in Weiser subarea. A total of 54,305 acres was under irrigation, of which hay and pastures included 30,293 acres. Small grains were also a major crop with $12 ; 898$ irrigated acres. Limited acreages of field corn, legume seed, vegetables, potatoes and sugar beets were also irrigated.

A total of 187,805 acre-feet of water was applied and 8,091.4 MWH of electricity consumed on the 54,305 irrigated acres. Engineering design requirements were 215,862 acre-feet of water and 9,438.2 MWH of electricity for this subarea in 1975. Of the total irrigation water, 92.7 percent was supplied from surface sources with average on-farm lifts of 20 feet. The remaining 7.3 percent was obtained from groundwater with average pumping lifts of 180 feet. The area contained individualized farm pumping plants rather than large pumping diversions.

Almost all $(47,565$ acres) of the irrigated land was under gravity systems. However, hand move and side roll irrigated 5,729 and 1,011 acres, respectively.

\section{Burnt Powdcr subarea}

Burnt Powder Subarea includes the Burnt and Powder River drainage basins and lies in Baker County, Oregon. The semiarid area is composed of rolling sage-covered hills and narrow valleys with occasional expansions into broader valleys. Irrigated lands are located in several of the valleys along the Powder and Burnt Rivers. 
Table 19. 1975 water requirements and energy consumption for irrigation in the Weiser Subarea.

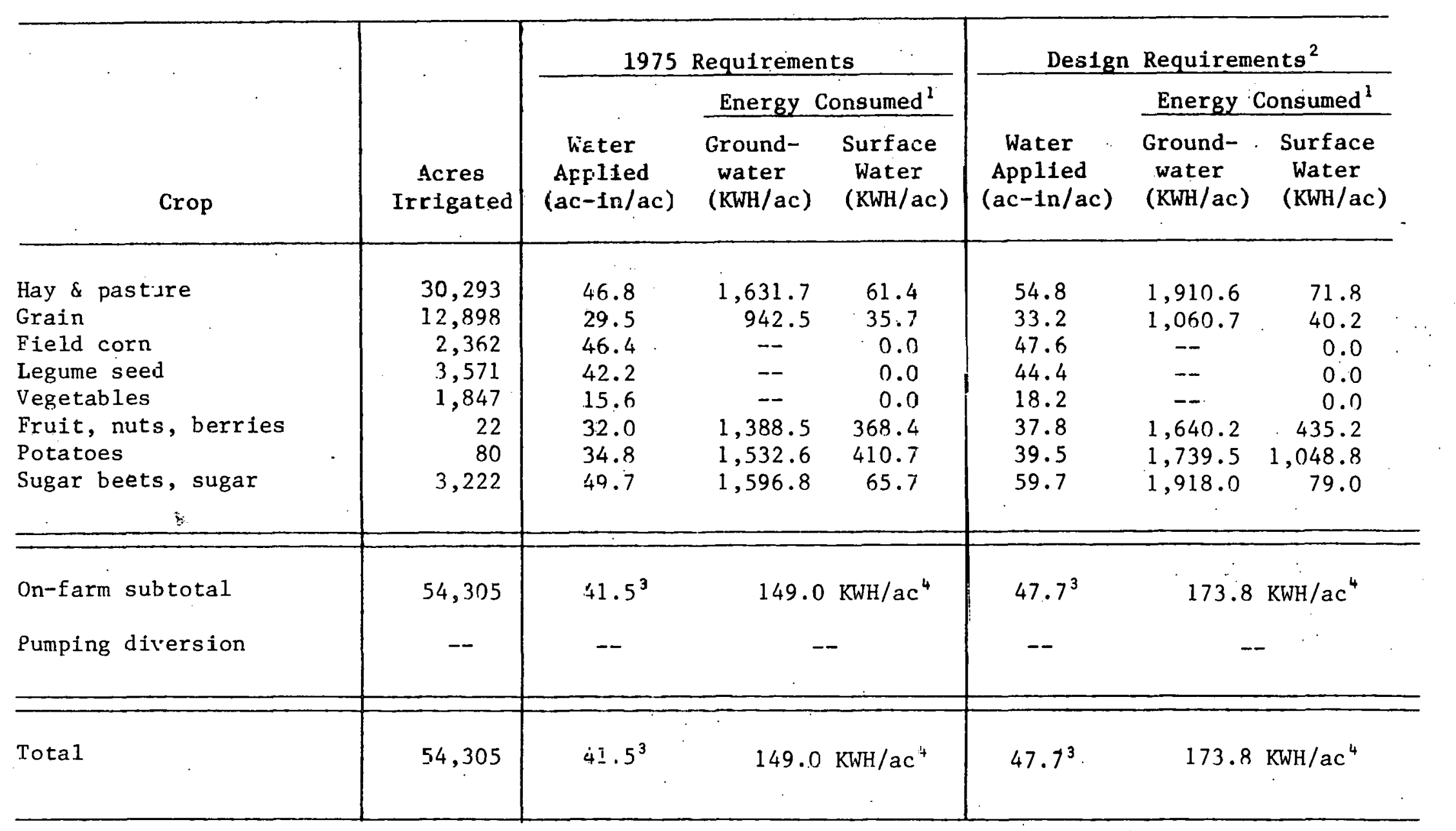

${ }^{1} 92.7 \%$ of the water was supplied by surface sources with average on-farti pumping lifts of 20 feet and the remaining $7.3 \%$ fron groundwater with average lifts of 180 feet.

${ }^{2}$ Values represent the engineering sizing of water and energy required to provide a crop 8 years out of 10 .

${ }^{3}$ Average water consumed for all crops in subregion.

${ }^{4}$ Average energy requizec for all crops and water sources in subarea. 
Table 20 contains the 1975 irrigated crops plus their water and energy requirements. The subarea irrigated 144,462 acres with hay and pastures accounting for 101,699 acres. In addition, the irrigated acreage included small grains, field corn, grass seed, potatoes, mint, dried beans and peas, fruits, nuts and berries.

In 1975 this subarea had 325,039 acre-feet of water applied and consumed 46,999 MWH of electricity. Engineering design requirements were 386,435 acre-feet of water and 55,906 MWH of electricity. Most ( 86.1 percent) of the irrigation water was supplied from surface sources with average on-farm lifts of only 6 feet; the remaining water ( 13.9 percent) was obtained from groundwater sources with average pumping lifts of 90 feet. Two Bureau of Reclamation projects diverted 52,500 acre-feet of water with average lifts of 101 feet to the subarea. In addition, the subarea contained several farmer-operated irrigation districts. In parts of the basin, an overabundance of water necessitated drainage to lower the water table. Gravity irrigation was the major system type with 86,109 acres; side roll, hand move and center pivot irrigated $32,854,22,524$, and 2,222 acres, respectively.

\section{Malheur subarea}

The Malheur Subarea is located in parts of Grant, Harney and Malheur Counties, Oregon. The area is a high, rolling upland region with developed, irrigated bottom lands. It contains four reservoirs which significantly regulate streamflows in the region. 
Table 20. 1975 wat $\supseteq$ r requirenents and energy consumption for irrigation iz Burnt Powder Subarea.

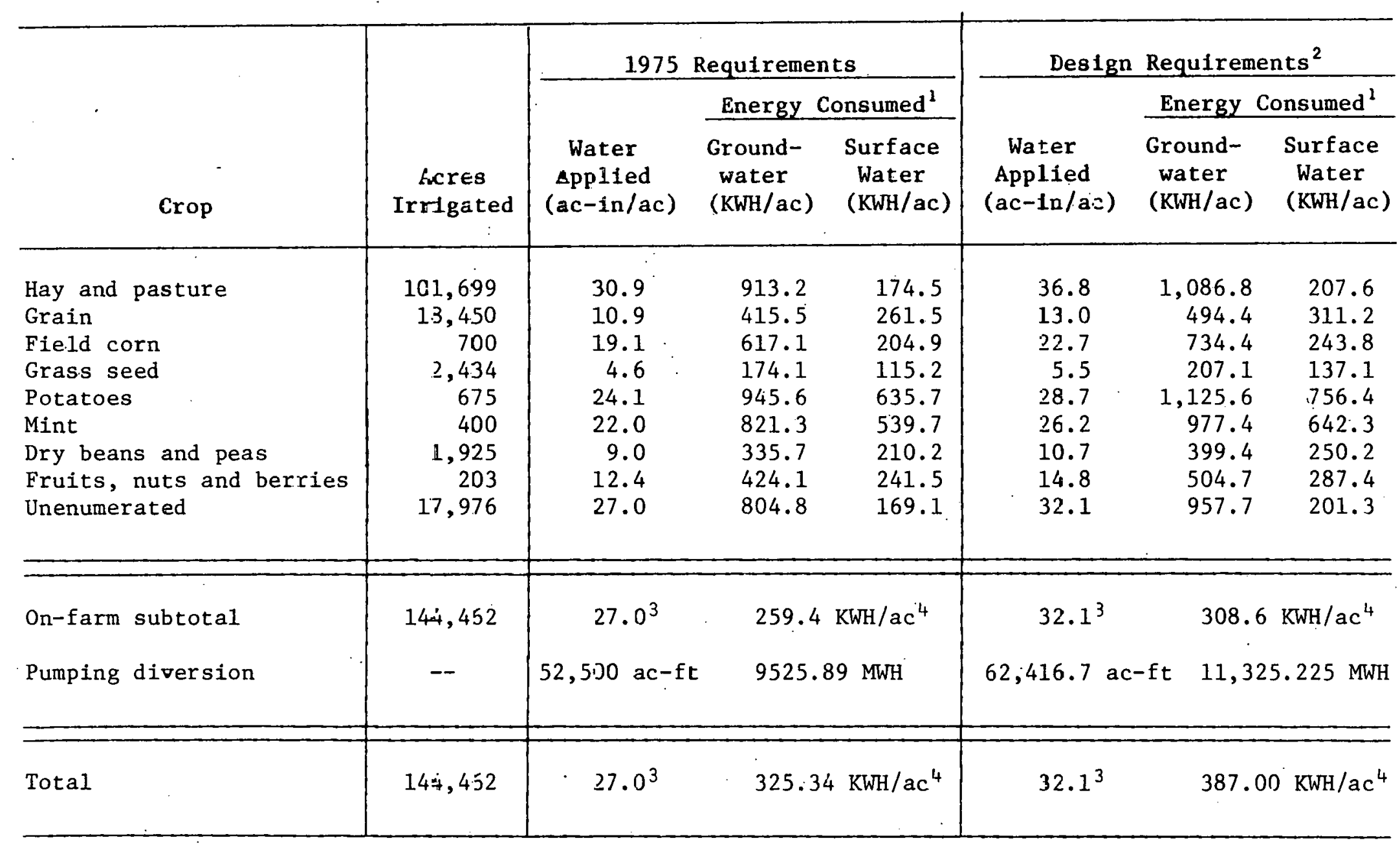

$186.1 \%$ of the water was suppliæd by surface sources with average on-farm pumping 1ifts of 6 feet and the remaining $13.9 \%$ from grouldwater with average lifts of 90 feet.

${ }^{2}$ Values represent the engineering sizing oz water and energy required to provide a crop 8 years out of 10.

${ }^{3}$ Average water consuned for all crops in subregion.

${ }^{4}$ Average energy required for all crops and water sources in subarea. 
Irrigated crops with their water and energy requirements are listed in Table 21. The subarea irrigated 175,494 acres in 1975. Major irrigated crops and their corresponding acreages were: hay and pasture, 107,682 acres; small grains, 27,664 acres; sugar beets, 10,088 acres; field corn, 8,083 acres; vegetables, 6,411 acres; potatoes, 6,200 acres; legume seed, 4,922 acres; and mint, hops and dill, 2,078 acres.

The subarea had 621,541 acre-feet of water applied and used 25,121 MWH of electricity for irrigation in 1975. Engineering design requirements for the corresponding period were 720,988 acre-feet of water and 29,141 MWH of electricity. Surface sources with average on-farm pumping lifts of 25 feet supplied 96.8 percent of the irrigation water. The remaining 3.2 percent was obtained from groundwater sources with average pumping lifts of 63 feet. Diversion pumping supplied 45,541 acre-feet of water to surface sources. Major types of irrigation systems were gravity $(158,752$ acres), hand move and side roll (15,456 acres), and center pivot $(1,085$ acres $)$. 
Table 21. 1975 water requirements and exergy consumption for irrigation in Malheur Subarea.

\begin{tabular}{|c|c|c|c|c|c|c|c|}
\hline \multirow[b]{3}{*}{ Crop } & \multirow[b]{3}{*}{$\begin{array}{c}\text { Acres } \\
\text { Iricigated }\end{array}$} & \multicolumn{3}{|c|}{1975 Requirements } & \multicolumn{3}{|c|}{ Design Requirements ${ }^{2}$} \\
\hline & & \multirow[b]{2}{*}{$\begin{array}{c}\text { Kater } \\
\text { Afplied } \\
(\mathrm{ac}-\ln / \mathrm{ac})\end{array}$} & \multicolumn{2}{|c|}{ Energy Consumed ${ }^{1}$} & \multirow[b]{2}{*}{$\begin{array}{c}\text { Water } \\
\text { Applied } \\
(\mathrm{ac}-\mathrm{in} / \mathrm{ac})\end{array}$} & \multicolumn{2}{|c|}{ Energy Consumed ${ }^{1}$} \\
\hline & & & $\begin{array}{l}\text { Ground- } \\
\text { water } \\
(\mathrm{KWH} / \mathrm{ac})\end{array}$ & $\begin{array}{l}\text { Surface } \\
\text { Water } \\
\text { (KWH/ac) }\end{array}$ & & $\begin{array}{c}\text { Ground- } \\
\text { water } \\
(\mathrm{KWH} / \mathrm{ac})\end{array}$ & $\begin{array}{l}\text { Surface } \\
\text { Water } \\
\text { (KWH/ac) }\end{array}$ \\
\hline $\begin{array}{l}\text { Hay and pasture } \\
\text { Grain } \\
\text { Field corn } \\
\text { Legume seed } \\
\text { Potatoes } \\
\text { Mint, hops and dills } \\
\text { Sugar beets, sugar } \\
\text { Vegetables } \\
\text { Unenumerated }\end{array}$ & $\begin{array}{r}107,582 \\
27,564 \\
8,583 \\
4,, 922 \\
6,200 \\
2,078 \\
-0,088 \\
6,411 \\
2,366\end{array}$ & $\begin{array}{l}47.8 \\
30.0 \\
33.1 \\
37.0 \\
36.5 \\
32.4 \\
42.4 \\
32.1 \\
41.5\end{array}$ & $\begin{array}{r}1,150.7 \\
719.1 \\
790.6 \\
883.6 \\
884.0 \\
817.2 \\
1,017.6 \\
767.4 \\
666.7\end{array}$ & $\begin{array}{l}92.1 \\
55.1 \\
57.5 \\
64.3 \\
78.7 \\
59.1 \\
84.8 \\
55.8 \\
83.0\end{array}$ & $\begin{array}{l}55.4 \\
34.8 \\
38.5 \\
42.9 \\
42.3 \\
39.7 \\
49.2 \\
37.2 \\
48.2\end{array}$ & $\begin{array}{r}1,334.8 \\
834.2 \\
917.1 \\
1,025.0 \\
1,025.4 \\
947.9 \\
1,180.4 \\
890.1 \\
773.3\end{array}$ & $\begin{array}{r}106.8 \\
63.9 \\
66.7 \\
74.6 \\
91.3 \\
68.6 \\
98.4 \\
64.8 \\
96.2\end{array}$ \\
\hline On-farm subtotal & 175,494 & $42.5^{3}$ & 110.6 & $\mathrm{KWH} / \mathrm{ac}^{4}$ & $49.3^{3}$ & 128.3 & $\mathrm{KWH} / \mathrm{ac}^{4}$ \\
\hline Pumping diversion & -- & $45,541 \mathrm{ac}-\mathrm{ft}$ & 5,711 & $138 \mathrm{MWH}$ & $52,827.56$ & $c-f t \quad 6,624$ & $.920 \mathrm{MWH}$ \\
\hline Tota 1 & $175, \dot{494}$ & $42.5^{3}$ & 143.1 & $4 \mathrm{KWH} / \mathrm{ac}^{4}$ & $49.3^{3}$ & 166.0 & 5. KWH/ $/ \mathrm{ac}^{4}$ \\
\hline
\end{tabular}

$196.8 \%$ of the water was supplied by surface sources with average on-farm pumpirg lifts of 25 feet and the remaining $3.2 \%$ from groutdwater with average lifts of 63 feet.

${ }^{2}$ Values represent t:-e engineering sizing of water and energy required to provide a crop 8 years out of 10 .

${ }^{3}$ Average water consumel for all crops in subregion.

${ }^{4}$ Average energy required for all crops and water sources in subarea. 


\section{SUBREGION 6}

Lower Snake

This subregion consists of the lower third of the snake River Basin and includes contiguous land in three states -oregon, Washington and Idaho. Of the 22.5 million acres in the subregion, 70 percent are in Idaho, 16 percent in Washington and the remaining 14 percent in Oregon.

This region includes the drainage areas of the Snake River and its tributaries from above Hells Canyon Dam downstream to the confluence of the Snake and Columbia Rivers. Major tributaries of this reach of the snake River are the Clearwater and Salmon Rivers in Idaho, the Palouse and Tucannon Rivers in Washington and the Grande Ronde and Imnaha Rivers in Oregon.

The subregion varies in elevation from 340 feet to more than 12,000 feet above sea level. The area is rather rugged, with the northern section containing the Walla walla Plateau, the western portion in the columbia Plateau, the southern section in the Blue Mountain province, and the eastern portion in the Northern Rocky Mountain province. The Lower Snake has been partitioned into the following five subareas shown in Figure 7: Palouse Lower Snake, Grande Ronde, Clearwater, Salmon and Upper Salmon.

A total of 267,270 acres was irrigated in this subregion in 1975. Almost half of the total irrigated acreage $(120,540$ acres) was in the Upper Salmon subarea. In addition; Palouse Lower Snake and Grande Ronde subareas irrigated 44,675 and 83,465 acres, respectively, in 1975 . 
Over half of the subregion was irrigated with gravity systems (151,493 acres). Remaining systems and their corresponding acreages were: 66,827 acres of side roll; 27,758 acres of hand move; 15,657 acres of center pivot; 2,000 acres of permanent; 1,297 acres of big gun; 2,215 acres of solid set; and 23 acres of drip.

Hay and pastures were the major irrigated crops; 192,932 acres, representing 72 percent of the subregion, were irrigated. Additional irrigated crops were field corn, vegetables, potatoes, grass seed, sugar beets, dried beans and peas, fruite, nute and berries.

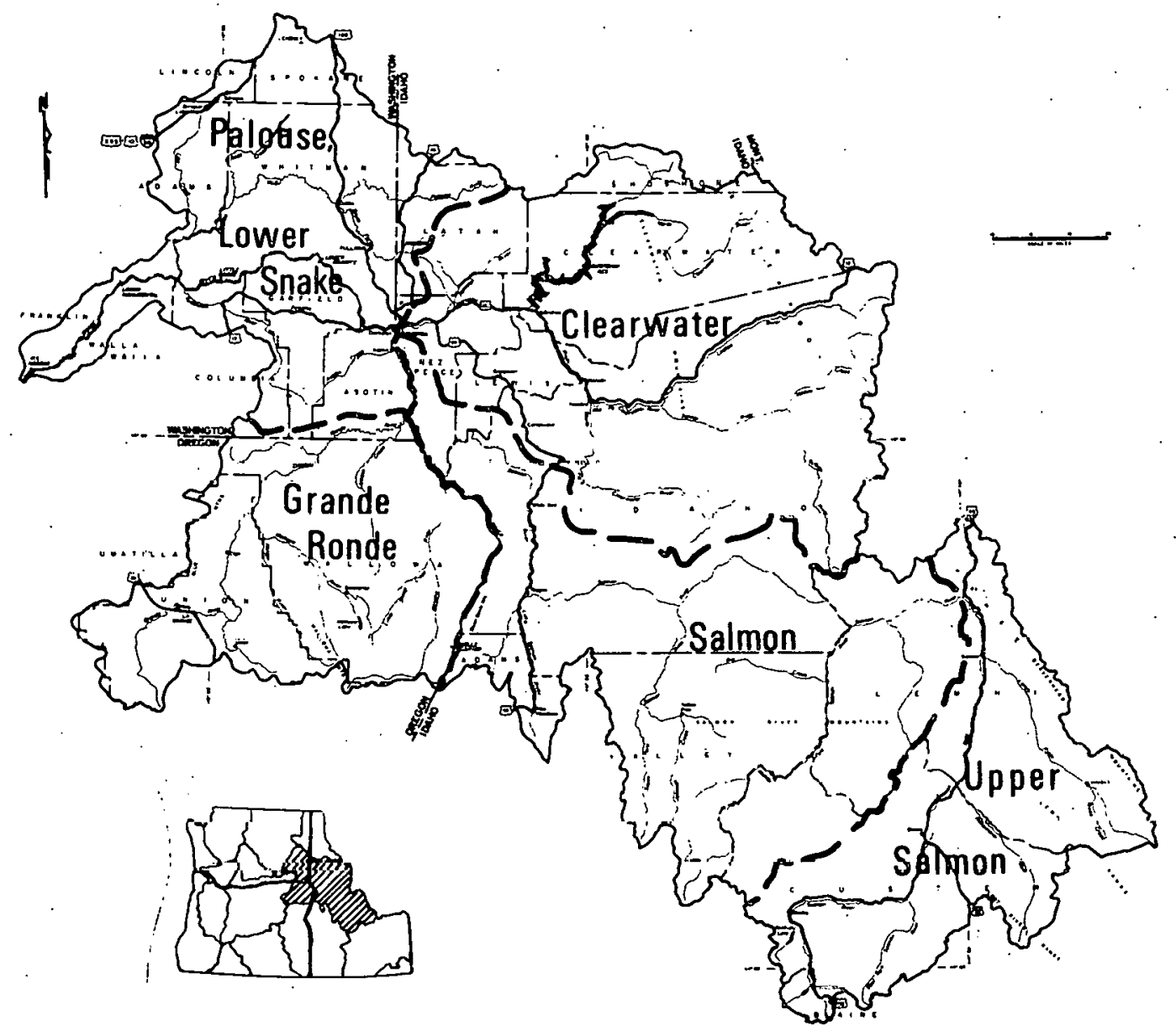

Figure 7. Map of Subregion 6 containing Palouse Lower Snake, Grande Ronde, Clearwater, Salmon, and Upper Salmon. Subareas. 
Approximately 674,998 acre-feet of water were applied and 125,666 MWH of electricity were used in this subregion for irrigation. Engineering design requirements for this same period were 765,779 acre-feet of water and $140,378 \mathrm{MWH}$ of electricity.

\section{Clearwater subarea}

Clearwater subarea is located in the northeastern section of the subregion, which also is in central Idaho. The area is mainly contained in clearwater, Lewis and Idaho Counties, Idaho. The drainage basin includes the Clearwater River and its tributaries-North, South and Middle Forks of Clearwater, Locksa and Selway Rivers. The rugged Clearwater Mountains and the Selway-Bitterroot wilderness are in the basin.

Table 22 contains the 1975 energy and water requirements for irrigation in Clearwater subarea. Total irrigation in this subarea was only 1,892 acres, all of which was applied solely by hand move systems. Irrigated crops and their acreages were: 1,387 acres of hay and pastures; 145 acres of field corn, 307 acres of vegetables; 22 acres of fruits, nuts and berries; and 31 acres of potatoes.

The 1,892 irrigated acres had 4,162 acre-feet of water applied and used 1,449 MWH of electricity. Engineering design requirements were 5,093 acre-feet of water and 1,771 MWH of electricity. The area does not contain diversion pumping plants. 
Table 22. 1975 water requirements and energy corsumption for irrigation in the Clearwater Subarea.

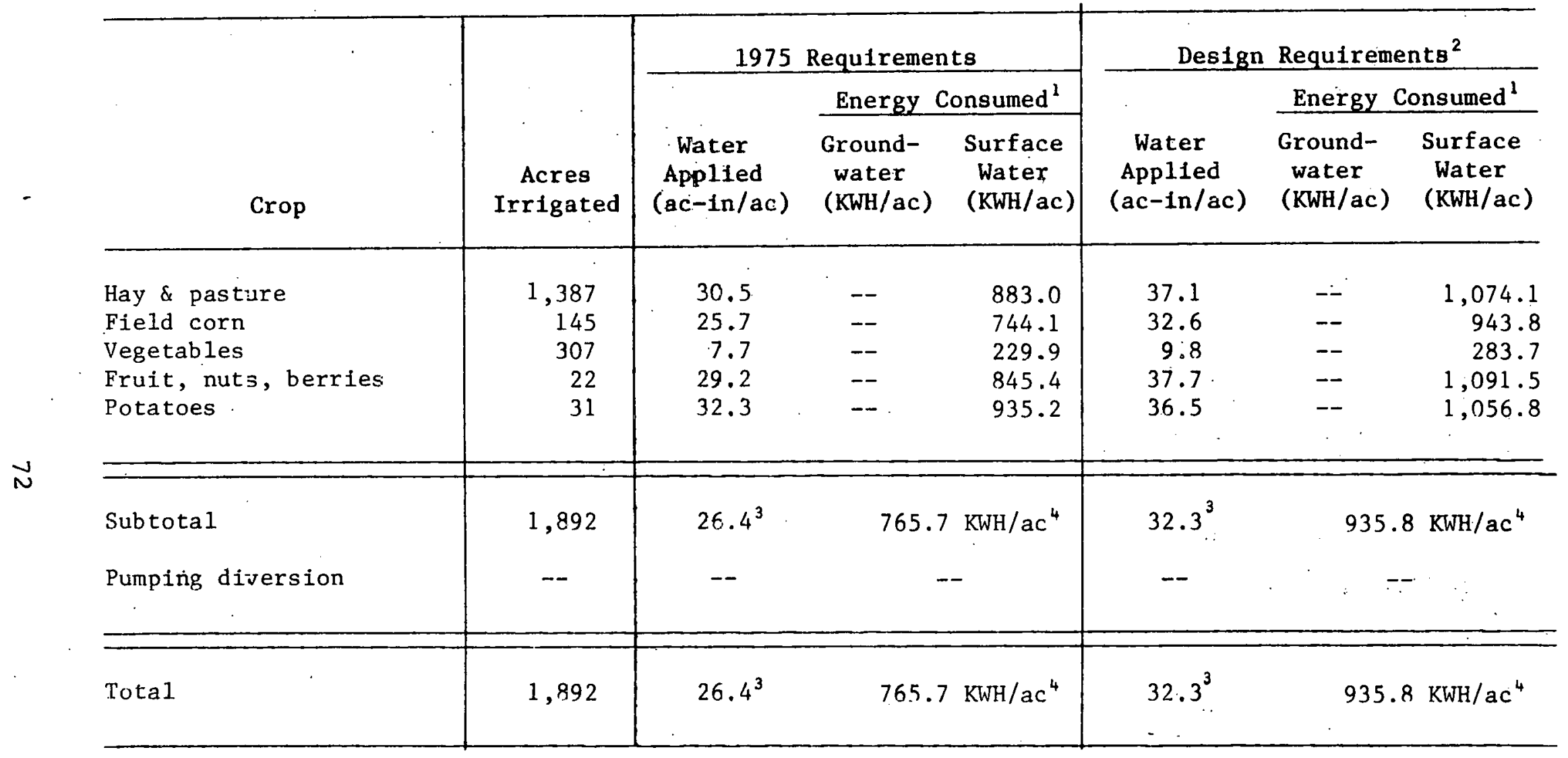

$1100 \%$ of the water was supflied by surface sources with average on-farn pumping lifts of $35 \mathrm{feet}$.

${ }^{2} \mathrm{Values}$ represent the engireering sizing of water and energy required ro provide a crop 8 years out of 10 .

${ }^{3}$ Average water consumed for all crops in subregion.

${ }^{4}$ Average energy required for all crops and water sources in subarea. 


\section{Palouse-Lower snake Subarea}

Located in the southeastern corner of Washington, this subarea contains parts of Lincoln, Spokane, Adams, Whitman, Franklin, Walla Walla, Columbia, Garfield and Asotin Counties, Washington; part of Latah county, Idaho is also included. The subarea includes the lower section of the snake River from its mouth to Lewiston. Palouse Lower Snake is a highly productive dryland wheat region.

Table 23 lists the 1975 energy and water requirements for irrigation in this area. A total of 44,675 acres was irrigated in 1975. The major irrigated crops were: small grains with 15,856 acres; 13,049 acres of hay and pasture; and 7,967 acres of potatoes. Grass seed, vegetables, fruits, nuts, berries, and sugar beets were also irrigated.

Approximately 116,530 acre-feet of water were applied and $81,041 \mathrm{MWH}$ of electricity were consumed on the 44,675 acres in 1975. Engineexing design requirements were 122,112 acre-feet and $85,092 \mathrm{MWH}$ of electricity. In addition, 92,648 acre-feet of water were delivered to surface sources by lifting water 200 feet.

Side roll and center pivot were the predominant irrigation systems with 20,687 and 15,000 acres, respectively, in 1975 . Additional systems and their acreages were: hand move with 4,850 acres; permanent with 2,000 acres; solid set with 1,038 acres; big gun with 1,000 acres; and gravity with 100 acres. 
Table 23. 1975 water requirements and energy consumption for irrigation in the Palouse Lower Snake Sisbarea.

\begin{tabular}{|c|c|c|c|c|c|c|c|}
\hline \multirow[b]{3}{*}{ Crop } & \multirow[b]{3}{*}{$\begin{array}{c}\text { Acres } \\
\text { Irrigated }\end{array}$} & \multicolumn{3}{|c|}{1975 Requirements } & \multicolumn{3}{|c|}{ Des1gn Requirements? } \\
\hline & & \multirow[b]{2}{*}{$\begin{array}{c}\text { Water } \\
\text { Applied } \\
(a c-1 n / a c)\end{array}$} & \multicolumn{2}{|c|}{ Energy Consumed ${ }^{1}$} & \multirow[b]{2}{*}{$\begin{array}{c}\text { Water } \\
\text { Applled } \\
(\mathrm{ac}-1 \mathrm{n} / \mathrm{ac})\end{array}$} & \multicolumn{2}{|c|}{ Energy Consumed ${ }^{2}$} \\
\hline & & & $\begin{array}{l}\text { Ground- } \\
\text { water } \\
(\mathrm{KWH} / \mathrm{ac})\end{array}$ & $\begin{array}{l}\text { Surface } \\
\text { Water } \\
\text { (KWH/ac) }\end{array}$ & & $\begin{array}{l}\text { Ground- } \\
\text { water } \\
(\mathrm{KWH} / \mathrm{ac})\end{array}$ & $\begin{array}{c}\text { Surface } \\
\text { Water } \\
(\mathrm{KWH} / \mathrm{ac})\end{array}$ \\
\hline $\begin{array}{l}\text { Hay and pasture } \\
\text { Grain } \\
\text { Potatoes } \\
\text { Grass and legume seed } \\
\text { Vegetables } \\
\text { Fruits, nuts \& berries } \\
\text { Sugar beet sugar }\end{array}$ & $\begin{array}{r}13,049 \\
15,856 \\
7,967 \\
572 \\
2,681 \\
1,800 \\
2,750\end{array}$ & $\begin{array}{l}43.2 \\
19.0 \\
28.6 \\
41.0 \\
32.6 \\
51.2 \\
36.9\end{array}$ & $\begin{array}{l}2,453.3 \\
1,083.2 \\
1,728.4 \\
2,249.1 \\
1,749.5 \\
2,802.2 \\
2,200.9\end{array}$ & $\begin{array}{r}1,364.0 \\
601.0 \\
1,004.7 \\
1,218.3 \\
951.3 \\
1,514.9 \\
1,222.8\end{array}$ & $\begin{array}{l}45.3 \\
19.9 \\
30.0 \\
43.1 \\
34.2 \\
53.8 \\
38.8\end{array}$ & $\begin{array}{l}2,576.0 \\
1,137.4 \\
1,814.8 \\
2,361.6 \\
1,837.0 \\
2,942: 3 \\
2,311.0\end{array}$ & $\begin{array}{r}1,432.2 \\
631.2 \\
1,055.0 \\
1,279.2 \\
998.8 \\
1,590.6 \\
1,284 . ?\end{array}$ \\
\hline On-farm stbtotal & 44,675 & $31.3^{3}$ & 1,160 . & $6 \mathrm{KWH} / \mathrm{ac}^{4}$ & $32 . \varepsilon^{3}$ & $1,218.6$ & $6 \mathrm{KWH} / \mathrm{ac}{ }^{4}$ \\
\hline Pumping diversion & -- & $92.648 \mathrm{ac}-\mathrm{ft}$ & 29,191 & $249 \mathrm{MWH}$ & $97,280 \mathrm{ac}-\mathrm{ft}$ & 30,650 & $0.812 \mathrm{MWH}$ \\
\hline Total & 44,675 & $31.3^{3}$ & 1,814 . & $0 \mathrm{KWH} / \mathrm{ac}^{4}$ & $32.8^{3}$ & 1,904 . & $68 \mathrm{KWH} / \mathrm{ac}^{4}$ \\
\hline
\end{tabular}

$180 \%$ of the water was supplied by surface sources with average on-farn pumping lifts of 35 feet and the remaining $20 \%$ from groundwater with average lifts of 200 feet.

${ }^{2}$ Values represent the engineering sizing cf water and energy required to provide a crop 8 years out of 10 .

${ }^{3}$ Average water consumed for all crops in subregion.

${ }^{4}$ Average energy required for all crops and water sources in subarea. 


\section{Grande Ronde Subarea}

Grande Ronde Subarea is located in the northeastern corner of Oregon and southeastern Washington. It contains Wallowa and part of Union Counties, Oregon, and parts of Asotin, Garfield, and Columbia Counties, Washington. The area includes high mountainous regions, rolling sage-covered hills and fertile valleys. In the northeastern portion is a range area where rivers have deeply cut into rock formations along the Grande Ronde River. Agriculture and timber production are the area's primary industries.

Energy and water requirements in 1975 for irrigation in this area are listed in Table 24. A total of 83,465 acres was irrigated in 1975 with hay and pasture accounting for 46,982 acres. Small grain grass seed, potatoes, dried beans and peas, fruits, nuts and berries were also irrigated.

The 83,465 acres had 171,799 acre-feet of water applied and used 32,885 MWH of electricity. Corresponding engineering design requirements were 223,269 acre-feet of water and 42,650 MWH of electricity. Surface sources, with average on-farm lifts of 20 feet, supplied 93.1 percent of the water. The remaining 6.9 percent was obtained from groundwater with average lifts of 26 feet.

Side roll systems irrigated over 55 percent of the subarea, with 46,702 acres. Other major systems were gravity with 25,168 acres and hand move with 10,403 acres. 
Table 24. 1975 water reqsirements and energy consumption for irrigation in the Grande Ronde Subarea.

\begin{tabular}{|c|c|c|c|c|c|c|c|}
\hline \multirow[b]{3}{*}{ Crop } & \multirow[b]{3}{*}{$\begin{array}{c}\text { Acres } \\
\text { Irrigated }\end{array}$} & \multicolumn{3}{|c|}{1975 Requirements } & \multicolumn{3}{|c|}{ Des1gn Requirements ${ }^{2}$} \\
\hline & & \multirow[b]{2}{*}{$\begin{array}{c}\text { Water } \\
\text { App11ed } \\
(\mathrm{ac}-1 \mathrm{n} / \mathrm{ac})\end{array}$} & \multicolumn{2}{|c|}{ Energy Consumed ${ }^{1}$} & \multirow[b]{2}{*}{$\begin{array}{c}\text { Water } \\
\text { Applied } \\
(\mathrm{ac}-\mathrm{in} / \mathrm{ac})\end{array}$} & \multicolumn{2}{|c|}{ Energy Consumed ${ }^{l}$} \\
\hline & & & $\begin{array}{l}\text { Ground- } \\
\text { water } \\
(\mathrm{KWH} / \mathrm{ac})\end{array}$ & $\begin{array}{c}\text { Surface } \\
\text { Water } \\
(\mathrm{KWH} / \mathrm{ac})\end{array}$ & & $\begin{array}{l}\text { Ground- } \\
\text { water } \\
\text { (KWH/ac) }\end{array}$ & $\begin{array}{l}\text { Surface } \\
\text { Water } \\
\text { (KWH/ac) }\end{array}$ \\
\hline $\begin{array}{l}\text { Hay and pasture } \\
\text { Grain } \\
\text { Grass seed } \\
\text { Potatoes } \\
\text { Dry beans and peas } \\
\text { Fruit, nuts } \& \text { berries }\end{array}$ & $\begin{array}{r}46,982 \\
29,040 \\
3,566 \\
905 \\
2,675 \\
297\end{array}$ & $\begin{array}{r}32.1 \\
16.6 \\
3.1 \\
30.7 \\
9.0 \\
25.6\end{array}$ & $\begin{array}{r}768.4 \\
463.1 \\
87.7 \\
887.1 \\
251.7 \\
653.5\end{array}$ & $\begin{array}{r}379.3 \\
415.6 \\
84.2 \\
859.0 \\
243.4 \\
--\end{array}$ & $\begin{array}{r}41 . ? \\
21.6 \\
4.0 \\
39.9 \\
11.7 \\
33.2\end{array}$ & $\begin{array}{r}998.9 \\
602.0 \\
114.0 \\
1,153.2 \\
327.2 \\
849.5\end{array}$ & $\begin{array}{r}493.0 \\
540.3 \\
109.5 \\
1,116.8 \\
316.5 \\
--\end{array}$ \\
\hline $\begin{array}{l}\text { On-farm subtotal } \\
\text { Pumping d-version }\end{array}$ & $\begin{array}{c}83,465 \\
--\end{array}$ & $\begin{array}{c}24.7^{3} \\
--\end{array}$ & 394.0 & $\mathrm{KWH} / \mathrm{ac}^{4}$ & $\begin{array}{c}32.1^{3} \\
--\end{array}$ & 511.0 & $\mathrm{KWH} / \mathrm{ac}^{4}$ \\
\hline Total & 83,465 & $24.7^{3}$ & 394.0 & $\mathrm{KWH} / \mathrm{ac}^{4}$ & $32.1^{3}$ & 511.0 & $\mathrm{KWH} / \mathrm{ac}^{4}$ \\
\hline
\end{tabular}

$193.1 \%$ of the water was supplied by surface sourses with average on-farm purping 1 ifts of 20 feet and the remaining $6.5 \%$ from groundwater with average lifts of 26 feet.

${ }^{2}$ Values represent the engineering sizing of water and energy required to prcvide a crop 8 years out of 10.

${ }^{3}$ Average water consumed for all crops in subregion.

${ }^{4}$ Average energy required for all crops and water sources in subarea. 


\section{Salmon Subarea}

The Salmon Subarea is located in western Idaho and contains part of Valley, Idaho, Lewis, Nez Perce, Adams, Custer and Lemhi Counties. The area includes the Salmon River drainage basin below the North Fork and Idaho tributaries of the Snake River from Hells canyon to the mouth of the Salmon. The Salmon River Mountains are also included in this subarea and contain some of the region's most rugged landscape.

Table 25 contains the 1975 irrigation water and energy requirements for the Salmon subarea. The area contained 16,698 irrigated acres with hay and pasture consuming 99 percent of the acreage. Remaining irrigated crops were field corn, vegetables, potatoes, fruit and nuts.

A total of 57,051 acre-feet of water was applied and 4,418 MWH of electricity was used to irrigate the 16,698 acres. Engineering design requirements for the corresponding period were 63,731 acre-feet of water and 4,934 MWH of electricity. Surface water, with average on-farm lifts of 53 feet, supplied 99 percent of the irrigation water; the remaining one percent was obtained from groundwater with 50 feet lifts. The subarea did not contain large diversion pumping stations.

Again, the majority (76 percent) of the irrigation was by gravity systems; the remaining acreage (4.013 acres) was irrigatcd with hand move systems. 
Table 25. 1975 water requirements and energy consumption for irrigation ir. Salmon Subarea.

\begin{tabular}{|c|c|c|c|c|c|c|c|}
\hline \multirow[b]{3}{*}{ Crop } & \multirow[b]{3}{*}{$\begin{array}{l}\text { Acrés } \\
\text { Irrigated }\end{array}$} & \multicolumn{3}{|c|}{1975 Requirements } & \multicolumn{3}{|c|}{ Design Requirements ${ }^{2}$} \\
\hline & & \multirow[b]{2}{*}{$\begin{array}{c}\text { Water } \\
\text { Applied } \\
(a c-1 n / a c)\end{array}$} & \multicolumn{2}{|c|}{ Energy Consumed ${ }^{1}$} & \multirow[b]{2}{*}{$\begin{array}{c}\text { Water } \\
\text { Applied } \\
(\text { ac-1n/ac) }\end{array}$} & \multicolumn{2}{|c|}{ Energy Consumed" } \\
\hline & & & $\begin{array}{l}\text { Ground- } \\
\text { water } \\
\text { (KWH/ac) }\end{array}$ & $\begin{array}{l}\text { Surface } \\
\text { Wạter } \\
\text { (KWH/ac) }\end{array}$ & & $\begin{array}{l}\text { Ground- } \\
\text { water } \\
\text { (KWH/ac) }\end{array}$ & $\begin{array}{l}\text { Surface } \\
\text { Water } \\
\text { (KWH/ac) }\end{array}$ \\
\hline $\begin{array}{l}\text { Hay and pasture } \\
\text { Vegetables } \\
\text { Corn } \\
\text { Fruits, nuts \& berries } \\
\text { Potatoes }\end{array}$ & $\begin{array}{r}-6,485 \\
53 \\
95 \\
63 \\
2\end{array}$ & $\begin{array}{l}41.1 \\
21.8 \\
36.9 \\
29.4 \\
44.4\end{array}$ & $\begin{array}{c}1,055.8 \\
-- \\
-- \\
762.2 \\
--\end{array}$ & $\begin{array}{r}256.7 \\
0.0 \\
0.0 \\
931.8 \\
0.0\end{array}$ & $\begin{array}{l}45.9 \\
24.4 \\
48.0 \\
32.9 \\
54.9\end{array}$ & $\begin{array}{c}1,17.9 .2 \\
-- \\
-- \\
853.0 \\
--\end{array}$ & $\begin{array}{r}286.7 \\
0.0 \\
0.0 \\
1,0.42 .8 \\
0.0\end{array}$ \\
\hline On-farm stbtotal & 16,698 & $41.0^{3}$ & 264.6 & $\mathrm{KWH} / \mathrm{ac}^{4}$ & $45.8^{3}$ & 295.5 & $\mathrm{KWH} / \mathrm{ac}^{4}$ \\
\hline Pumping diversion & -- & -- & & -- & -- & $\therefore$ & $-二$ \\
\hline Total & 16,698 & $41.0^{3}$ & 264.6 & $\mathrm{KWH} / \mathrm{ac}^{4}$ & $45 . \varepsilon^{3}$ & 295.5 & $\mathrm{KWH} / \mathrm{ac}{ }^{4}$ \\
\hline
\end{tabular}

$199 \%$ of the water was suppied by surface sources with average on-farm pumping lifts of 53 . feet and the remaining $1 \%$ from groundwater with average lifts of 50 feet.

2.Values represent the enginee out of 10 .

${ }^{3}$ Average water consumed for a-1 crops in subregion.

${ }^{4}$ Average energy required for all crops and water sources in subarea. 


\section{Upper Salmon Subarea}

Upper Salmon subarea is located in the southeastern corner of the subregion. The subarea includes the salmon. River down to and including the North Fork and the Lemhi and Pahsimeroi Rivers. Except for cattle ranches and a few small towns, this basin is largely uninhabited. The salmon River and its tributaries support a major portion of the last remaining salmon and steelhead in Idaho:

The 1975 irrigation water application and energy consumption are reported in Table 26. Over 120,500 acres were irrigated in 1975. Ninety-five percent of the total irrigated acreage produced hay and pasture (115,029 acres). In addition, 5,343 acres of small grains were irrigated plus limited acreages of potatoes, vegetables, fruit and nuts. The subarea applied 325,458 acre-feet of water and used 5,472.5 MWH of electricity in 1975. Engineering design requirements. for 1975 were 351,575 acre-feet of water and 5,930.5 MWH of electricity. Surface sources supplied 99.3 percent of the irrigation water in this subarea; average on-farm lifts were 25 feet. The remaining 0.7 percent of the water was supplied from groundwater with average lifts of 100 feet.

Gravity irrigation systems predominated, with 113,540 acres. In addition, hand move and side roll systems irrigated 6,600 and 400 acres, respectively. 
Table 26. 1975 water requirenents and energy consumption for irrigation in the Upper Salmon Subarea.

\begin{tabular}{|c|c|c|c|c|c|c|c|}
\hline \multirow[b]{3}{*}{ Crop } & \multirow[b]{3}{*}{$\begin{array}{c}\text { Acres } \\
\text { Irrigated }\end{array}$} & \multicolumn{3}{|c|}{1975 Requirements } & \multicolumn{3}{|c|}{ Design Requirements ${ }^{2}$} \\
\hline & & \multirow[b]{2}{*}{$\begin{array}{l}\text { Water } \\
\text { Applied } \\
(a c-i n / a c)\end{array}$} & \multicolumn{2}{|c|}{ Energy Consumed ${ }^{1}$} & \multirow[b]{2}{*}{$\begin{array}{c}\text { Water } \\
\text { Applied } \\
(\mathrm{ac}-\mathrm{in} / \mathrm{ac})\end{array}$} & \multicolumn{2}{|c|}{ Energy Consumed } \\
\hline & & & $\begin{array}{c}\text { Ground- } \\
\text { water } \\
(\mathrm{KWH} / \mathrm{ac})\end{array}$ & $\begin{array}{l}\text { Surface } \\
\text { Water } \\
\text { (KWH/ac) }\end{array}$ & & $\begin{array}{l}\text { Ground- } \\
\text { water } \\
\text { (KWHi/ac) }\end{array}$ & $\begin{array}{c}\text { Surface } \\
\text { Water } \\
\text { (KWH/ac) }\end{array}$ \\
\hline $\begin{array}{l}\text { Hay and pasture } \\
\text { Grain } \\
\text { Potatoes } \\
\text { Vegetabl€s } \\
\text { Fruits, nuts \& berries }\end{array}$ & $\begin{array}{r}115,029 \\
5,343 \\
160 \\
5 \\
3\end{array}$ & $\begin{array}{l}32.7 \\
26.5 \\
26.3 \\
13.1 \\
38.4\end{array}$ & $\begin{array}{r}991.7 \\
800.5 \\
1,042.0 \\
-- \\
--\end{array}$ & $\begin{array}{r}32.5 \\
158.6 \\
741.4 \\
0.0 \\
0.0\end{array}$ & $\begin{array}{l}35.3 \\
29.2 \\
28.2 \\
14.2 \\
41.6\end{array}$ & $\begin{array}{r}1,070.6 \\
882.0 \\
1,117.3 \\
-- \\
--\end{array}$ & $\begin{array}{r}35.1 \\
174.8 \\
79.5 \\
0.0 \\
0.0\end{array}$ \\
\hline $\begin{array}{l}\text { On-farm subtotal } \\
\text { Pumping civersion }\end{array}$ & $\begin{array}{c}120.540 \\
--\end{array}$ & $\begin{array}{l}32.4^{3} \\
--\end{array}$ & 45.4 & $\mathrm{KWH} / \mathrm{ac} \mathrm{c}^{4}$ & $35.0^{3}$ & 49.2 & $\mathrm{KWH} / \mathrm{ac} 4$ \\
\hline Total & $=20,540$ & $32.4^{3}$ & 45.4 & $\mathrm{KWH} / \mathrm{ac}^{4}$ & $35.0^{3}$ & 49.2 & $\mathrm{KNH} / \mathrm{ac}^{4}$ \\
\hline
\end{tabular}

$199.3 \%$ of the water was supplied by surface sources with average on-farm pumping lifts of 25 feet and the remaining $0.7 \%$ from groundwater with average lifts of $100 \mathrm{f}$ eet.

${ }^{2}$ Values represent the engineerizg sizing of water and energy required to provide a crop 8 years out of 10 .

${ }^{3}$ Average water consumed for all crops in subregion.

${ }^{4}$ Average energy required for all crops and water sources in subarea. 


\section{SUBREGION 7}

Mid-Col umbia

This area includes approximately 29,000 square miles of land in Oregon and Washington between the Cascade Range and the Blue Mountains drained by tributaries of the Columbia River. Approximately 82 percent of the area is in Oregon and 18 percent in Washington.

Prominent land formations include the Cascade Range on the west, Horse Heaven Hills on the north, Blue Mountains on the east, and extensive uplands on the south. The major tributaries of the Columbia are John Day, Deschutes, Hood River, Walla Walla, White Salmon, Klickitat and Umatilla.

To facilitate the data presentation, this subregion is divided into six subareas based upon hydrologic boundaries (see Figure 8). The subareas are Northside Columbia, Walla Walla, Umatilla, Hood, John Day, and Deschutes.

Irrigation first appeared in this subregion during the last third of the nineteenth century. Most of the early irrigators used direct diversions from small streams, which involved an individual or small group effort. Irrigated acreages have substantially increased since pre-twentieth century days with several large concentrations of irrigated land which pump directly from rivers via project-type developments.

This subregion contained 575,574-acres of irrigated lands in 1975 with Deschutes, Umatilla, Northside Columbia, Walla Walla, John Day and Hood Subareas irrigating 186,033 acres; 156,803 acres, 79,000 acres, 70,462 acres, 56,491 acres, and 26,785 acres, respectively. The subregion had $1,763,840$ acre-feet of water applied and used $774,270.3 \mathrm{MWH}$ of 


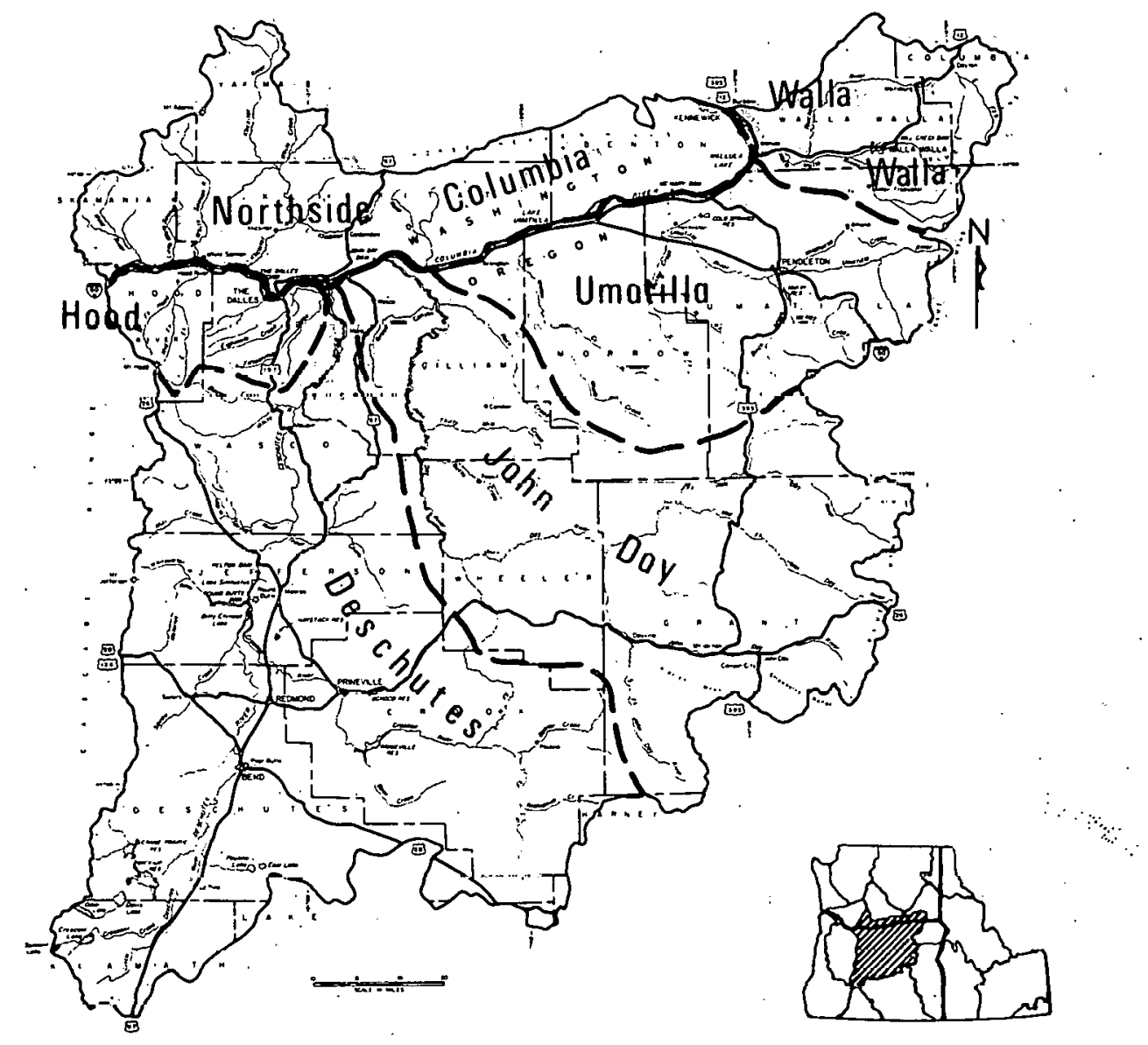

Figure 8. Map of Subregion 7 containing Northside Columbia, Walla Walla, Umatilla, Hood, John Day and Deschutes Subareas.

electricity. Engineering design requirements for 1975 were $1,731,544$ acre-feet of water and $746,434.8 \mathrm{MWH}$ of electricity. Selected crop-soil conditions coupled with management practices resulted in over-irrigation in parts (mainly Northside Columbia, Walla Walla, Deschutes and Umatilla Subareas) of the subregion. These conditions escalated the 
subregion's actual water application and energy consumption above the engineering design requirement, even though other parts of the subregion did not have sufficient irrigation water.

Of the 575,574 acres under. irrigation, 48 percent, 277,264 acres, contained hay and pasture. Additional major crops include small grains, potatoes, vegetables and grass seed. Also, limited acreages of mint, hops, dill, field corn, sugar beets, dry beans and peas, garlic, fruit, nuts and berries were irrigated in 1975. All major types of irrigation systems were used with acreages as follows: 195,003 acres of side roll; 135,639 acres of center pivot; 134,843 acres of gravity; 100,365 acres of hand move; 5,299 acres of solid set; 3,274 acres of permanent; and 246 acres of drip.

\section{Walla Walla Subarea}

Walla Walla Subarea is located in northeastern Oregon and southeastern Washington. The subarea lies in Columbia and Walla Walla Counties, Washington and Umatilla County, oregon. The area consists of the Walla Walla River drainage basin including the Touchet River and Mill Creek. The southern part of the subarea is mountainous. Local economy is based largely on agriculture and produces a variety of irrigated crops.

Table 27 contains the 1975 irrigation water and energy requirements of the Walla Walla Subarea. This subarea had 70,462 acres of irrigated crops with hay, pasture and small grains encompassing almost 52,000 acres. The subarea also irrigated 7,644 acres of vegetables, 6,574 acres of grass and legume seed, and a variety of additional limited acreage crops. 
Table 27. 1975 water requirements and energy consumption for irrigation in Walla Walla Subarea.

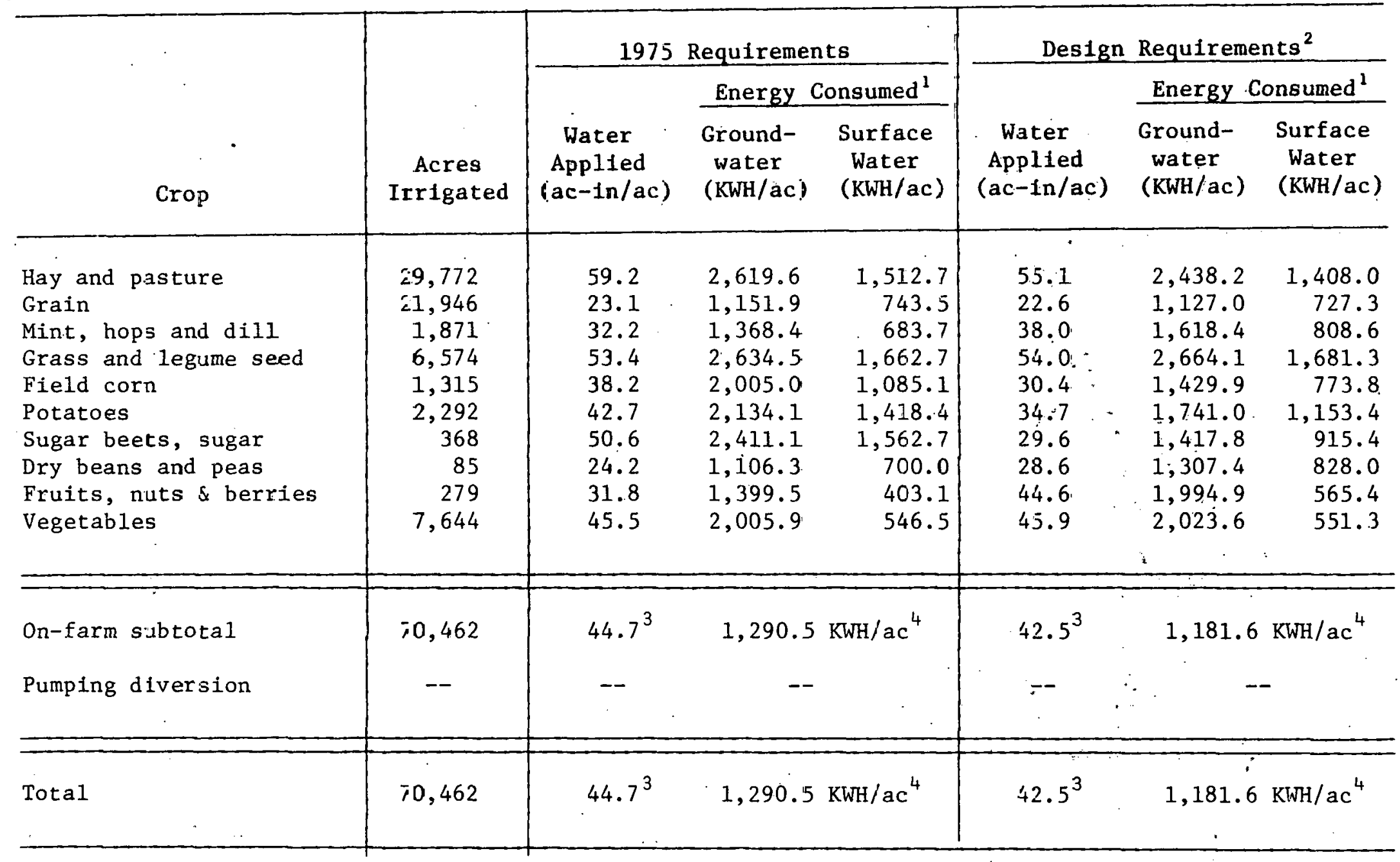

$185 \%$ of the water wias supplied by surface sources with average on-farn pumping lifts of 30 feet and the remaining 15\% from grour.Jwater with average lifts of 140 feet.

${ }^{2}$ Values represent the engineering sizing of water and energy required to provide a crop 8 years out of 10 .

${ }^{3}$ Average water consumed for all crops in subregton.

verage energy required for aIl crops and water sources in subarea. 
Approximately. 262,471 acre-feet of irrigation water were applied in 1975, which required 90,931.2 MWH of electricity. Engineering design requirements for the corresponding year were 249,553 acre-feet of water and 83,257.9 MWH of electricity. Since total engineering design values were less than actual applications, specific crop locations within this subarea were applying more water than necessary for optimum production. However, unique portions of the subarea had inadequate water availability for optimum productivity in 1975. Approximately 85 percent of the on-farm irrigation water was supplied from surface sources with 30 feet average Iifts; the remaining 15 percent was supplied from ground-. water with 140 feet average lifts. The area contains a Bureau of Reclamation project and several farmer-operated districts. Irrigation system types and their corresponding acreages were: side roll with 42,348 acres; hand move with 10,918 acres; center pivot with 9,239 acres; gravity with. 7,574 acres; solid set with 371 acres; and permanent with 12 acres.

\section{Northside Columbia Subarea}

This subarea lies entirely in south-central washington and includes parts of Skamania, Yakima, Klickitat and Benton Counties, Washington. The Columbia River forms the southern border from Kennewick on the eastern edge to south of Stevenson on the western edge. All major streams are in the western half of the subarea; the eastern half consists of dry grassy hills.

Table 28 lists the 1975 water and energy requirements for irrigation in the Northside Columbia subarea. A total of 79,000 acres was under irrigation with small grains, hay and pasture consuming 67 percent of the total acreage. 
Table 28. 1975 water requirements and energy consumption for irrigation in Northsidè Columbia Subarea.

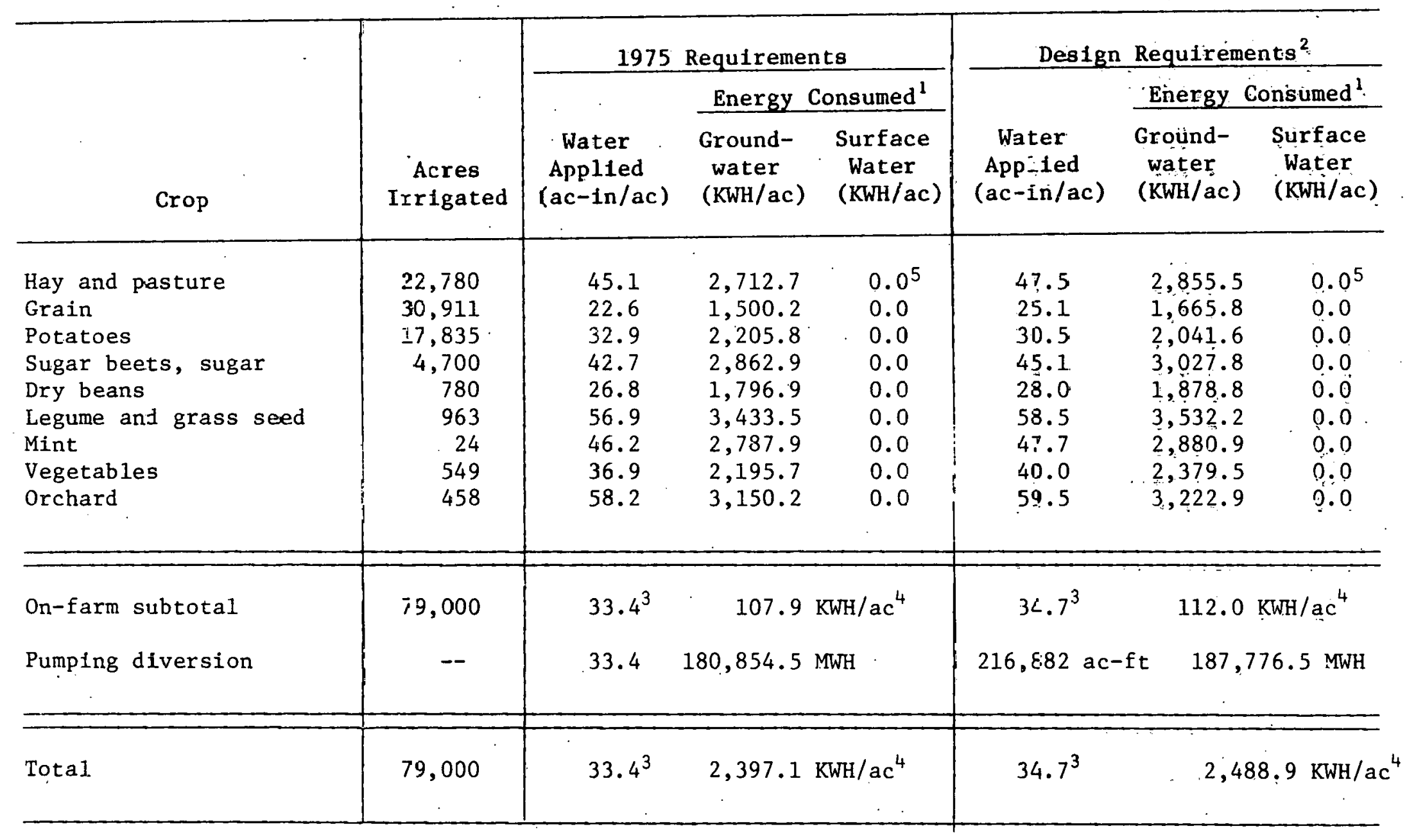

$195 \%$ of the water was supplied by surface sources. with average on-farm pumping lifts of 0 feet and the remaining 5\% from groundwater with average lifts of 200 feet.

2 Values represent the engineering sizing of water and energy required to provice a crop 8 years out of 10 .

${ }^{3}$ Average water consumed for all crops in subregion.

${ }^{4}$ Average energy reqlired for all crops and water sources in subarea.

' 11 surface water was supplied by pump diversion with 250 feet lifts and delivered the water in a ipeline for on-farm use. 
Almost 18,000 acres of potatoes were also irrigated, as were small acreages of sugar beets, dry beans, grass seeds, mint, vegetables and orchard crops.. This subarea also had 50,000 acres under center pivot irrigation systems.

The subarea had 219,883 acre-feet of water applied and used 189,370.9 MWH of electricity. The 1975 engineering design requirements were 228,442 acre-feet of water and 196,623.1 MWH of electricity. To reach surface elevations, water from groundwater sources (5 percent of total) had to be lifted 200 feet; 95 percent of the water was supplied from a pump diversion which lifted water 250 feet to a pressurized pipeline for on-farm operating pressures. The majority of the total acreage was under center pivot systems, with 50,240 acres. Additional acreages and systems were: 22,410 acres, side roll; 5,992 acres, hand move; 200 acres, drip; and 158 acres, permanent.

\section{Umatilla subarea}

Umatilla subarea is completely contained in northeastern oregon. The subarea extends northwest from the Blue Mountains to the Columbia River and includes the Umatilla River and Willow Creek Watersheds. Parts of Umatilla, Morrow and Gilliam counties are contained within this subarea. The economy is primarily agricultural.

Irrigation water requirements and energy consumption for 1975 in the Umatilla Subarea are listed in Table 29. Of the 156,803 acres which were irrigated, 61,563 acres contained hay and pasture. In addition, 47,21l acres of small grains and 25,717 acres of potatoes were irrigated. Other 
Table 29. 1975 water requirements and energy consumption of irrigation in the Umatilla Subarea.

\begin{tabular}{|c|c|c|c|c|c|c|c|}
\hline \multirow[b]{3}{*}{ Crop } & \multirow[b]{3}{*}{$\begin{array}{c}\text { Acres } \\
\text { I=rigated }\end{array}$} & \multicolumn{3}{|c|}{1975 Requirements } & \multicolumn{3}{|c|}{ Design Requirements ${ }^{2}$} \\
\hline & & \multirow[b]{2}{*}{$\begin{array}{c}\text { Water } \\
\text { Applied } \\
(a c-i n / a c)\end{array}$} & \multicolumn{2}{|c|}{ Energy Consumed ${ }^{1}$} & \multirow[b]{2}{*}{$\begin{array}{c}\text { Water } \\
\text { Applied } \\
(a c-1 n ; a c)\end{array}$} & \multicolumn{2}{|c|}{ Energy Consumed ${ }^{1}$} \\
\hline & & & $\begin{array}{l}\text { Ground- } \\
\text { water } \\
(\mathrm{KWH} / \mathrm{ac})\end{array}$ & $\begin{array}{l}\text { Surface } \\
\text { Water } \\
(\mathrm{KWH} / \mathrm{ac})\end{array}$ & & $\begin{array}{l}\text { Ground- } \\
\text { water } \\
\text { (KWH/ac) }\end{array}$ & $\begin{array}{l}\text { Surface } \\
\text { Water } \\
(\mathrm{KWH} / \mathrm{ac})\end{array}$ \\
\hline $\begin{array}{l}\text { Hay and pasture } \\
\text { Grain } \\
\text { Potatoes } \\
\text { Field corn } \\
\text { Legume seed } \\
\text { Grass seed } \\
\text { Mints, hops \& dill } \\
\text { Sugar beets, sugar } \\
\text { Dry beans and peas } \\
\text { Fruits, nuts \& ber } 2 \text { ies } \\
\text { Vegetables }\end{array}$ & $\begin{array}{r}61,563 \\
47,211 \\
25,717 \\
8,635 \\
2,223 \\
843 \\
513 \\
932 \\
3,515 \\
638 \\
5,013\end{array}$ & $\begin{array}{l}37.0 \\
23.3 \\
42.1 \\
38.5 \\
20.0 \\
12.4 \\
33.6 \\
50.6 \\
26.0 \\
29.4 \\
18.6\end{array}$ & $\begin{array}{r}1,698.3 \\
1,067.7 \\
1,979.4 \\
1,857.6 \\
838.1 \\
569.2 \\
1,287.6 \\
2,218.6 \\
1,169.0 \\
1,191.9 \\
797.6\end{array}$ & $\begin{array}{r}909.2 \\
764.1 \\
1,433.6 \\
1,251.6 \\
579.0 \\
408.6 \\
659.1 \\
1,563.1 \\
832.6 \\
467.6 \\
538.7\end{array}$ & $\begin{array}{l}52.5 \\
29.8 \\
33.7 \\
24.4 \\
39.2 \\
10.9 \\
41.9 \\
29.5 \\
20.4 \\
44.2 \\
22.7\end{array}$ & $\begin{array}{r}2,111.9 \\
1,347.1 \\
1,586.4 \\
1,128.0 \\
1,642.7 \\
555.0 \\
1,569.1 \\
1,303.5 \\
919.2 \\
1,583.4 \\
899.7\end{array}$ & $\begin{array}{r}1,124.4 \\
953.9 \\
1,147.0 \\
760.0 \\
1,134.9 \\
399.9 \\
803.2 \\
915.3 \\
651.2 \\
621.3 \\
646.3\end{array}$ \\
\hline $\begin{array}{l}\text { On-farm subtotal } \\
\text { Pumping diversion }\end{array}$ & $\begin{array}{c}156,803 \\
-\end{array}$ & $\begin{array}{c}32.6^{3} \\
233,018 \text { ac-ft }\end{array}$ & $\begin{array}{r}1,028.0 \\
151,976 .\end{array}$ & $\begin{array}{l}\mathrm{KWH} / \mathrm{ac}^{4} \\
\mathrm{MWH}\end{array}$ & $\begin{array}{c}38.7^{3} \\
199,966 a c-f t\end{array}$ & $\begin{array}{r}1,104.0 \\
+130,419\end{array}$ & $\mathrm{KWH} / \mathrm{ac}^{4}$ \\
\hline Total & 156,803 & $32.6^{3}$ & 1,997 & $\mathrm{KWH} / \mathrm{ac}^{4}$ & $38.7^{3}$ & $1,935.7$ & $\mathrm{KWH} / \mathrm{ac}^{4}$ \\
\hline
\end{tabular}

${ }^{1} 85.5 \%$ of the watez was supplied by surface sources. with average on-farm pumping lifts of $30 \mathrm{feet}$ and the remaining $14.5 \%$ from groundwater with average lifts of 115 feet.

2 Values represent the engineering sizing of water and energy requirec to provide a crop 8 years out of 10 .

${ }^{3}$ Average water consumed for all crops in subregion.

tverage energy required Eor all crops and water sources in subarea. 
irrigated crops included field corn, legume and grass seeds, mint, hops, dill, sugar beets, dry beans, peas, vegetables, fruits, nuts and berries.

The 156,803 acres of irrigated cropland had 425,981 acrefeet of water applied and used $167.0 \mathrm{MWH}$ of electricity, including diversion pumping of 233,018 acre-feet of water utilizing 151,976.5 MWH of electricity. Engineering design requirements were 505,689 acre-feet of water and 303,530.2 MWH of electricity. Average pumping lifts for surface sources, which supplied 85.8 percent of the water, were 30 feet, and 115 feet for groundwater sources.

In parts of this subarea, abundant water was available for irrigation and farmers in general used more than sufficient to produce a crop. However, in other portions, a water shortage existed and farmers irrigated until creeks were depleted; hay, pasture and small grains were produced in these areas. Center pivot and side roll were again the predominant systems with 71,614 and 57,625 acres, respectively. Additional systems were: gravity with 16,217 acres; hand move with 7,932 acres; solid set with 3,279 acres; big gun with 104 acres; and permanent with 32 acres.

\section{John Day Suharea}

John Day Subarea, in north-central oregon, contains the majority of Gilliam, Wheeler and Grant Counties. The area contains the John Day River drainage, a region with canyons, grass-covered hills and forested mountains. The economy is based primarily on agrinulture and forestry.

Table 30 contains the 1975 irrigation water and energy requirements of the John Day subarea. A total of 56,491 
Table 30. 1975 water requirements and energy consumption for irrigation in the John Day Subarea.

\begin{tabular}{|c|c|c|c|c|c|c|c|}
\hline \multirow[b]{3}{*}{ Crop } & \multirow[b]{3}{*}{$\begin{array}{c}\text { Acres } \\
\text { Irrigated }\end{array}$} & \multicolumn{3}{|c|}{ 1975. Requirements } & \multicolumn{3}{|c|}{ Destgn Requirements ${ }^{2}$} \\
\hline & & \multirow[b]{2}{*}{$\begin{array}{l}\text { Water } \\
\text { Applied } \\
(a c-i n / a c)\end{array}$} & \multicolumn{2}{|c|}{ Energy Consumed ${ }^{1}$} & \multirow[b]{2}{*}{$\begin{array}{c}\text { Water } \\
\text { Applied } \\
(\mathrm{ac}-\ln / \mathrm{ac})\end{array}$} & \multicolumn{2}{|c|}{ Energy Consumed ${ }^{1}$} \\
\hline & & & $\begin{array}{l}\text { Ground- } \\
\text { water } \\
\text { (KWH/ac) }\end{array}$ & $\begin{array}{l}\text { Surface } \\
\text { Water } \\
\text { (KWH/ac) }\end{array}$ & & $\begin{array}{l}\text { Ground- } \\
\text { water } \\
(\mathrm{KWH} / \mathrm{ac})\end{array}$ & $\begin{array}{l}\text { Surface } \\
\text { Water } \\
\text { (KWH/ac) }\end{array}$ \\
\hline $\begin{array}{l}\text { Hay and pasture } \\
\text { Grain } \\
\text { Potatoes } \\
\text { Mint, hops \& dill } \\
\text { Fruits, nuts \& berries } \\
\text { Garlic } \\
\text { Grass and legume seed } \\
\text { Unenumerated }\end{array}$ & $\begin{array}{r}45,445 \\
5,571 \\
522 \\
456 \\
70 \\
80 \\
214 \\
2,133\end{array}$ & $\begin{array}{l}38.4 \\
20.9 \\
24.0 \\
23.0 \\
28.5 \\
28.7 \\
27.2 \\
35.9\end{array}$ & $\begin{array}{l}976.1 \\
689.5 \\
872.8 \\
680.4 \\
877.3 \\
776.0 \\
675.2 \\
888.2\end{array}$ & $\begin{array}{l}275.3 \\
578.8 \\
773.2 \\
478.7 \\
760.0 \\
337.4 \\
189.0 \\
247.1\end{array}$ & $\begin{array}{l}42.2 \\
23.0 \\
26.4 \\
25.3 \\
31.4 \\
31.6 \\
29.9 \\
39.5\end{array}$ & $\begin{array}{r}1,073.7 \\
758.5 \\
960.0 \\
748.5 \\
965.0 \\
853.5 \\
743.1 \\
977.0\end{array}$ & $\begin{array}{l}302.8 \\
636.7 \\
850.5 \\
526.6 \\
836.0 \\
371.1 \\
208.2 \\
271.8\end{array}$ \\
\hline On-farm sibtotal & 56,491 & $35.9^{3}$ & 367.8 & $\mathrm{KWH} / \mathrm{ac}^{4}$ & $39.5^{3}$ & 404.6 & $\mathrm{KWH} / \mathrm{ac}{ }^{4}$ \\
\hline Pumping diversion & -- & -- & - & & -- & - & \\
\hline Total & 56,491 & $35.9^{3}$ & 367.8 & $\mathrm{KWH} / \mathrm{ac}^{4}$. & $39.5^{3}$ & 404.6 & $\mathrm{KWH} / \mathrm{ac}^{4}$ \\
\hline
\end{tabular}

$191.2 \%$ of on-farm water was pumped from surface sources with average pumping lifts of 20 feet and remaining from groundwater with 47 feet lifts.

${ }^{2}$ Values rəpresent the engineering sizirg of water and energy required to provile a crop 8 years out of 10.

${ }_{4}^{3}$ Average water consumed for all crops in subregion.

${ }^{4}$ Average energy recuired for all crops and water sources in subarea. 
acres was irrigated which included 46,445 acres of hay and pasture. Other irrigated crops included small grains, potatoes, mint, hops, dill, fruit, nuts, berries, garlic and grass seed.

The subarea had 169,000 acre-feet of water applied and used. 20,777 MWH of electricity in 1975. Engineering design requirements were 185,950 acre-feet of water and 22,856 MWH of electricity. over 91 percent of the water was supplied by surface sources with average pumping lifts of 20 feet; the remaining water was supplied from groundwater sources with 47 feet.average lifts.

The subarea does not contain large pumping diversions. However, informal non-profit ditch companies delivered part of the water to individual farmers. Gravity systems irrigated the majority of the acreage $(33,426$ acres). Of the pressurized systems, side roll, hand move, center pivot, permanent, and solid set irrigated $13,924,6,148,2,210$, 738 , and 45 acres, respectively.

\section{Deschutes subarea}

Deschutes subarea, located in central Oregon, includes parts of Sherman, Wasco, Jefferson, Crook, Deschutes, Klamath and Lake Counties. The western edge of this subarea borders on the Cascade Range. The Deschutes River and its major tributary, crooked River, provide high scenic and recreational opportunities ranging from forested mountains to deserts. The subarea contains several storage reservoirs on the Deschutes and Crooked Rivers. Warm Springs Indian Reservation is also entirely within the subarea and covers approximately a 35 square mile section extending from 
Deschutes River westward nearly to the crest of the Cascade Range。 The subarea's primary economic industries are agriculture, forestry and recreation.

The 1975 irrigable crops, water requirements and energy consumption for Deschutes Subarea are listed in Table 31. of the 186,033 acres under irrigation, 110,881 acres were in hay and pasture and 29,684 acres in small grains. The subarea also irrigated mint, hops, dill, garlic, grass seed, potatoes, field corn and legume seed. Total irrigated acreage required 635,613 acre-feet of water applied and 128,512 MWH of electricity in 1975. Corresponding engineering design requirements, 499,188 acre-feet of water and 101,407 MWH of electricity, were less than the actual requirements, indicating that some crops were over-irrigated. Over-irrigation resulted from a combination of soil conditions and management practices. Part of the area contained shallow, light textured soils with low water holding capacities. However, pump-back tail-water systems were used on 13,560 acres, resulting in extremely efficient water management.

Uver 96 percent of the 1rrigation water was supplied from surface sources with 17 feet average lifts, most of which came from Bureau of Reclamation projects. The remaining irrigation water was obtained from groundwater sources with 187 feet average lifts. In addition, water was periodically diverted from the Crooked River to supplement surface diversion from the Deschutes River.

Gravity irrigation was the largest single system, with 76,718 acres. Other systems included: 57,631 acres of side roll; 47,774 acres of hand move; 2,086 acres of center pivot; 1,185 acres of solid set; and 643 acres of big gun. 
Table 31. 1975 water requirements and energy consumption of irrigation in the Deschutes Subarea.

\begin{tabular}{|c|c|c|c|c|c|c|c|}
\hline \multirow[b]{3}{*}{ Crop } & \multirow[b]{3}{*}{$\begin{array}{c}\text { Acres } \\
\text { Irrigated }\end{array}$} & \multicolumn{3}{|c|}{1975 Requirements } & \multicolumn{3}{|c|}{ Design Requirements ${ }^{2}$} \\
\hline & & \multirow[b]{2}{*}{$\begin{array}{c}\text { Water } \\
\text { Applied } \\
(\mathrm{ac}-\mathrm{in} / \mathrm{ac})\end{array}$} & \multicolumn{2}{|c|}{ Energy Consumed ${ }^{1}$} & \multirow[b]{2}{*}{$\begin{array}{c}\text { Water } \\
\text { Applied } \\
(\mathrm{ac}-1 \mathrm{n} / \mathrm{ac})\end{array}$} & \multicolumn{2}{|c|}{ Energy Consumed ${ }^{l}$} \\
\hline & & & $\begin{array}{l}\text { Ground- } \\
\text { water } \\
(\mathrm{KWH} / \mathrm{ac})\end{array}$ & $\begin{array}{l}\text { Surface } \\
\text { Water } \\
(\mathrm{KWH} / \mathrm{ac})\end{array}$ & & $\begin{array}{l}\text { Ground- } \\
\text { water } \\
(\mathrm{KWH} / \mathrm{ac})\end{array}$ & $\begin{array}{c}\text { Surface } \\
\text { Water } \\
(\mathrm{KWH} / \mathrm{ac})\end{array}$ \\
\hline $\begin{array}{l}\text { Hay and pasture } \\
\text { Grain } \\
\text { Mints, hops and dill } \\
\text { Grass seed } \\
\text { Potatoes } \\
\text { Fleld corn } \\
\text { Legume seed } \\
\text { Garlic } \\
\text { Unenumerated }\end{array}$ & $\begin{array}{r}110,881 \\
29,684 \\
19,556 \\
10,147 \\
6,491 \\
308 \\
83 \\
78 \\
8,805\end{array}$ & $\begin{array}{l}48.4 \\
24.6 \\
33.4 \\
26.0 \\
46.4 \\
33.0 \\
33.0 \\
33.0 \\
33.0\end{array}$ & $\begin{array}{l}2,373.0 \\
1,185.7 \\
1,584.5 \\
1,071.0 \\
2,447.8 \\
-- \\
1,503.1 \\
1,732.3 \\
1,516.1\end{array}$ & $\begin{array}{r}763.4 \\
293.7 \\
537.1 \\
154.3 \\
1,245.8 \\
.0 .0 \\
446.9 \\
877.5 \\
450.7\end{array}$ & $\begin{array}{r}38.5 \\
26.8 \\
24.1 \\
8.8 \\
24.3 \\
22.9 \\
22.9 \\
22.9 \\
22.9\end{array}$ & $\begin{array}{r}1,887.6 \\
1,291.7 \\
1,143.3 \\
362.5 \\
1,281.9 \\
-- \\
1,043.1 \\
1,202.1 \\
1,052.1\end{array}$ & $\begin{array}{r}607.3 \\
320.0 \\
387.5 \\
52.2 \\
652.4 \\
0.0 \\
310.2 \\
608.9 \\
312.8\end{array}$ \\
\hline On-farm subtotal & 186,033 & $41.0^{3}$ & 682.0 & $\mathrm{KWH} / \mathrm{ac}^{4}$ & $32.2^{3}$ & 536.3 & $\mathrm{KWH} / \mathrm{ac}^{4}$ \\
\hline Pumping diversion. & -- & $6,714 a c-f t$ & 1,637 & $.5 \mathrm{MWH}$ & $6,714 \mathrm{ac}-\mathrm{ft}$ & 1,637 & $.5 \mathrm{MWH}$ \\
\hline Tota1 & 186,033 & $41.0^{3}$ & 690.80 & $\mathrm{KWH} / \mathrm{ac}^{4}$ & $32.2^{3}$ & 545.1 & $\mathrm{KWH} / \mathrm{ac}^{4}$ \\
\hline
\end{tabular}

${ }^{1} 96.5 \%$ of on-farm water was pumped from surface sources with average pumping lifts of 17 feet and remaining from groundwater with 187 feet lifts.

${ }^{2}$ Values represent the engineering sizing of water and energy required to provide a crop 8 years out of 10.

${ }^{3}$ Average water corsumed all crops in subregion.

${ }^{4}$ Average energy required for al- crops and water sources in subarea. 


\section{Hood Subarea}

Hood Subarea, in north-central Oregon, contains parts of HooG and Wasco Counties. It includes the south-side tributaries of the Columbia River between the Deschutes River and the crest of the Cascade Range. The area also includes Mt. Hood and the Columbia River Gorge. Agriculture and forestry are the principal industries.

The 1975 irrigated crops, water requirements and energy consumption are listed in Table 32 for Hood subarea. The subarea irrigated 26,785 acres; almost 20,000 acres of fruits, nuts and berries were included in this total. In addition, 5,823 acres of hay and pasture, plus small acreages of small grains and vegetables were irrigated.

In 1975, 50,892 acre-feet of water were applied and 31,512.6 MWH of electricity were consumed in Hood Subarea. Engineering design requirements were 62,722 acre-feet of water and $38,760.6 \mathrm{MWH}$ of electricity for 1975. Of the total irrigation water, 71.5 percent was supplied from surface sources with an average lift of 50 feet and the remaining from groundwater sources with average pumping lifts of 168 feet. Bureau of Reclamation projects supplied 8,021 acre-feet of water to 5,495 acres within the subarea.

This region was predominantly irrigated with pressurized irrigation systems. There were 21,601 acres nf hand move, 2,3.34 acres of permanent, 1,065 acrna of side rull, 419 acres of solid. set, 250 acres of center pivot, 162 acres of big gun, and 46 acres of drip. Gravity systems irrigated only 908 acres. 
Fable 32. $19 ; 5$ water requirements and energy consumption for irrigation in the Hood Subarea.

\begin{tabular}{|c|c|c|c|c|c|c|c|}
\hline \multirow[b]{3}{*}{ Crop } & \multirow[b]{3}{*}{$\begin{array}{c}\text { Acres } \\
\text { Irrigated }\end{array}$} & \multicolumn{3}{|c|}{1975 Requirements } & \multicolumn{3}{|c|}{ Design Requirements ${ }^{2}$} \\
\hline & & \multirow[b]{2}{*}{$\begin{array}{c}\text { Water } \\
\text { Applied } \\
(a c-1 n / a c)\end{array}$} & \multicolumn{2}{|c|}{ Energy Consumed ${ }^{1}$} & \multirow[b]{2}{*}{$\begin{array}{c}\text { Water } \\
\text { Applied } \\
(\mathrm{ac}-\mathrm{in} / \mathrm{ac})\end{array}$} & \multicolumn{2}{|c|}{ Energy Consumed ${ }^{1}$} \\
\hline & & & $\begin{array}{l}\text { Ground- } \\
\text { water } \\
(\mathrm{KWH} / \mathrm{ac})\end{array}$ & $\begin{array}{l}\text { Surface } \\
\text { Water } \\
(\mathrm{KWH} / \mathrm{ac})\end{array}$ & & $\begin{array}{l}\text { Ground- } \\
\text { water } \\
\text { (KWH/ac) }\end{array}$ & $\begin{array}{l}\text { Surface } \\
\text { Water } \\
\text { (KWH/ac) }\end{array}$ \\
\hline $\begin{array}{l}\text { Hay and pasture } \\
\text { Grain } \\
\text { Vegetables } \\
\text { Fruit, nuts \& berries }\end{array}$ & $\begin{array}{r}5,823 \\
887 \\
79 \\
19,996\end{array}$ & $\begin{array}{l}30.2 \\
11.0 \\
25.1 \\
21.2\end{array}$ & $\begin{array}{r}1,422.3 \\
603.6 \\
1,235.4 \\
1,044.5\end{array}$ & $\begin{array}{l}730.8 \\
388.7 \\
749.7 \\
634.5\end{array}$ & $\begin{array}{l}37.1 \\
13.5 \\
30.9 \\
26.1\end{array}$ & $\begin{array}{r}1,749.5 \\
742.5 \\
1,519.5 \\
1,284.7\end{array}$ & $\begin{array}{l}898.9 \\
478.1 \\
922.1 \\
780.4\end{array}$ \\
\hline $0_{n}$-farm subtotal & 26,785 & $22.8^{3}$ & 680.1 & $\mathrm{KWH} / \mathrm{ac}^{4}$ & $28.1^{3}$ & 836.6 & $\mathrm{KWH} / \mathrm{ac}^{4}$ \\
\hline Pumping diversion & -- & $8,021 a c-f t$ & 13,29 & $5 \mathrm{MWH}$ & $9,865 \mathrm{ac}-\mathrm{ft}$ & $16,3=$ & 2 MWH \\
\hline Total & 26,785 & $22.8^{3}$ & $1,176.5$ & $\mathrm{KWH} / \mathrm{ac}{ }^{4}$ & $28.1^{3}$ & $1,447.1$ & $\mathrm{KWH} / \mathrm{ac}^{4}$ \\
\hline
\end{tabular}

$171.5 \%$ of on-‡arm water was pumped from surface sources with average pumping 1ifts of 50 feet and remaining from groundwater with 168 feet lifts.

${ }^{2}$ Values represent the engineering sizing of water and energy required to provide a crop 8 years out of 10.

FAverage water consumed for all crops in subregion:

${ }^{L}$ Average energy required for all crops and water sources in subarea. 


\section{SUBREGTCIN 8}

Lower Columbia

This subregion lies in southwestern Washington and a small adjacent portion of oregon (see Figure 9). The region contains the drainage area along the northern section of the Columbia River from Bonneville Dam to the ocean with the crest of the Cascade Range as the eastern boundary; Clatskanie River Basin, which contains Rainier, Oregon, is also in this subregion. The area includes Clark, Cowlitz, and Wahkiakum Courlies, Washington, portions of Pacific, Lewis, Pierce, Skamania and Yakima Counties, Washington and Columbia county, Oregon.

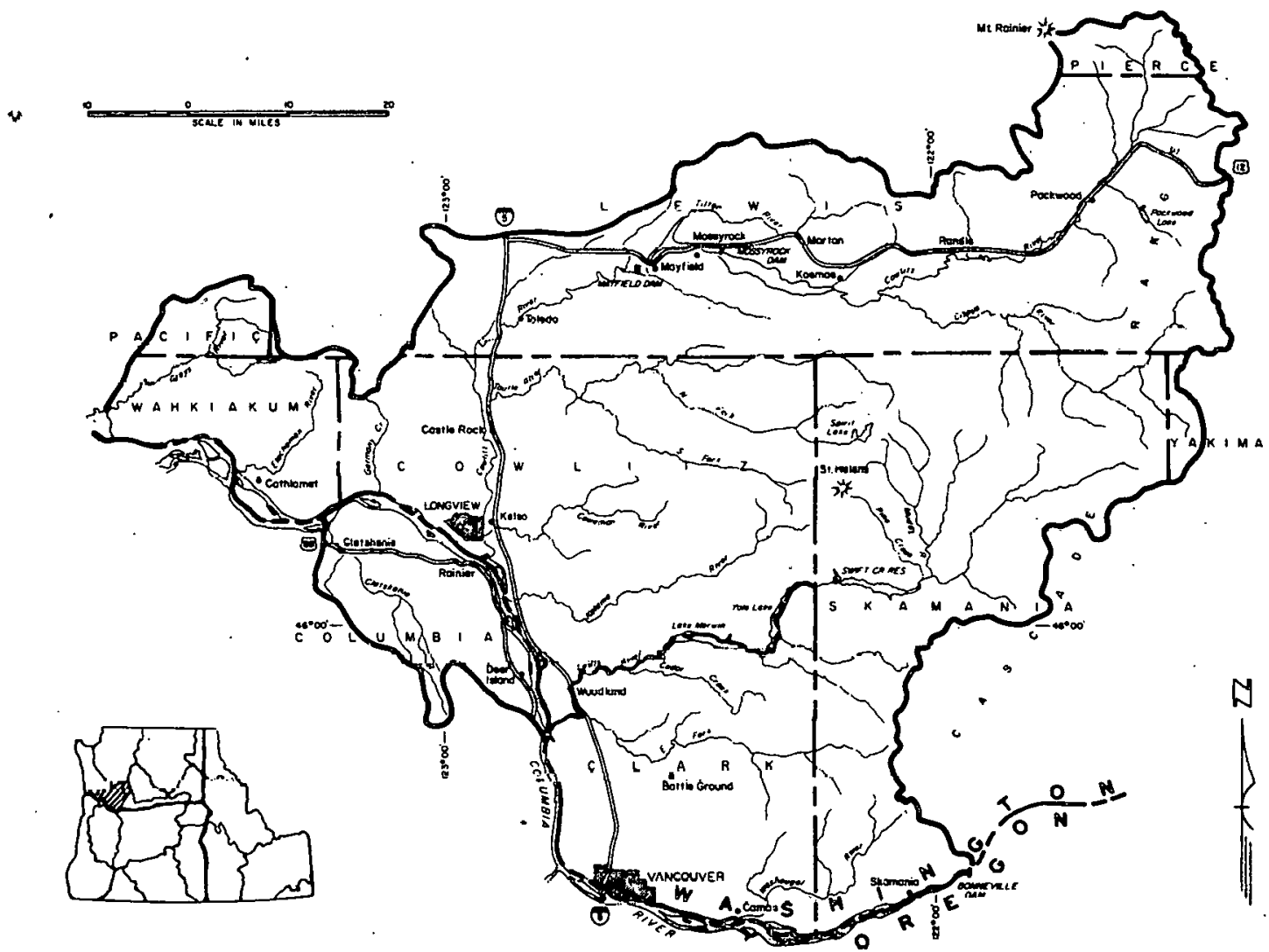

Figure 9. Map of Subregion 8 containing the Lower Columbia River Basin. 
The area, which is approximately 85 percent forest, supports a large paper, pulp and wood processing economy. The Columbia flood plain from Portland to the Pacific Ocean contains most of the agricultural lands of the subregion.

The 1975 irrigated crops, water requirements and energy consumption are listed in Table 33 for the Lower Columbia Subregion. Over 13,000 acres were irrigated: Hay and pasture were the largest irrigated crops, with 8,014 acres. All irrigation water was supplied by individual farmer or small farmer-operated irrigation districts; the area does not contain large diversion pumping plants.

The subregion had 23,362 acre-feet of water applied and used 9,0007 MWH of electricity for irrigation in 19.75. Of the 23,362 acre-feet, 49 percent was obtained from surface sources with average pumping lifts of 32 feet and the remaining 51 percent from groundwater with average lifts of 75 feet. The 1975 engineering design requirements were 27,056 acre-feet of water and 10,449 MWH of electricity.

Almost all of this subregion was irrigated with hand move systems $(11,607$ acres). The remaining acreage was under the following systems: 960 acres of side roll, 262 acres of big gur, 200 acres of drip, and 10 acres of solid set. 
Table 33. 1975 water requirements and energy consumption for irrigation in the Lower Columbia Subregion.

\begin{tabular}{|c|c|c|c|c|c|c|c|}
\hline \multirow[b]{3}{*}{ Crop } & \multirow[b]{3}{*}{$\begin{array}{c}\text { Acres } \\
\text { Irrigated }\end{array}$} & \multicolumn{3}{|c|}{1975 Requirements } & \multicolumn{3}{|c|}{ Design Requirements ${ }^{2}$} \\
\hline & & \multirow[b]{2}{*}{$\begin{array}{c}\text { Water } \\
\text { Applied } \\
(\mathrm{ac}-\mathrm{in} / \mathrm{ac})\end{array}$} & \multicolumn{2}{|c|}{ Energy Consumed ${ }^{1}$} & \multirow[b]{2}{*}{$\begin{array}{c}\text { Water } \\
\text { Applied } \\
(a c-i n / a c)\end{array}$} & \multicolumn{2}{|c|}{ Energy Consumed ${ }^{1}$} \\
\hline & & & $\begin{array}{l}\text { Ground- } \\
\text { water } \\
(\mathrm{KWH} / \mathrm{ac})\end{array}$ & $\begin{array}{l}\text { Surface } \\
\text { Water } \\
\text { (KWH/ac) }\end{array}$ & & $\begin{array}{l}\text { Ground- } \\
\text { water } \\
\text { (KWH/ac) }\end{array}$ & $\begin{array}{l}\text { Surface } \\
\text { Water } \\
\text { (KWH/ac) }\end{array}$ \\
\hline $\begin{array}{l}\text { Hay and pasture } \\
\text { Grain } \\
\text { Vegetables } \\
\text { Fruits, nuts \& berries } \\
\text { Potatoes } \\
\text { Mint, hofs \& dill } \\
\text { Unenumerated }\end{array}$ & $\begin{array}{r}8,014 \\
573 \\
2,651 \\
1,429 \\
61 \\
126 \\
185\end{array}$ & $\begin{array}{r}24.7 \\
4.0 \\
18.0 \\
17.5 \\
13.9 \\
21.3 \\
21.5\end{array}$ & $\begin{array}{l}883.4 \\
142.8 \\
630.9 \\
582.6 \\
487.2 \\
746.5 \\
819.3\end{array}$ & $\begin{array}{l}721.5 \\
116.6 \\
512.9 \\
467.5 \\
396.1 \\
606.9 \\
678.2\end{array}$ & $\begin{array}{r}28.1 \\
4.6 \\
20.9 \\
20.5 \\
16.1 \\
24.7 \\
24.9\end{array}$ & $\begin{array}{r}1,024.7 \\
165.7 \\
731.8 \\
675.9 \\
565.1 \\
866.0 \\
950.3\end{array}$ & $\begin{array}{l}836.9 \\
135.3 \\
595.0 \\
542.2 \\
459.5 \\
704.1 \\
786.7\end{array}$ \\
\hline On-farm subtotal & 13,039 & $21.5^{3}$ & 690.8 & $\mathrm{KWH} / \mathrm{ac}^{4}$ & $24.9^{3}$ & 801.4 & $\mathrm{KWH} / \mathrm{ac}^{4}$ \\
\hline Pumping diversion & -- & -- & - & - & -- & - & \\
\hline Total & 13,039 & $21.5^{3}$ & 690.8 & $\mathrm{KWH} / \mathrm{ac}^{4}$ & $24.9^{3}$ & 801.4 & $\mathrm{KWH} / \mathrm{ac}^{4}$ \\
\hline
\end{tabular}

$149 \%$ of the water was supplied by surface sources with average on-farm pumping 1 ifts of 32 feet and the remaining $51 \%$ from grour.dwater with average lifts of 75 feet.

${ }^{2}$ Values represent the engineering sizirg of water and energy required to frovide a crop of 8 years out of 10 .

${ }^{3}$ Average water consumed for all crops in subregion.

${ }^{4}$ Average energy reçuired for al1 crops and water sources in subregion. 
SUBREGION 9

willamette

The Willamette Subregion covers approximately 12,000 square miles and includes the Willamette and Sandy River drainage basins. The willamette River and its tributaries drain most of the subregion and join the Columbia River at Portland, Oregon. The river is the largest Columbia River tributary below Bonneville Dam. The subregion is bounded on the south by the Calapooya Mountains, on the north by the Columbia River, on the east by the Cascade Mountains and on the west by the Coast Range. The Willamette Valley contains about 3,500 square miles of gently sloping lands with an occasional butte (see Figure 10).

The Willamette Subregion irrigated 262,063 acres in 1975. The types of crops, water requirements and energy consumption for irrigation are listed in Table 34. High quality vegetable production, for which the subregion is world renowned, irrigated more acreage (83,576 acres) than any other crop. In addition to specialty crops, such as sugar. beet seed, grass seed, hops, mint and dill, the subregion irrigated traditional acreages of hay, pasture, grain and field corn.

The subregion had approximately 345;050 acre-feet of water applied and used 131,899.1 MWH. of electricity to irrigate all crops in 1975. The subregion's engineering design requirements for 1975 were about 419,301 acre-feet of water and $160,277.7$ MWH of electricity for the corresponding crops.

Individual farm irrigators predominate the subregion. There are, however, several small irrigation districts (less than 3,000 acres each) which are operated by farmers and 
Table 34. 1975 water requirements and energy consimption for frrigation in the Willamette Subregion.

\begin{tabular}{|c|c|c|c|c|c|c|c|}
\hline \multirow[b]{3}{*}{ Crop } & \multirow[b]{3}{*}{$\begin{array}{c}\text { Acres } \\
\text { Irrigated }\end{array}$} & \multicolumn{3}{|c|}{1975 Requirements } & \multicolumn{3}{|c|}{ Design Requirements ${ }^{2}$} \\
\hline & & \multirow[b]{2}{*}{$\begin{array}{c}\text { Water } \\
\text { Applied } \\
(a c-1 n / a c)\end{array}$} & \multicolumn{2}{|c|}{ Energy Consumed ${ }^{1}$} & \multirow[b]{2}{*}{$\begin{array}{c}\text { Water } \\
\text { Applied } \\
(\mathrm{ac}-1 \mathrm{n} / \mathrm{ac})\end{array}$} & \multicolumn{2}{|c|}{ Energy Consumed ${ }^{1}$} \\
\hline & & & $\begin{array}{l}\text { Ground- } \\
\text { water } \\
(\mathrm{KWH} / \mathrm{ac})\end{array}$ & $\begin{array}{l}\text { Surface } \\
\text { Water } \\
\text { (KWH/ac) }\end{array}$ & & $\begin{array}{l}\text { Ground- } \\
\text { water } \\
\text { (KWH/ac) }\end{array}$ & $\begin{array}{l}\text { Surface } \\
\text { Water } \\
\text { (KWH/ac) }\end{array}$ \\
\hline $\begin{array}{l}\text { Hay and pasture } \\
\text { Grain } \\
\text { Forage seed } \\
\text { Grass seed } \\
\text { Field corn } \\
\text { Potatoes } \\
\text { Fruits, nuts \& berries } \\
\text { Vegetables } \\
\text { Specilalty horticultu=al } \\
\text { Sugar beet, seed } \\
\text { Hops, mint \& dill } \\
\text { Unenumerated }\end{array}$ & $\begin{array}{r}67.488 \\
15.904 \\
9.535 \\
5.448 \\
13.250 \\
2.411 \\
11.277 \\
83.576 \\
8.905 \\
3.300 \\
23.869 \\
17.100\end{array}$ & $\begin{array}{r}23.3 \\
10.2 \\
0.3 \\
3.1 \\
10.0 \\
12.7 \\
14.6 \\
12.5 \\
28.3 \\
12.7 \\
15.3 \\
15.8\end{array}$ & $\begin{array}{l}817.5 \\
366.6 \\
327.5 \\
108.5 \\
367.9 \\
441.6 \\
509.4 \\
486.4 \\
994.9 \\
467.5 \\
541.0 \\
548.8\end{array}$ & $\begin{array}{r}632.9 \\
285.7 \\
253.8 \\
83.9 \\
293.4 \\
341.0 \\
392.9 \\
387.2 \\
770.7 \\
366.7 \\
.419 .7 \\
397.5\end{array}$ & $\begin{array}{r}28.2 \\
12.3 \\
11.6 \\
3.9 \\
12.5 \\
15.9 \\
18.3 \\
15.6 \\
35.4 \\
15.9 \\
15.8 \\
19.2\end{array}$ & $\begin{array}{r}989.5 \\
442.0 \\
408.5 \\
136.5 \\
459.9 \\
552.0 \\
638.4 \\
608.0 \\
1,244.5 \\
585.3 \\
558.6 \\
666.9\end{array}$ & $\begin{array}{l}766.0 \\
344.5 \\
316.5 \\
105.5 \\
366.7 \\
426.2 \\
492.5 \\
484.0 \\
964.0 \\
459.1 \\
433.4 \\
497.0\end{array}$ \\
\hline On-farm subtotal & 262.063 & $15.8^{3}$ & . 501.7 & $\mathrm{KWH} / \mathrm{ac}^{4}$ & $19.2^{3}$ & 609.6 & $\mathrm{KWH} / \mathrm{ac}^{4}$ \\
\hline Pumping diversion & -- & 2,820 ac $-f t$ & 422.0 & $46 \mathrm{MWH}$ & 3,427 ac $-f t$ & 512.8 & $35 \mathrm{MWH}$ \\
\hline Total & 262.063 & $15.8^{3}$ & 503.3 & $\mathrm{KWH} / \mathrm{ac}^{4}$ & $19.2^{3}$ & 611.6 & $\mathrm{KWH} / \mathrm{ac}{ }^{4}$ \\
\hline
\end{tabular}

$355 \%$ of on-farm water was pumped from surface sources with average pumping lifts of 20 feet and remain-

ing from groundwater with 72 Eeet lifts.

2 Values represent the engineering sizing of water and energy required to prcvide a crop 8 years out of 10 .

3 Average water consumed for all crops in subregion.

4 Average energy required for ali crops and water sources in subregion. 


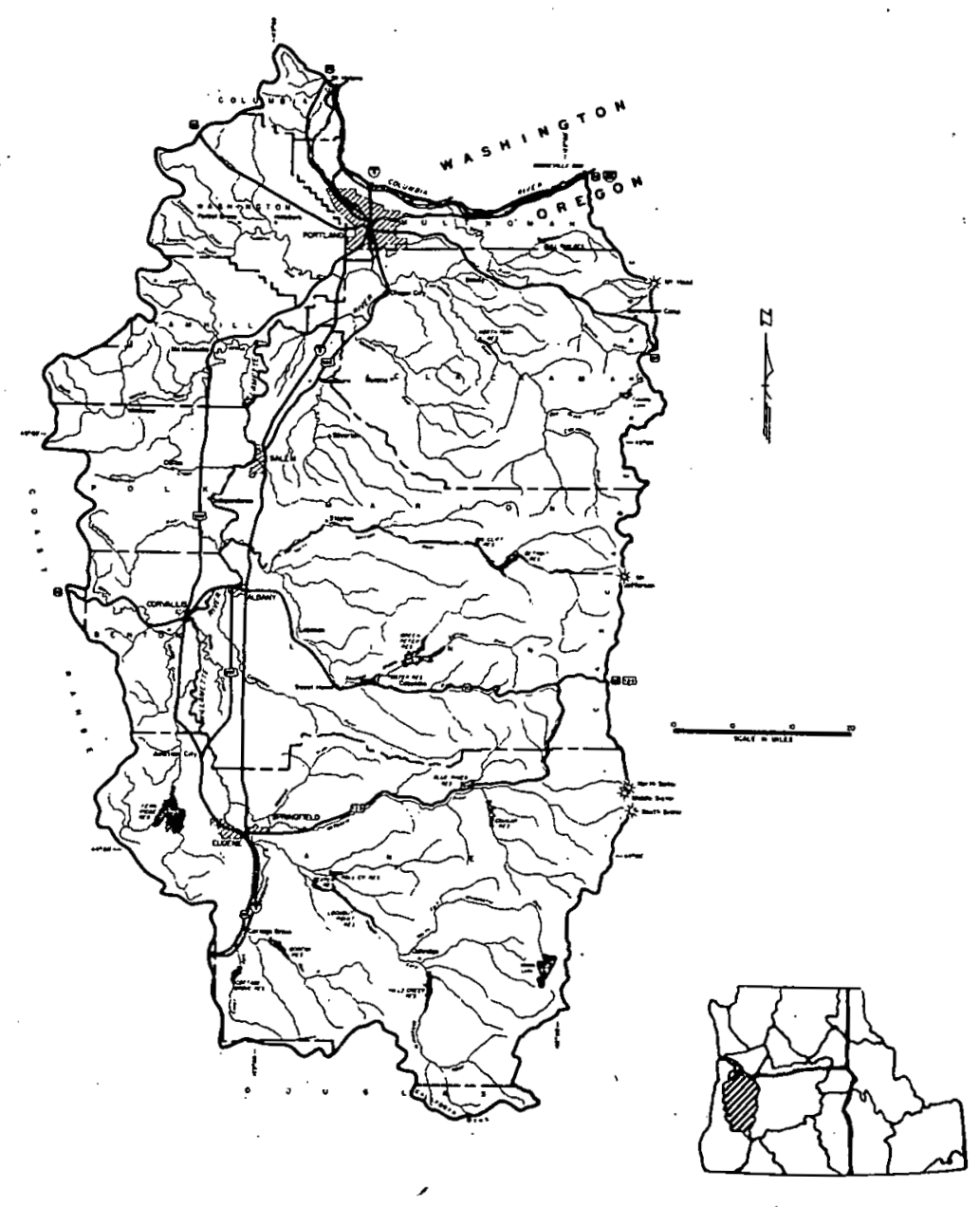

Figure 10. Map of Subregion 9 containing the willamette River Basin.

one Bureau of Reclamation project which irrigated 17,000 acres in 1975. Average pumping lifts from water source to field elevation are 72 and 20 feet for groundwater and surface water, respectively.

Seventy-four percent $(193,363$ acres) of the subregion was under hand move irrigation. The remaining systems and their corresponding acreages were: 37,566 acres, side roll; 21,164 acres, big gun; 5,698 acres, permanent; 2,679 acres, solid set; 1,456 acres, gravity; and 117 acres, drip. 
SUBREGION 10

Coastal

The Coastal subregion runs from the end of Washington's Olympic Peninsula to the California border, a distance of over 500 miles. The subregion contains approximately 24,000 square miles of which about 75 percent is in Oregon below the Columbia River.

The Coastal Sibregion has three unique sections: the coastal strip (including both oregon and Washington), the coastal mountain range, and the interior portion of two major river basins -- the Rogue and Umpqua. For this reason, the subregion has been divided into the following four subareas: Washington Coastal, Oregon Coastal, Umpqua and Rogue. Figure 11 presents the Washington Coastal Subareas and Figure 12 shows the locations of subareas within the oregon subregion.

The subregion contained approximately 114,500 acres of land under irrigation in 1975. The Rogue Subarea contained 56 percent of the total with Oregon Coastal, Umpqua and Washington coastal irrigating $23 ; 16.5$ and 4 percent of the subregion, respectively. In 1975, the subregion had 273,413 acre-feet of water applied and used 56,963.7 MWH of electricity for irrigation. The 1975 engineering design requirements for this subregion were 307,159 acre-feet of water and $64,859.3 \mathrm{MWH}$ of electricity.

Average pumping lifts ranged from 18 to 40 feet from surface sources to field elevations, which supplied water for over 98 percent of irrigated acreage. Groundwater provided the remaining 2 percent of the water with average lifts of 14 feet. 

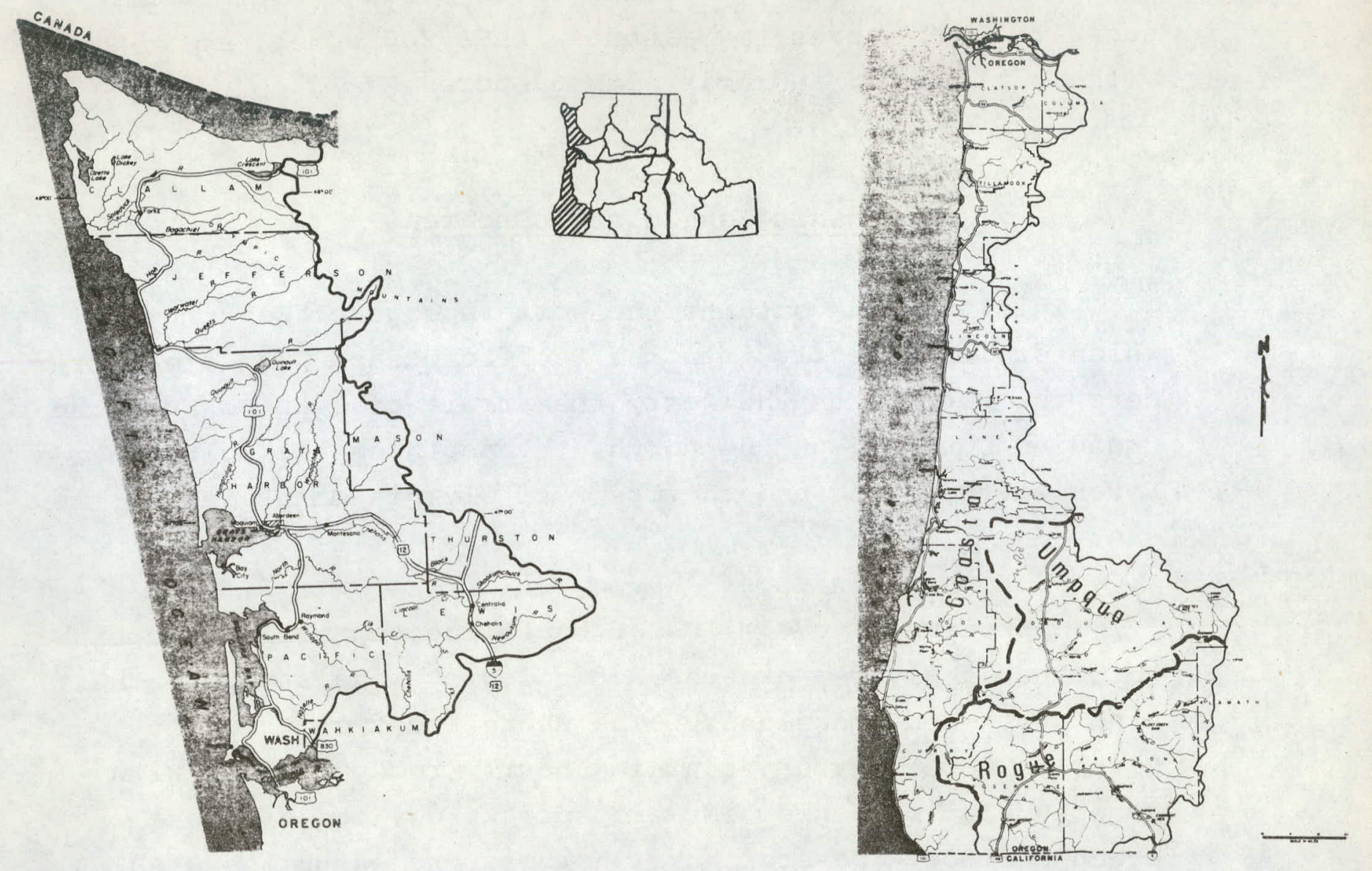

Figure 11. Partial Map of Subregion 10, containing the Washington Coastal Subarea.

Figure 12. Partial map of Subregion 10 , containing the oregon Coastal, Umpqua and Rogue Subareas.

A variety of crops required irrigation in this subregion. Hay and pastures, however, accounted for 80 percent of the acreage. Specialty crops, such as cranberries, were also irrigated on limited acreages. 
The major irrigation systems were hand move, gravity and side roll with $56,965,36,852$, and 10,495 acres, respectively. Additional systems and their acreages were: big gun with 5,679 acres; permanent with 3,203 acres; solid set with 1,211 acres; and drip with 67 acres.

\section{Washington Coastal Subarea}

This subarea contains the western edge of Washington, which drains directly into the Pacific Ocean. The area borders the Pacific on the west, the strait of Juan De Fuca and Canadian boundary on the north, the mouth of the Columbia River on the south and the crest of olympia Mountains on the east.

- Approximately 70 miles of coastline, from the Columbia to Quinault Rivers, are characterized by wide sandy beaches, sand dunes and grasslands. The shoreline from Quinault River to Cape Flattery contains narrow rocky beaches with steeply sloping banks. Numerous rocks dot the offshore ocean surface. Several bays, harbors and estuaries are contained in the subarea.

Irrigated crops, water requirements and energy consumption for 1975 in Washington Coastal subarea are listed in Table 35. Only 4,720 acres were irrigated in 1975 with approximately 75 percent of the irrigated land in hay and pasture. This subarea included only 4 percent of the irrigated area in the subregion. Hand move and solid set irrigation systems were the only two types used, with 3,790 and 930 acres; respectively. 
Table 35. 1975 water requirements and energy consumption for irrigation in the Washington Coastal Subarea.

\begin{tabular}{|c|c|c|c|c|c|c|c|}
\hline \multirow[b]{3}{*}{ Crop } & \multirow[b]{3}{*}{$\begin{array}{c}\text { Acres } \\
\text { Irrigated }\end{array}$} & \multicolumn{3}{|c|}{1975 Requirements } & \multicolumn{3}{|c|}{ Design Requirements ${ }^{2}$} \\
\hline & & \multirow[b]{2}{*}{$\begin{array}{c}\text { Water } \\
\text { Applied } \\
(\text { ac-in/ac) }\end{array}$} & \multicolumn{2}{|c|}{ Energy Consumed ${ }^{1}$} & \multirow[b]{2}{*}{$\begin{array}{c}\text { Water } \\
\text { Applied } \\
(\mathrm{ac}-\mathrm{in} / \mathrm{ac})\end{array}$} & \multicolumn{2}{|c|}{ Energy Consumed ${ }^{1}$} \\
\hline & & & $\begin{array}{l}\text { Ground- } \\
\text { water } \\
\text { (KWH/ac) }\end{array}$ & $\begin{array}{c}\text { Surface } \\
\text { Water } \\
(\mathrm{KWH} / \mathrm{ac})\end{array}$ & & $\begin{array}{l}\text { Ground- } \\
\text { water } \\
\text { (KWH/ac) }\end{array}$ & $\begin{array}{l}\text { Surface } \\
\text { Water } \\
\text { (KWH/ac) }\end{array}$ \\
\hline $\begin{array}{l}\text { Hay and pasture } \\
\text { Cranberries } \\
\text { Vegetables }\end{array}$ & $\begin{array}{r}3,490 \\
1,130 \\
100\end{array}$ & $\begin{array}{l}15.9 \\
21.4 \\
11.9\end{array}$ & $\begin{array}{l}-- \\
--\end{array}$ & $\begin{array}{l}436.1 \\
598.9 \\
326.4\end{array}$ & $\begin{array}{l}16.9 \\
22.7 \\
12.6\end{array}$ & $\begin{array}{l}-- \\
-- \\
--\end{array}$ & $\begin{array}{l}462.3 \\
634.8 \\
346.0\end{array}$ \\
\hline On-farm subtotal & 4,720 & $17.1^{3}$ & -- & $472.8 \mathrm{KWH} / \mathrm{ac}^{4}$ & $18.1^{3}$ & -- & $501.1 \mathrm{KWH} / \mathrm{ac}$ \\
\hline Pumping diversion & -- & -- & -- & -- & -- & -- & -- \\
\hline Total & 4,720 & $17.1^{3}$ & -- & $472.8 \mathrm{KWH} / \mathrm{ac}^{4}$ & $18.1^{3}$ & -- & $501.1 \mathrm{KWH} / \mathrm{ac}$ \\
\hline
\end{tabular}

${ }^{1} 100 \%$ of on-farm water was pumped from surface sources with average pumping lift of 25 feet.

2 Values represent the engineerirg sizing of water and energy required to provide a crop 8 years out of 10.

${ }^{3}$ Average water consumed for all crops in subregion.

${ }^{4}$ Average energy required for all crops and water sources in subarea. 
The subarea had 6,726 acre-feet of water applied and used 2,231.6 MWH of electricity in 1975. All water in this subarea was obtained from surface sources with an average pumping lift of 25 feet. The subarea!s engineering design requirements for 1975 were about 7,119 acre-feet of water and $2,364.7$ MWH of electricity.

\section{Oregon Coastal Subarea}

This subarea includes approximately 350 miles of Oregon coastline, shown in Figure 12, from the California-oregon border north to the Columbia River, bordering the Pacific Ocean on the west and the crest of the coast Range on the east. It contains all lands in oregon which drain directly into the Pacific Ocean, except the Rogue and Umpqua drainage areas. Fourteen major estuaries and several minor ones are located along the coastline.

Irrigated acreages are scattered throughout this subarea, but concentrations occur in the Tillamook area and in the Nehalem and Coquille drainage basins. These acreages have been developed by private enterprises.

Table 36 lists the 1975 water and energy requirements for the Oregon coastal subarea. Approximately 26,800 acres, 23 percent of the subregion's irrigated acreage, were irrigated in 1975 with 90 percent of this total in hay and pasture. Over 97 percent of the water was obtained from surface sources with average pumping. lifts of 18 feet; the remaining water was pumped from groundwater sources with average pumping lifts of 30 feet. 
Tajle 36. 1975 water requiremerts and energy consumption for irrigation in the Oregon Coastal Subarea.

\begin{tabular}{|c|c|c|c|c|c|c|c|}
\hline \multirow[b]{3}{*}{ Crop } & \multirow[b]{3}{*}{$\begin{array}{c}\text { Acres } \\
\text { Irrigated }\end{array}$} & \multicolumn{3}{|c|}{1975 Requirements } & \multicolumn{3}{|c|}{ Design Requirements ${ }^{2}$} \\
\hline & & \multirow[b]{2}{*}{$\begin{array}{c}\text { Water } \\
\text { Applied } \\
(a c-i n / a c)\end{array}$} & \multicolumn{2}{|c|}{ Energy Consumed ${ }^{1}$} & \multirow[b]{2}{*}{$\begin{array}{c}\text { Water } \\
\text { Applied } \\
(\mathrm{ac}-\mathrm{in} / \mathrm{ac})\end{array}$} & \multicolumn{2}{|c|}{ Energy Consumed ${ }^{1}$} \\
\hline & & & $\begin{array}{l}\text { Ground- } \\
\text { water } \\
(\mathrm{KWH} / \mathrm{ac})\end{array}$ & $\begin{array}{l}\text { Surface } \\
\text { Water } \\
\text { (KWH/ac) }\end{array}$ & & $\begin{array}{l}\text { Ground- } \\
\text { water } \\
(\mathrm{KWH} / \mathrm{ac})\end{array}$ & $\begin{array}{l}\text { Surface } \\
\text { Water } \\
(\mathrm{KWH} / \mathrm{ac})\end{array}$ \\
\hline $\begin{array}{l}\text { Hay and pastur } \\
\text { Cranberries } 5 \\
\text { Fruits, nuts \& berries } \\
\text { Field corn } \\
\text { Potatoes } \\
\text { Vegetables } \\
\text { Specialty horticultural } \\
\text { Unenumerated }\end{array}$ & $\begin{array}{r}24,017 \\
930 \\
90 \\
500 \\
57 \\
72 \\
165 \\
962\end{array}$ & $\begin{array}{r}19.6 \\
22.0 \\
6.0 \\
12.8 \\
8.1 \\
12.8 \\
22.0 \\
19.4\end{array}$ & $\begin{array}{l}569.5 \\
455.1 \\
171.9 \\
416.2 \\
228.3 \\
360.8 \\
602.6 \\
546.9\end{array}$ & $\begin{array}{r}.533 .0 \\
414.9 \\
160.9 \\
392.9 \\
. \quad 213.5 \\
.337 .4 \\
562.4 \\
511.4\end{array}$ & $\begin{array}{r}22.3 \\
23.9 \\
6.8 \\
14.6 \\
9.2 \\
14.6 \\
25.1 \\
22.1\end{array}$ & $\begin{array}{l}649.2 \\
494.4 \\
195.9 \\
474.4 \\
260.3 \\
411.4 \\
687.0 \\
623.5\end{array}$ & $\begin{array}{l}608.3 \\
450.9 \\
183.4 \\
447.9 \\
243.4 \\
384.7 \\
641.2 \\
583.0\end{array}$ \\
\hline On-farm subtotal & 26,763 & $19.4^{3}$ & 524.9 & $\mathrm{KWH} / \mathrm{ac}^{4}$ & $22.1^{3}$ & 597.6 & $\mathrm{KWH} / \mathrm{ac}^{4}$ \\
\hline Pumping diversion & -- & -- & - & & -- & -- & \\
\hline Total & 26,763 & $19.4^{3}$ & 524.9 & $\mathrm{KWH} / \mathrm{ac}^{4}$ & $22.1^{3}$ & 597.6 & $\mathrm{KWH} / \mathrm{ac}^{4}$ \\
\hline
\end{tabular}

$197.4 \%$ of the water was supplied by surface sources with average on-farm pumping lifts of 18 feet and the remaining $2.6 \%$ from groundwater with average lifts of 30 feet.

2 Values represent the engineering sizing of water and energy required to provide a crop 8 years out of 10 .

${ }^{3}$ Average water consumed for all crops in subregion.

${ }^{4}$ Average energy required for all crops and water sources in subarea.

In addition to water for moisture deficit, 700 acres required water for flood harvesting; the reported value includes these water and energy requirements. 
The Oregon Coastal Subarea had 43,267 acre-feet of water applied and used 14,048 MWH of electricity in 1975. The 1975 engineering design requirements were approximately 49,288 acre-feet of water and 15,994 MWH of electricity.

Hand move systems dominated, with 24,770 acres. Big gun, permanent and solid set also irrigated 1,019,683 and 281 acres, respectively.

\section{Umpqua subared}

The Umpqua Subarea is positioned directly south of the Willamette subregion and just north of the Rogue subarea. The subarea drains into the Pacific Ocean via the Umpqua River, which crosses the Oregon Coastal subarea. The subarea is contained in Douglas County and includes the town of Roseburg, the principal population center.

Elevation of agricultural regions within the subarea ranges from 100 to 2,000 feet and the growing season averages from 180 to 200 days. The subarea is a major timber and sheep producing area in Oregon.

Table 37 contains the irrigated.crops and their water and energy requirements for the Umpqua subarea in 1975. Of the 18,911 irrigated acres, hay and pasture were the primary irrigated crop ( 85 percent of total). The subarea irrigated approximately 1,100 acres of grain and field corn; in addition, a few acres of specialty crops like sugar beet seed, mint and dill also required irrigation.

This subarea contained 16.5 percent of the total subregion's irrigated acreage. In 1975, the subarea had 35,458 acre-feet of water applied and consumed 13,604 MWH of electricity. 
Tajle 37. 1975 water requiremerts and energy consumption for irrigation in the Umpqua Subarea.

\begin{tabular}{|c|c|c|c|c|c|c|c|}
\hline \multirow[b]{3}{*}{ Crop } & \multirow[b]{3}{*}{$\begin{array}{c}\text { Acres } \\
\text { Irrigated }\end{array}$} & \multicolumn{3}{|c|}{1975 Requirements } & \multicolumn{3}{|c|}{ Des1gn Requirements ${ }^{2}$} \\
\hline & & \multirow[b]{2}{*}{$\begin{array}{c}\text { Water } \\
\text { Applied } \\
(a c-1 n / a c)\end{array}$} & \multicolumn{2}{|c|}{ Energy Consumed ${ }^{1}$} & \multirow[b]{2}{*}{$\begin{array}{c}\text { Water } \\
\text { Applied } \\
(\mathrm{ac}-\mathrm{in} / \mathrm{ac})\end{array}$} & \multicolumn{2}{|c|}{ Energy Consumed ${ }^{1}$} \\
\hline & & & $\begin{array}{l}\text { Ground- } \\
\text { water } \\
(\mathrm{KWH} / \mathrm{ac})\end{array}$ & $\begin{array}{l}\text { Surface } \\
\text { Water } \\
\text { (KWH/ac) }\end{array}$ & & $\begin{array}{l}\text { Ground- } \\
\text { water } \\
(\mathrm{KWH} / \mathrm{ac})\end{array}$ & $\begin{array}{l}\text { Surface } \\
\text { Water } \\
\text { (KWH/ac) }\end{array}$ \\
\hline $\begin{array}{l}\text { Hay and pasture } \\
\text { Grain } \\
\text { Field corn } \\
\text { Potatoes } \\
\text { Fruits, nuts \& berries } \\
\text { Hops, mints \& dill } \\
\text { Vegetables } \\
\text { Sugar beet seed }\end{array}$ & $\begin{array}{r}16,100 \\
740 \\
360 \\
5 \\
832 \\
100 \\
754 \\
20\end{array}$ & $\begin{array}{r}24.1 \\
11.2 \\
18.5 \\
20.4 \\
23.3 \\
24.0 \\
8.5 \\
13.5\end{array}$ & $\begin{array}{l}741.7 \\
291.3 \\
696.4 \\
522.2 \\
579.2 \\
632.7 \\
217.9 \\
345.6\end{array}$ & $\begin{array}{l}767.4 \\
303.3 \\
767.3 \\
544.0 \\
604.1 \\
658.3 \\
227.0 \\
360.0\end{array}$ & $\begin{array}{l}30.6 \\
14.2 \\
23.5 \\
25.8 \\
29.5 \\
30.4 \\
10.8 \\
17.1\end{array}$ & $\begin{array}{l}941.9 \\
370.0 \\
884.4 \\
663.2 \\
735.6 \\
803.5 \\
276.7 \\
438.9\end{array}$ & $\begin{array}{l}974.5 \\
385.2 \\
974.5 \\
690.9 \\
767.3 \\
836.0 \\
288.3 \\
457.2\end{array}$ \\
\hline Or-farm subtotal & 18,911 & $22.5^{3}$ & 719.4 & $\mathrm{KWH} / \mathrm{ac}^{4}$ & $29.0^{3}$ & 913.5 & $\mathrm{KWH} / \mathrm{ac}^{4}$ \\
\hline Pumping diversion & -- & -- & & -- & -- & & -- \\
\hline Total & 18,911 & $22.5^{3}$ & 719.4 & $\mathrm{~K}: \mathrm{NH} / \mathrm{ac}^{4}$ & $29.0^{3}$ & 913.5 & $\mathrm{KWH} / \mathrm{ac}^{4}$ \\
\hline
\end{tabular}

$199.6 \%$ of the water was supplied by surface sources with average on-farm pumping lifts of 20 feet and. the remaining $0.4 \%$ from groundwater with average lifts of 13 feet.

${ }^{2}$ Values represent the engineering sizing of water and energy required to provide a crop 8 years out of 10 .

${ }^{3}$ kverage water consumed for all crops in subregion.

${ }^{4}$ Average energy required for all crops and water sources in subarea. 
Engineering design requirements for 1975 were 45,700 acrefeet of water and 17,275 MWH of electricity. Approximately 99.6 percent of the water for irrigation was obtained from surface sources with average lifts of 20 feet; groundwater sources with average lifts of 13 feet supplied the remaining fraction ( 0.4 percent) of water.

Side roll, with 10,495 acres, was the predominant system. Other systems employed included 4,8.06 acres of hand move, 3,210 acres of big gün, 350 acres of gravity; and 50 aorè of drip.

\section{Rogue Subarea}

This subarea is located in the southeastern corner of Oregon and borders the California-oregon boundary. It is drained by the Rogue River and its tributaries, which are contained within Jackson, Josephine and Curry Counties; Medford, Ashland and Grants Pass are the major towns. The subarea extends in a broad crescent from south of Ashland through Grants Pass to Cave Junction. About 75 percent of the Rogue subarea is forested; forest products are the subarea's major economic industry. Agriculture ranks second to forestry in economic importance; pears, apples and peaches are primary agricultural products.

The irrigated crops, water requirements and energy consumption for 1975 in Rogue subarea are shown in Table 38 . over 64,000 acres were irrigated, accounting for 56 percent of the subregion's total. About 30,000 acres were furnished water via irrigation districts. Of this, a total of 7,904 acre-feet of water was relifted using 1,127.4 MWH of electricity. Again, hay and pasture were the major irrigated 
Table 38. 1975 water requirements and energy consumption for irrigation in the Rogue Subarea.

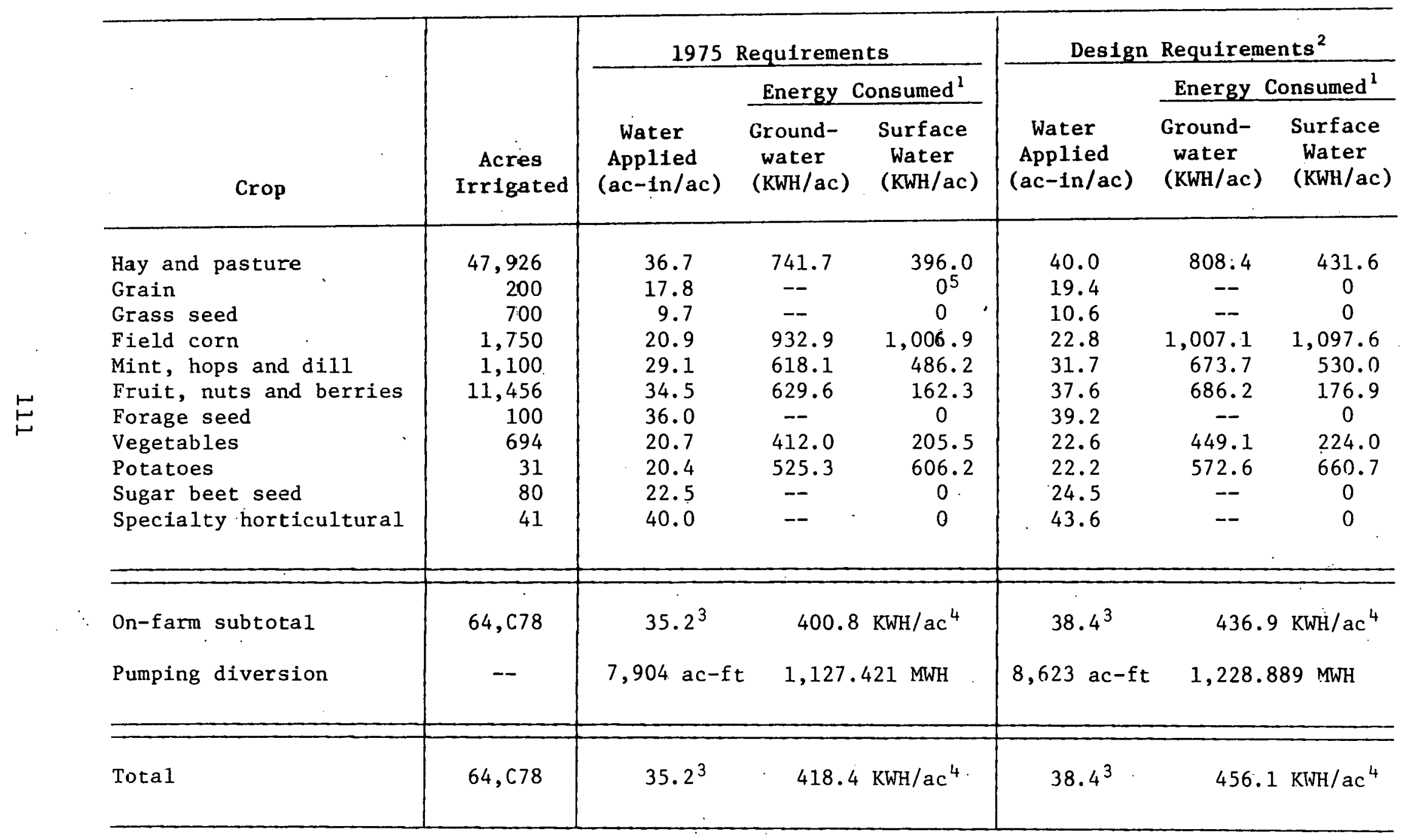

$199 \%$ of the water was supplied by surface sources with average on-farm pumping lifts of 40 feet and the remaining $1 \%$ from groundwater with average lifts of 14 feet.

${ }^{2}$ Values represent the engineering sizing of water and energy required to provide a crop 8 years out of 10 .

3 Average water consumed for all crops in subregion.

${ }^{4}$ Average energy required for all crops and water sources in subarea.

${ }^{5}$ Zero energy value results from use of surface (gravity) irrigation system without pumping requirements. 
crops (75 percent of total irrigated acreage). The subarea also irrigated a variety of specialty crops.

Approximately 188,000 acre-feet of water were applied and $26,810.2 \mathrm{MWH}$ of electricity were used in 1975 to satisfy the subarea's irrigation needs. The engineering design requirements for 197.5 were 205,050 acre-feet of water and 29,226.0 MWH of electricity. Over 99 percent of the on-farm water was supplied by surface sources with average pumping lifts of 40 feet; the remaining water was pumped from groundwater sources with average lifts of 14 feet.

Gravity systems, with 36,502 acres, irrigated 57 percent of the subarea. In addition, hand move irrigated 23,599 acres ( 37 percent) with permanent and big gun irrigating 2,520 and 1,450 acres, respectively. 
SUBREGION 11

Puget sound

The Puget Sound Subregion is located in the northwestern part of Washington. The area includes all lands south of the Canadian border that are drained by streams flowing into Puget Sound, Hood Canal, Georgia Strait, and that portion of the Strait of Juan De Fuca east from and including the Elwha River (see Figure 13). The area encompasses approximately $8,500,000$ acres and includes parts of Whatcom, Skagit, Nohomish, King, Pierce, Lewis, Thurston, Mason, Kitsap, Jefferson, Clallam and San Juan Counties. Nine river basins and two island groupings comprise the major part of the Puget Sound tributary drainage.

The Puget Sound Subregion contains some of the most secluded and rugged, forested mountains along both its eastern and western boundaries. Forests cover approximately 76 percent of the land; however, agriculture, forest products and fishing account for only about 3 percent of the employment. The area contains over 2 million people who are primarily employed in manufacturing, retail trade and professional services.

Table 39 contains 1975 irrigated crops, water requirements and energy consumption for Puget Sound Subregion. The subregion contains 92,132 acres of irrigation with hay and pastures comprising 64,072 acres. Vegetable crops were also irrigated on 20,428 acres.

The subregion had an application of 185,799 acre-feet of water and consumed 69,559 MWH of electricity in 1975 for irrigation. of the of the total water required, 72.8 percent was supplied from surface sources with average pumping lifts of 25 feet; the remaining 
Table 39. 1975 water requirements and Energy consumption for irrigation in the Puget Sound Subregion.

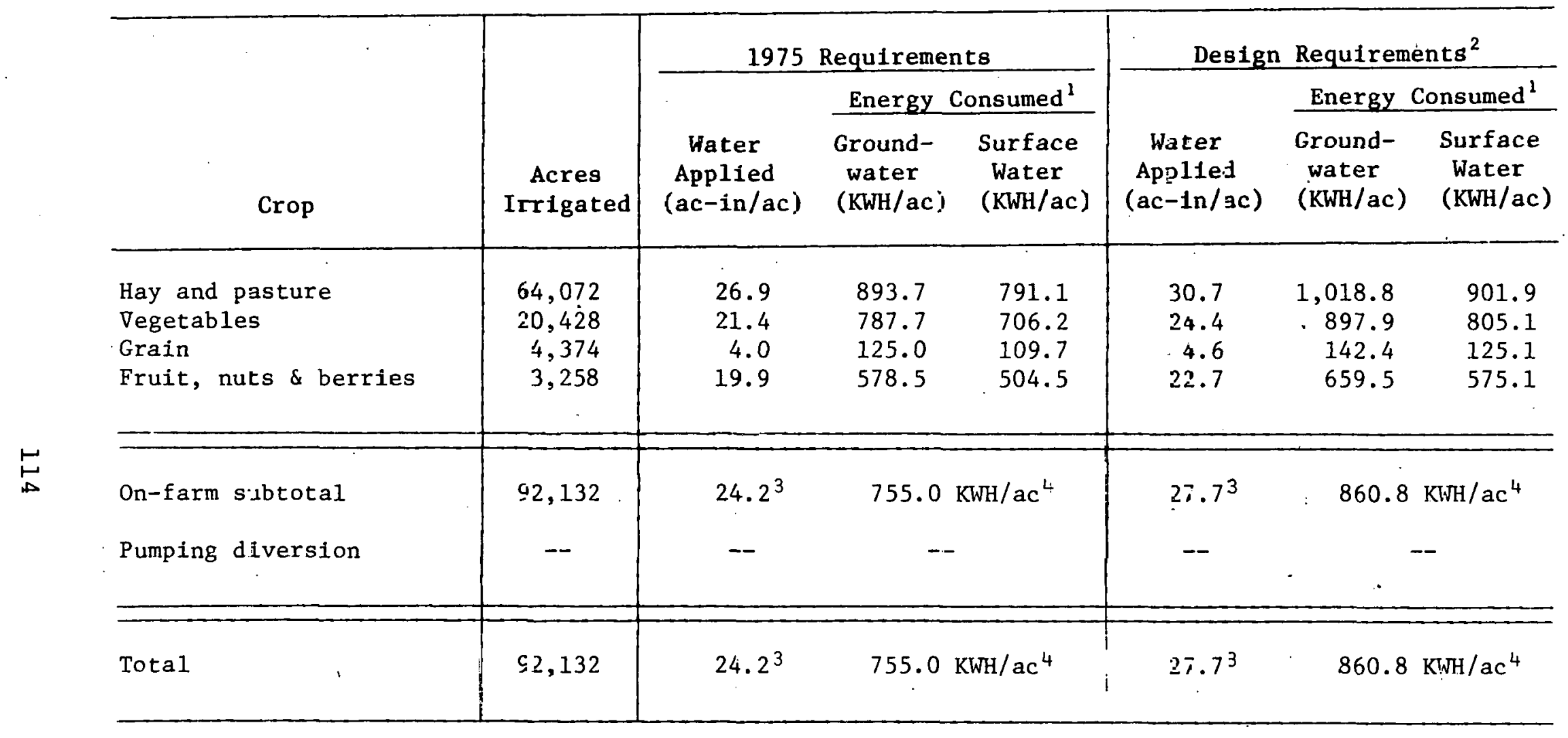

$172.8 \%$ of the water was supplied by surfaze sources with arerage on-farm pumping 1 ifts of 25 feet and the remaining $27.2 \%$ from groundwater witi average lifts of 50 feet.

${ }^{2}$ Values represent the engineering sizing of water and energy required to prcvide a crop 8 years out of 10 .

${ }^{3}$ Average water consumed for ail crops in subregion.

${ }^{4}$ Average energy required for all crops and water sources in subregion. 


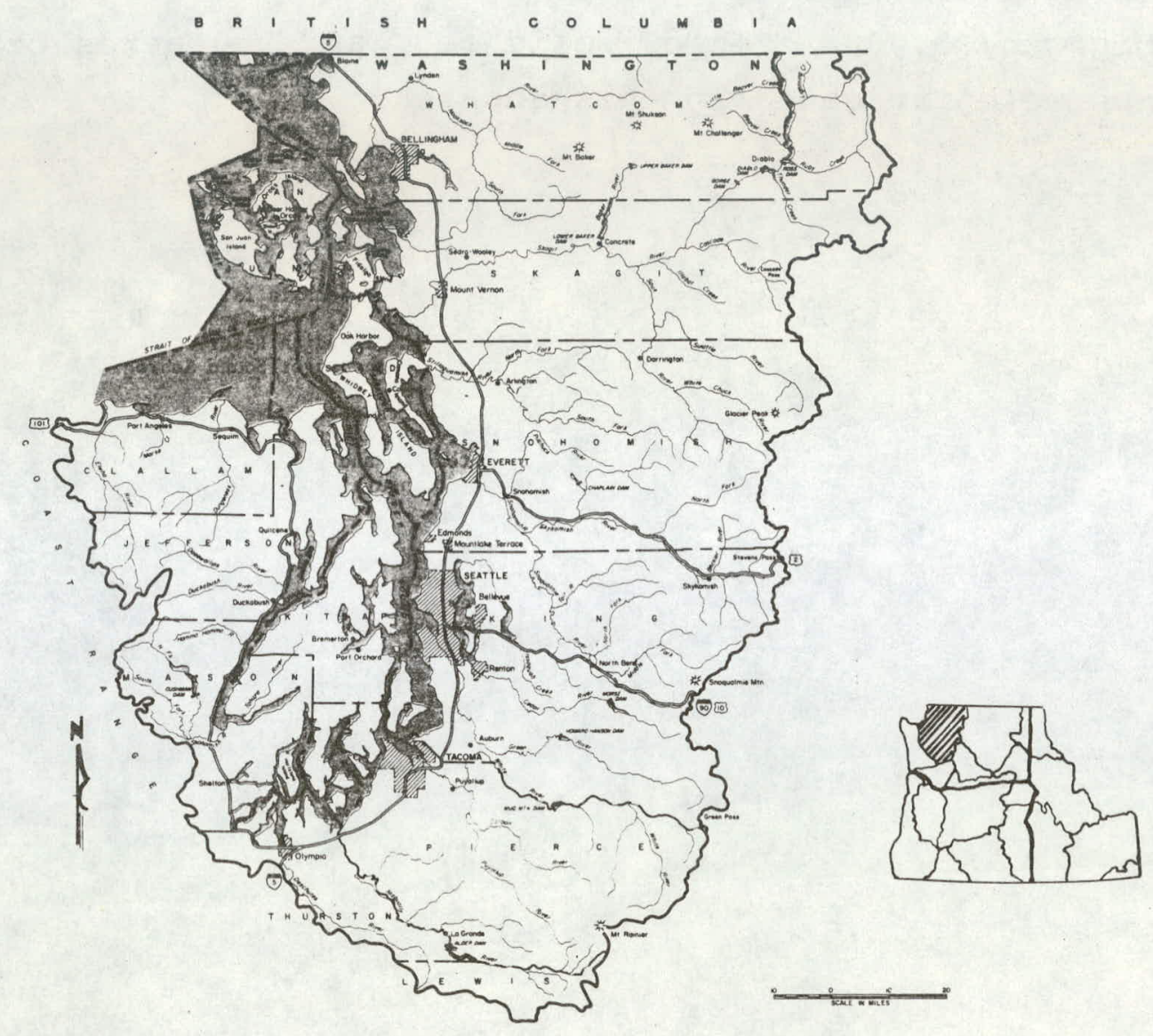

Figure 13. Map of Subregion 11 containing Puget Sound subarea.

27.2 percent was obtained from groundwater sources with average lifts of 50 feet. The 1975 engineering design requirements were 212,671 acre-feet of water and 79,307 MWH of electricity.

All irrigation water was obtained by individual farmer operations. The subregion does not contain irrigation districts with pump diversions on Bureau of Reclamation 
projects. All irrigation was pressurized, with hand move systems irrigating 58,632 acres in 1975 (64 percent of the total). In addition, 18,000 acres of side roll, 10,000 acres of big gun, 5,000 acres of solid set, and 500 acres of drip systems were irrigated in this subarea. 
SUBREGION 12

Oregon Closed Basin

This subregion encompasses. a closed basin in southcentral oregon, which contains approximately 17,900 square miles. The area includes most of Harney and Lake Counties, plus fractions of Deschutes, Klamath and Malheur Counties and is shown in Figure 14. The closed Basin is the northwest extension of the Great Basin geologic province and has many of its prominent features, such as fault block mountains. The most rugged parts of the subregion include the steens Mountains in the southeast, the mountainous area south and west of Abert and Summer Lakes, and the southern part of the Blue Mountains in the northeast. All streams in the subregion empty into internal lakes. Occasional buttes, cinder cones, gulleys, broken lava flows and surrounding mountains relieve what otherwise is a flat vista of rangeland. Over three-fourths of the subregion is occupied by range. Forestry and agriculture are the two major economic contributors to the subregion, with agriculture's primary emphasis on rangeland livestock production.

The subregion experiences climatic extremes; summers are warm with recorded temperatures as high as $109^{\circ} \mathrm{F}$, while winters are long and cold with record lows of $-50^{\circ} \mathrm{F}$. There is no real frost-free season and freezing temperatures may occur in any month, but in farming areas growing seasons vary from 90-120 days. Precipitation in the agricultural areas annually ranges from 7 to 12 inches.

To facilitate data presentation, this subregion is partitioned into three closed subareas: Fort Rock - Christmas Lake - Chewaucan, Silvies - Silver - Donner und Blitzen, and Alvord - Catlow - Warner (see Figure 14). 


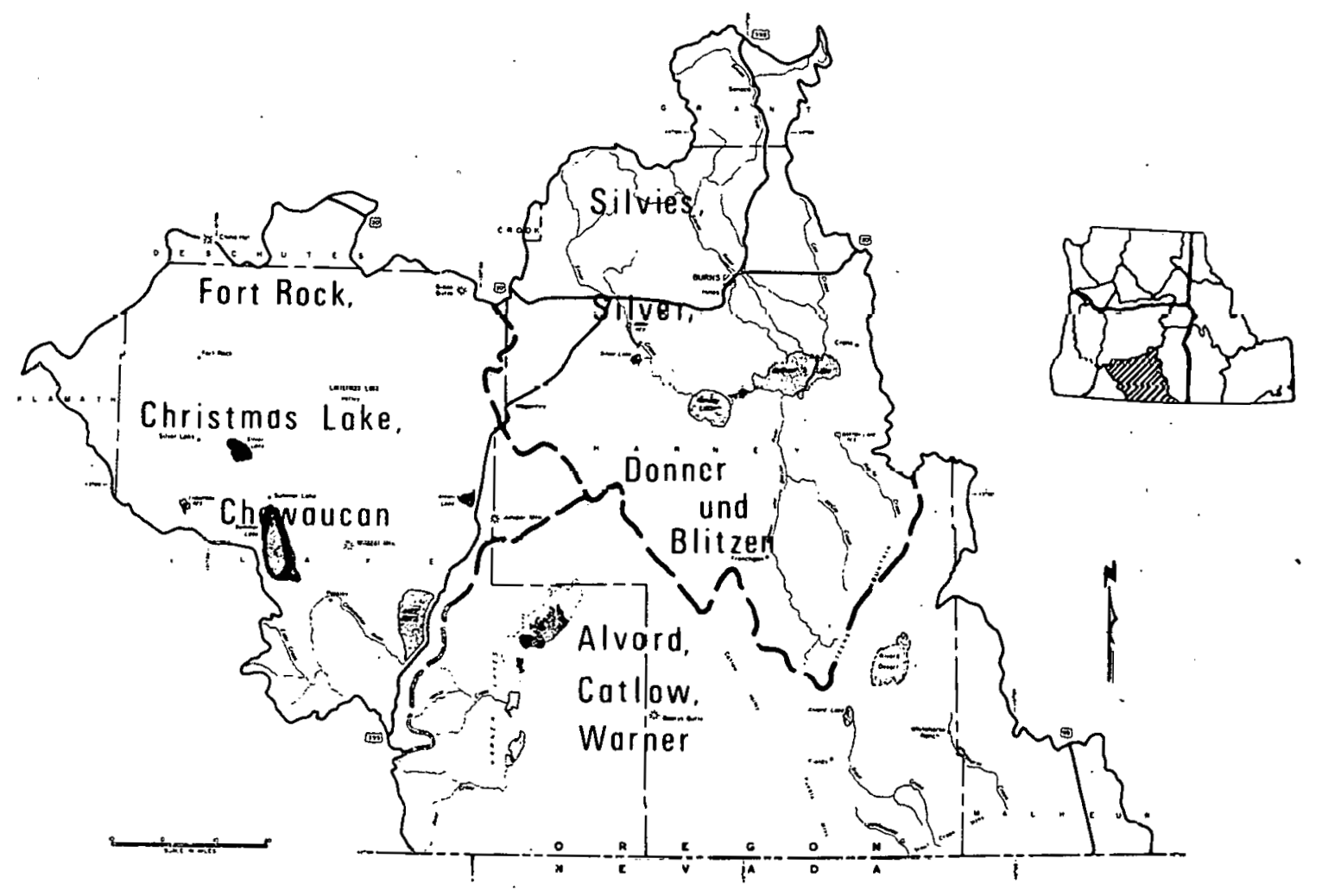

Figure 14. Map of Subregion 12 containing Fort Rock Christmas Lake - Chewaucan, Silvies - Silver Donner und Blitzen, and Alvord - Catlow Warner Subareas.

The subregion contained 262,148 irrigated acres in 1975. Of this total, 232,550 acres ( 89 percent) contained hay and pasture; limited acreages of small grain crops were also irrigated. The subregion had 723,638 acre-feet of water applied and used 44,475.8 MWH of electricity in 1975. Corresponding engineering design requirements were 896,508 acre-feet of 
water and 55,158.5 MWH of electricity. As a result of minimal water lifts, energy requirements per acre of irrigation were relatively low in this subregion.

Gravity systems covered 84 percent $(220,261$ acres) of the total irrigated acreage. The remaining percentage was partitioned among hand move, side roll and center pivot systems; hand move and side roll collectively irrigated 37,014 acres while 4,873 acres were under center pivots.

Fort Rock, Christmas Lake and Chewaucan Subarea

This subarea, located in south-central Oregon, contains five internally drained areas. Three principal streams include: Chewaucan River, draining into Lake Abert; Ana River, flowing into summer Lake; and silver creek, draining into Silver Lake. These lakes contain high alkaline water and are not suitable for irrigation; water for irrigation is instead obtained from stream flow and groundwater resources. Extensive groundwater exists in the Fort Rock-Christmas Lake area.

Table 40 contains the 1975 irrigation water and energy' requirements for this location. The subarea contained 73,053 irrigated acres with 92 percent of this acreage in hay and pasture. In addition, the area irrigated a limited acreage of small grain crops.

The subarea had 205,766 acre-feet of water applied and consumed 9,759.9 MWH of electricity in 1975. Corresponding engineering design requirements were 255,077 acre-feet of water and $12,105 \mathrm{MWH}$ of electricity. Of the total irrigation water, 89.4 percent was supplied by surface sources with low 
Table 40. 1975 water requirements and energy consumption for irrigation in the Fort Rock, Christmas Lake and Chewaucan Subarea.

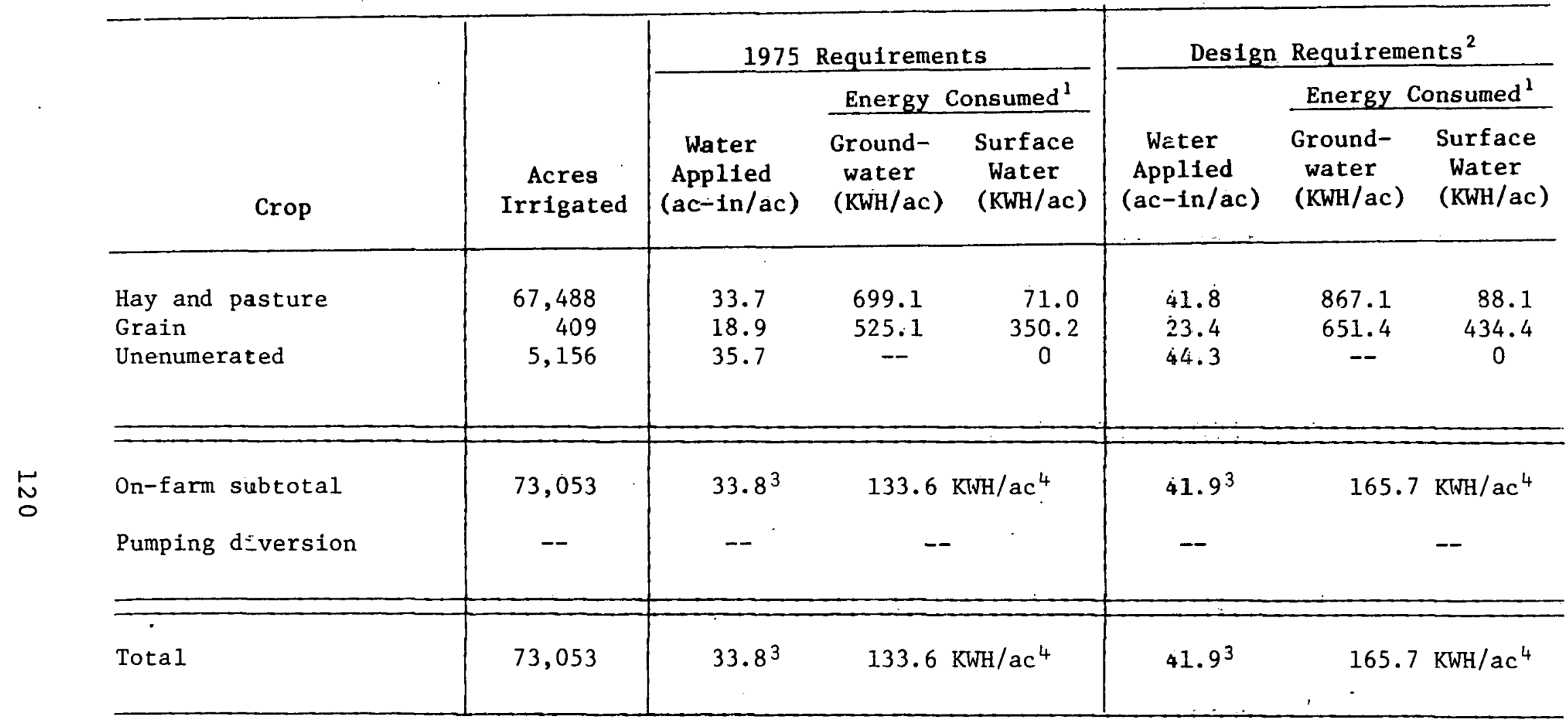

$189.4 \%$ of the water was supplied by surface sources with average on-farm pumping lifts of 10 feet and the remaining $10.6 \%$ from groundwater with average lifts of 31 feet.

2 Values represent the engizeering sizing of water and energy required to provide a crop 8 years out of 10 .

${ }^{3}$ Average water consumed for all crops in subregion.

${ }^{4}$ Average energy required for all crops and water sources in subarea. 
on-farm lifts of 10 feet. The remaining 10.6 percent of the water was pumped from groundwater with 31 feet average lifts. The small lifts associated with surface sources precipitated low total energy values for crops in this subarea.

Gravity systems irrigated 65,074 of the total 73,053 acres. The remaining acreage was irrigated by side roll and hand move on 5,615 acres plus center pivot on 2,364 acres.

\section{Silvies, Silver and Donner und Blitzen Subarea}

Three drainage systems comprise this subarea. Silvies River and Cow Creek (from the north) plus Donner und Blitzen River (from the south) drain into Malheur Lake, which overflows into Harney Lake. The third drainage system, Silver Creek, flows directly into Harney Lake. The crest of Steens Mountains on the southeast and Strawberry Range on the north comprise the major visible boundaries for this subarea.

The 1975 irrigated crops plus their water and energy requirements for Silvies, silver and Donner und Blitzen Subarea are listed in Table 41. The subarea irrigated 1I1,447 acres of hay, pasture and small grains. The area had 303,693 acre-feet of water applied and used 25,242.8 MWH of electricity in 1975. Engineering design requirements for 1975 were 376,134 acre-feet of water and $31,305 \mathrm{MWH}$ of electricity.

Of the 103,693 acre-feet of water applied in 1975, 80.9 percent was supplied by surface sources with average on-farm 
Table 41. 1975 water requirements and energy consumption. for irrigation in the Silvies, Silver and Donner, und Blitzen Subarea.

\begin{tabular}{|c|c|c|c|c|c|c|c|}
\hline \multirow[b]{3}{*}{ Crop } & \multirow[b]{3}{*}{$\begin{array}{c}\text { Acres } \\
\text { Irrigated }\end{array}$} & \multicolumn{3}{|c|}{1975 Requirements } & \multicolumn{3}{|c|}{ Design Requirements ${ }^{2}$} \\
\hline & & \multirow[b]{2}{*}{$\begin{array}{c}\text { Water } \\
\text { Applied } \\
(\mathrm{ac}-\mathrm{in} / \mathrm{ac})\end{array}$} & \multicolumn{2}{|c|}{ Energy Consumed } & \multirow[b]{2}{*}{$\begin{array}{c}\text { Water } \\
\text { Applied } \\
(a c-i n / a c)\end{array}$} & \multicolumn{2}{|c|}{ Energy Consumed ${ }^{1}$} \\
\hline & & & $\begin{array}{l}\text { Ground- } \\
\text { water } \\
(\mathrm{KWH} / \mathrm{ac})\end{array}$ & $\begin{array}{l}\text { Surface } \\
\text { Water } \\
(\mathrm{KWH} / \mathrm{ac})\end{array}$ & & $\begin{array}{l}\text { Ground- } \\
\text { water } \\
(\mathrm{KWH} / \mathrm{ac})\end{array}$ & $\begin{array}{l}\text { Surface } \\
\text { Water } \\
\text { (KWH/ac) }\end{array}$ \\
\hline $\begin{array}{l}\text { Hay and pasture } \\
\text { Grain } \\
\text { Unenumerated }\end{array}$ & $\begin{array}{r}95,214 \\
5,556 \\
10,657\end{array}$ & $\begin{array}{l}33.3 \\
16.9 \\
32.7\end{array}$ & $\begin{array}{l}733.1 \\
499.6 \\
718.4\end{array}$ & $\begin{array}{l}104.4 \\
424.9 \\
102.3\end{array}$ & $\begin{array}{l}41.3 \\
21.0 \\
4 C .5\end{array}$ & $\begin{array}{l}909.3 \\
619.6 \\
870.9\end{array}$ & $\begin{array}{l}129.5 \\
527.0 \\
126.9\end{array}$ \\
\hline $\begin{array}{l}\text { On-farm subtotal } \\
\text { Pumping diversion }\end{array}$ & $\begin{array}{c}114,447 \\
--\end{array}$ & ${ }_{--}^{32.7^{3}}$ & $\begin{array}{r}226.5 \\
-\end{array}$ & $\mathrm{KWH} / \mathrm{ac}^{4}$ & $\begin{array}{l}4 C .5^{3} \\
--\end{array}$ & $\begin{array}{r}280.9 \\
-\end{array}$ & $\mathrm{KWH} / \mathrm{ac}^{4}$ \\
\hline Total & 114,447 & $32.7^{3}$ & 226.5 & $\mathrm{KWH} / \mathrm{ac}^{4}$ & $4 C .5^{3}$ & 280.9 & $\mathrm{~K}: \mathrm{NH} / \mathrm{ac}^{4}$ \\
\hline
\end{tabular}

$180.9 \%$ of the water was supplied by surfaze sources with average on-farm pumping lifts of $10 \mathrm{feet}$ and the remaining $19.1 \%$ from groundwater with average 1 ifts of 39 feet:

${ }^{2}$ Values represent the engineering sizing of water and energy requirec to prcvide a crop 8 years out of 10 .

${ }^{3}$ Average water consumed for all srops in subregion.

${ }^{4}$ Average energy required for all crops and water sources in subarea. 
pumping lifts of 10 feet and the remaining 19.1 percent from groundwater with 39 feet average lifts. Low pumping lifts precipitated minimum energy requirements for this subarea relative to the majority of other areas. Lastly, the subarea does not contain large pump diversions.

Again, the majority $(88,151$ acres) was irrigated by gravity systems. Hand move and side roll collectively irrigated the remaining 23,296 acres.

\section{Alvord, Catlow and Warner Subarea}

The southern boundary of this closed basin is the Oregon-Nevada border; part of the northern boundary includes the Steens Mountains; Beatys Butte protrudes from the center. Most streams in the subarea are intermittent. The exceptions are: Oregon Canyon Creek, draining into Nevada; Trout Creek, flowing into Alvord Lake; Honey Creek, draining into Hart Lake; plus Twenty-mile and Deep Creeks flowing into crump Lake. The area's economy is primarily agricultural; approximately four million acres are used for rangeland livestock production.

Table 42 contains the crops, water requirements and energy consumption for irrigation in this subarea. Almost 78,000 acres were irrigated in 1975 with hay and pastures irrigating 69,848 acres. The subarea applied 214,179 acre-feet of water and consumed 9,473.0 MWH of electricity. Corresponding engineering design requirements were 265,297 acre-feet of water and $11,748 \mathrm{MWH}$ of electricity. 
Table 42. 1975 water requirements and energy consumption for irrigation in the Alvord, Catlow, and Warner Subarea.

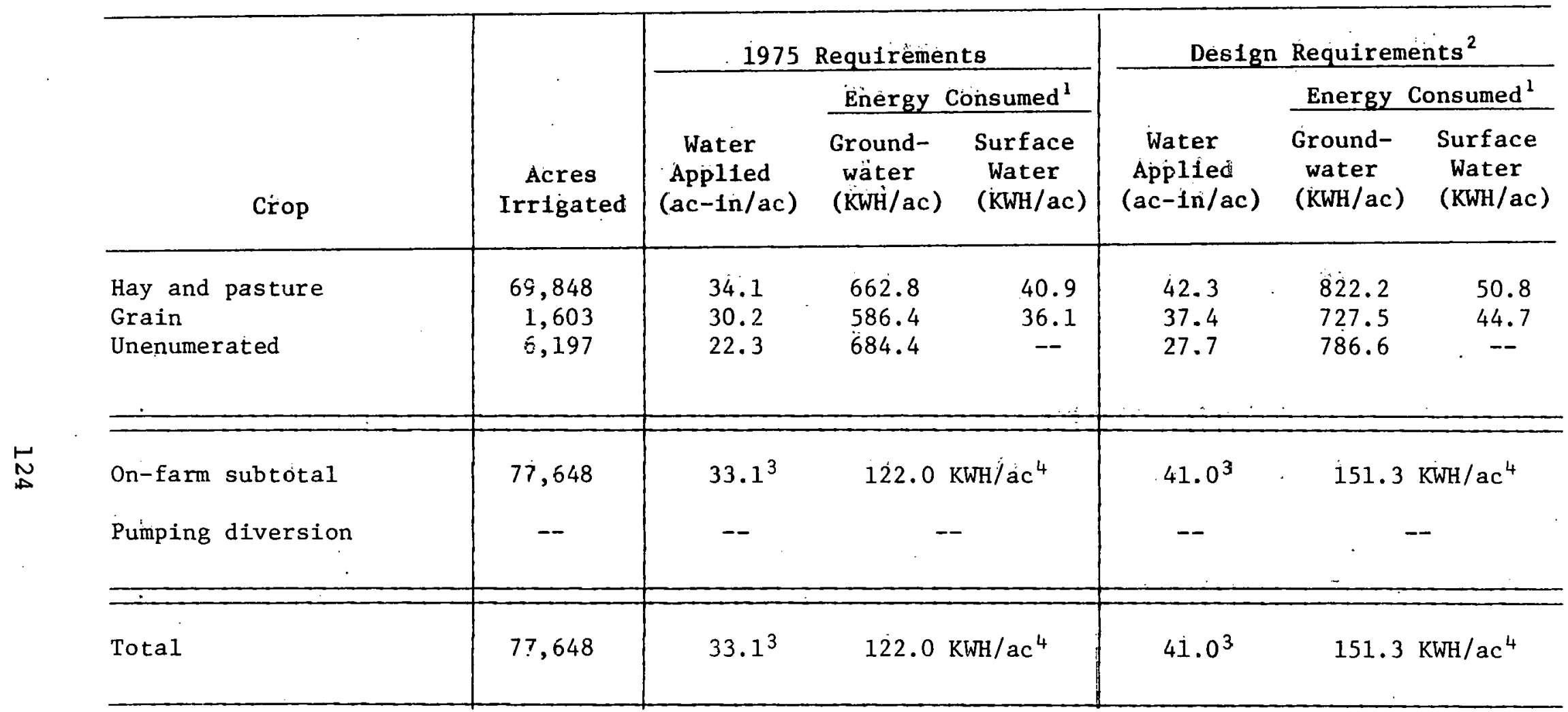

${ }^{1} 86.6 \%$ of $^{\circ}$ the water was supplied by surface sources with average on-fanm pumping lifts of 11.5 feet and the remaining $13.4 \%$ from groundwater with average lifts of 24 feet.

${ }^{2}$ Values represent the engiteering sizing of water and energy required zo provide a crop 8 years out of 10 .

${ }^{3}$ Average water consuned for all crops ir. subregion.

${ }^{4}$ Average energy required $\mathrm{fcr}$ all crops and water sources in subarea. 
Water lifts in this subarea were extremely low; 86.6 percent was supplied from surface sources with average onfarm Iifts of 11.5 feet and the remaining 13.4 percent from groundwater with 24 feet lifts.

Irrigation systems here remained consistent with the subareas throughout the subregion; gravity irrigated 67,036 acres of the total 77,648 acres in this subarea. In addition, hand move and side roll collectively irrigated 8,103 acres and center pivots covered 2,509 acres. 


\section{SUBREGION 13}

\section{Klamath}

The Klamath Drainage Basin is located in south-central Oregon and northwestern California. This study considers only the Oregon subregion, outlined by the Winter Ridge crest as its eastern boundary and the eastern slopes of the Cascade Mountains on the western edge of the subregion. Klamath includes approximately 3,600,000 acres and encompasses the major portion of Klamath County and parts of Jackson, Josephine and Lake Countics (sce Figure 15).

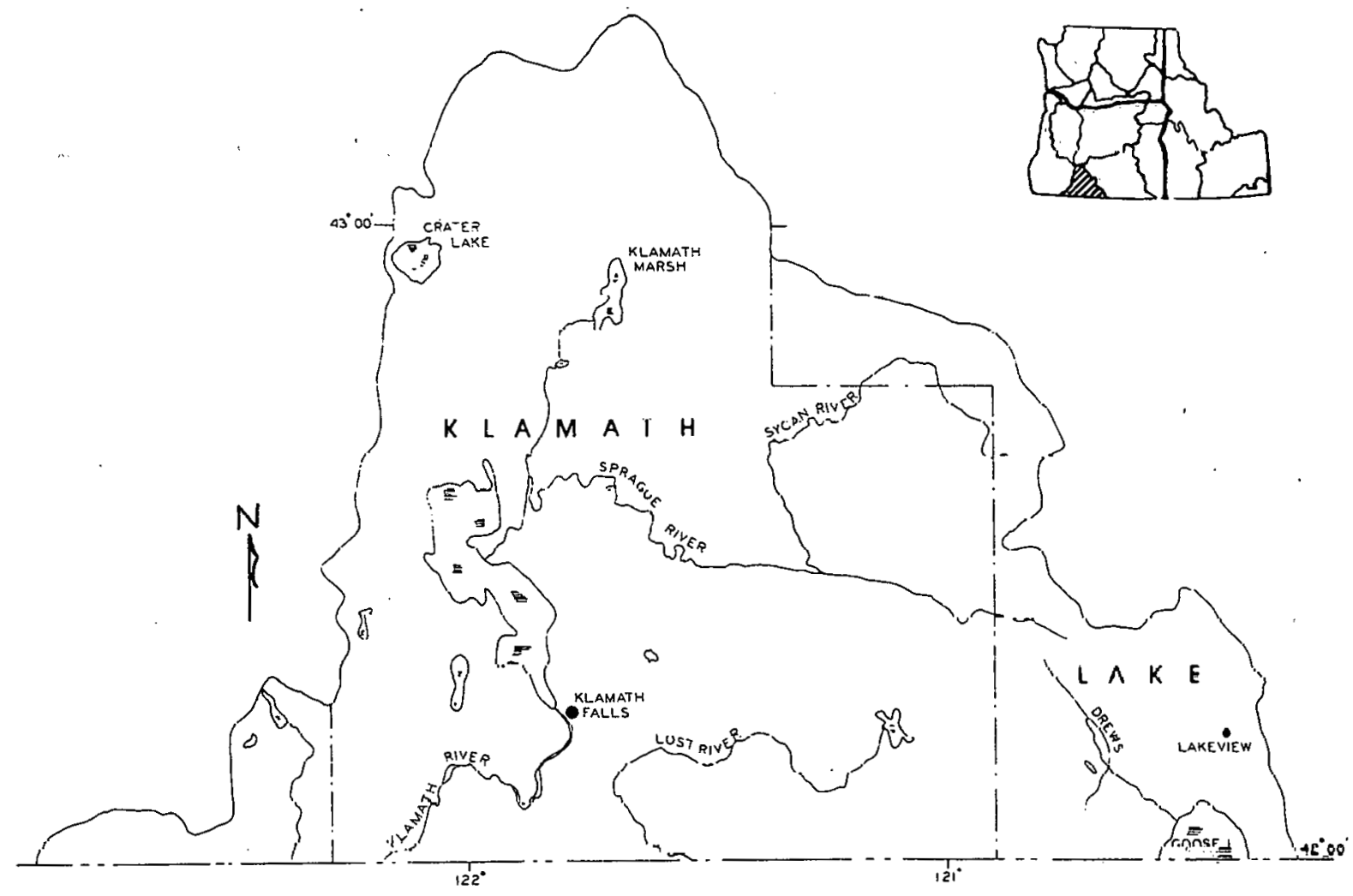

Figure 15. Map of Subregion 13 containing the Klamath Drainage Basin. 
The subregion includes a closed basin -- the Lost River drainage basin. In addition, Williamson River is situated in the northern section of the subregion and forms the major tributary to Upper Klamath Lake. Sprague River, a tributary to the Williamson River, drains the northeastern portion of the basin. Crater Lake, the only National Park within the state of Oregon, is located in this subregion. Upper Klamath Lake, the largest natural lake within Oregon, is another water feature of the basin.

The two most important contributions to the economy in the Klamath Subregion traditionally have been made by the agriculture and timber industries. Approximately 300,000 acres of privately owned land is used for agricultural production.

Table 43 lists the irrigated crops with their water and energy requirements in 1975 for Klamath Subregion. The region contained 258,612 irrigated acres with hay and pasture occupying 146,480 acres (57 percent of total). Small grains and potatoes were also irrigated.

The subregion had 838,334 acre-feet of water applied and used 85,647.5 MWH of electricity for irrigation in 1975. Corresponding engineering design requirements were 793,077 acre-feet of water and $77,070 \mathrm{MWH}$ of electricity. Of the total irrigation water, 91.2 percent was supplied from surface water sources with 10 feet on-farm average lifts; the remaining water was obtained from groundwater sources with 89 feet average lifts.

The subregion contained 117,000 acres of irrigation under Bureau of Reclamation projects. On these project lands, extensive drainage was required because of high water tables. In 
Table 43. 1975 water requirements and energy consumption for irrigation in the Klamath Subregion.

\begin{tabular}{|c|c|c|c|c|c|c|c|}
\hline \multirow[b]{3}{*}{ Crop } & \multirow[b]{3}{*}{$\begin{array}{c}\text { Acres } \\
\text { Irrigated }\end{array}$} & \multicolumn{3}{|c|}{1975 Requirements } & \multicolumn{3}{|c|}{ Lesign Requirements ${ }^{2}$} \\
\hline & & \multirow[b]{2}{*}{$\begin{array}{c}\text { Water } \\
\text { spplied } \\
(a c-i n / a c)\end{array}$} & \multicolumn{2}{|c|}{ Energy Consumed ${ }^{1}$} & \multirow[b]{2}{*}{$\begin{array}{c}\text { Wa:er } \\
\text { Applied } \\
(a c-1 r / a c)\end{array}$} & \multicolumn{2}{|c|}{ Energy Consumed ${ }^{1}$} \\
\hline & & & $\begin{array}{l}\text { Ground- } \\
\text { water } \\
(\mathrm{KWH} / \mathrm{ac})\end{array}$ & $\begin{array}{l}\text { Surface } \\
\text { Water } \\
(\mathrm{KWH} / \mathrm{ac})\end{array}$ & & $\begin{array}{l}\text { Ground- } \\
\text { water } \\
(\mathrm{KWH} / \mathrm{ac})\end{array}$ & $\begin{array}{l}\text { Surface } \\
\text { Water } \\
\text { (KWH/ac) }\end{array}$ \\
\hline $\begin{array}{l}\text { Hay and pasture } \\
\text { Grain } \\
\text { Potatoes } \\
\text { Unenumerated }\end{array}$ & $\begin{array}{r}146,480 \\
62,800 \\
8,300 \\
41,032\end{array}$ & $\begin{array}{l}43.7 \\
30.1 \\
21.2 \\
38.9\end{array}$ & $\begin{array}{r}1,409.5 \\
642.9 \\
788.2 \\
1,117.3\end{array}$ & $\begin{array}{r}207.3 \\
40.5 \\
533.0 \\
165.8\end{array}$ & $\begin{array}{l}4 J .8 \\
27.0 \\
26.3 \\
36.8\end{array}$ & $\begin{array}{r}1,157.9 \\
779.8 \\
973.3 \\
1,057.0\end{array}$ & $\begin{array}{r}170.1 \\
50.3 \\
66.3 \\
156.8\end{array}$ \\
\hline $\begin{array}{l}\text { On-farm subtotal } \\
\text { Pumping diversion }\end{array}$ & $\begin{array}{c}258,612 \\
--\end{array}$ & $\begin{array}{c}38.9^{3} \\
328,532.0\end{array}$ & $\begin{array}{r}265.1 \\
\text { ac-ft } 17,08\end{array}$ & $\begin{array}{l}\mathrm{KWH} / \mathrm{ac}^{4} \\
9.45 \mathrm{MWH}\end{array}$ & $\begin{array}{c}36.8^{3} \\
310,796.0\end{array}$ & $\begin{array}{r}235.5 \\
\text { ac-ft } 16,1\end{array}$ & $\begin{array}{l}\mathrm{KWH} / \mathrm{ac}^{4} \\
66.89 \mathrm{MWH}\end{array}$ \\
\hline Tota1 & 258,612 & $38.9^{3}$ & 331.18 & $\mathrm{KWH} / \mathrm{ac}^{4}$ & $36.8^{3}$ & 298.0 & $1 \mathrm{KWH} / \mathrm{ac}^{4}$ \\
\hline
\end{tabular}

$191.2 \%$ of the water was supplied by surface sources with average on-farm pumping lifts of 10 feet and the remaining $8.8 \%$ from groundwater with average lifts of 89 feet.

${ }^{2}$ Values represent the engineering sizing. of water and energy required to provide a crop 8 years out of 10.

${ }^{3}$ Average water consumed for all crops in subregion.

${ }^{4}$ Average energy required for ail crops and water sources in subregion. 
areas outside Bureau projects, water availability was dependent upon runoff from mountains in which runoff volumes varied widely from one year to the next.

Gravity systems irrigated 203,914 acres (79.percent) of the total 258,612 acres. Hand move and side roll collectively irrigated 44,608 acres. Remaining systems and their acreages were: 6,225 acres of solid set, 3,230 acres of center pivot, and 635 acres of big gun. 


\section{SUBREGION 14}

Bear River

The Bear River Subregion is situated in the southeastern corner of Idaho and is shown in Figure 16. Although this study's area includes only that portion of the Bear River Basin in Idaho, the entire basin includes portions of Utah, Idaho and Wyoming. Thirty-six percent of the total area is in Idaho.

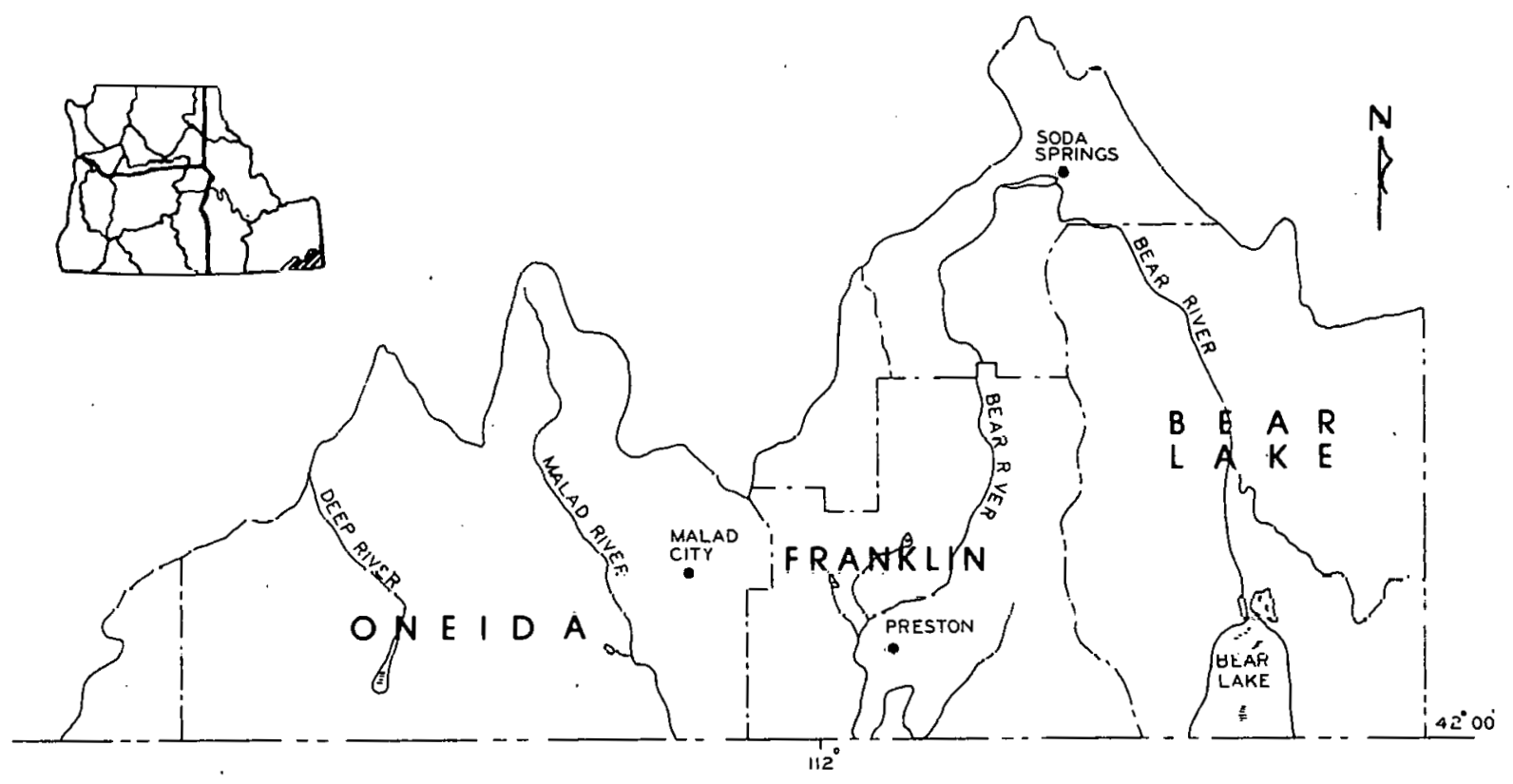

Figure 16. Map of Subregion 14 containing Bear River Basin.

Elevations in the subregion range from 4,440 feet in the valiey to 9,953 feet at Meade Peak east of Georgetown, Idaho. About one-half of the subregion is mountainous and lies above 6,000 feet. Major valleys and mountain ranges 
trend north-south. Tributary valleys intersect at right. angles. Tributary stream gradients are steep, whereas main valley gradients are comparatively gentle.

Annual precipitation within the subregion ranges from 14 to about 50 inches, with agricultural areas receiving approximately 14 inches. Agriculture is a major economic activity, accounting for one-third of the area's employment.

Table 44 presents the 1975 water and energy in Bear River Subregion. The subregion irrigated 236,580 acres. Again, hay and pasture were the predominant crops with 163,683 acres. Additional irrigated crops included small grains, vegetables, fruits, nuts, berries, field corn, legume seed, potatoes and sugar beets.

The 236,580 acres had 514,561 acre-feet of water applied and used 78,639.2 MWH of electricity. Engineering design requirements were 577,649 acre-feet of water and 87,913.1 MWH of electricity. Surface sources, with average on-farm pumping lifts of 10 feet, supplied 78.1 percent of the water. The remaining 21.9 percent was obtained from groundwater with average pumping lifts of 250 feet.

Hand move, gravity and side roll irrigation systems dominated the region, with respective acreages of 107,521 , 85,105 , and 39,411 acres. Center pivot and solid set systems irrigated 3,029 and 1,514 acres, respectively. 
Table 44. 197.5 water requirements and energy consumption for irrigation in the Bear River Subregion.

\begin{tabular}{|c|c|c|c|c|c|c|c|}
\hline \multirow[b]{3}{*}{ Srop } & \multirow[b]{3}{*}{$\begin{array}{c}\text { Acres } \\
\text { Irrigated }\end{array}$} & \multicolumn{3}{|c|}{1975 Requirements } & \multicolumn{3}{|c|}{ Design Requirements ${ }^{2}$} \\
\hline & & \multirow[b]{2}{*}{$\begin{array}{c}\text { Water } \\
\text { Applied } \\
(\text { ac-in/.ac })\end{array}$} & \multicolumn{2}{|c|}{ Energy Consumed ${ }^{l}$} & \multirow[b]{2}{*}{$\begin{array}{c}\text { Water } \\
\text { Applied } \\
(\mathrm{ac}-\mathrm{in} / \mathrm{ac})\end{array}$} & \multicolumn{2}{|c|}{ Energy Consumed ${ }^{1}$} \\
\hline & & & $\begin{array}{l}\text { Ground- } \\
\text { water } \\
\text { (KWH/ac) }\end{array}$ & $\begin{array}{l}\text { Surface } \\
\text { Water } \\
(\mathrm{KWH} / \mathrm{ac})\end{array}$ & & $\begin{array}{l}\text { Ground- } \\
\text { water } \\
(\mathrm{KWH} / \mathrm{ac} \text { ) }\end{array}$ & $\begin{array}{l}\text { Surface } \\
\text { Water. } \\
\text { (KWH/ac) }\end{array}$ \\
\hline $\begin{array}{l}\text { Hay and pasture } \\
\text { Grain } \\
\text { Vegetables } \\
\text { Fruits, nuts and berries } \\
\text { Field corn } \\
\text { Legume seed } \\
\text { Potatoes } \\
\text { Sugar beets, sugar }\end{array}$ & $\begin{array}{r}163,683 \\
55,085 \\
2,140 \\
19 \\
6,489 \\
2,572 \\
3,810 \\
2,782\end{array}$ & $\begin{array}{l}26.9 \\
23.8 \\
18.0 \\
38.2 \\
24.7 \\
36.7 \\
19.1 \\
30.0\end{array}$ & $\begin{array}{c}1,263.0 \\
1,157.7 \\
-- \\
-- \\
-- \\
-- \\
1,007.8 \\
1,442.1\end{array}$ & $\begin{array}{r}82.7 \\
86.3 \\
0.0 \\
0.0 \\
0.0 \\
0.0 \\
102.9 \\
105.5\end{array}$ & $\begin{array}{l}30.4 \\
25.8 \\
22.4 \\
42.7 \\
31.6 \\
42.0 \\
21.2 \\
34.8\end{array}$ & $\begin{array}{c}1,427.5 \\
1,254.9 \\
-- \\
-- \\
-- \\
-- \\
1,118.6 \\
1,672.9\end{array}$ & $\begin{array}{r}93.0 \\
93.5 \\
0.0 \\
0.0 \\
0.0 \\
0.0 \\
114.2 \\
117.0\end{array}$ \\
\hline On-farm stbtotal & 236,580 & $26.1^{3}$ & 3.32 .4 & $\mathrm{KWH} / \mathrm{ac}^{4}$ & $29.3^{3}$ & 371.6 & $\mathrm{KWH} / \mathrm{ac}^{4}$ \\
\hline Pumping diversion & -- & -- & - & & -- & - & - \\
\hline Total & 236,580 & $26.1^{3}$ & 332.4 & $\mathrm{KWH} / \mathrm{ac}^{4}$ & $27.3^{3}$ & 371.6 & $\mathrm{KWH} / \mathrm{ac}^{4}$ \\
\hline
\end{tabular}

$178.1 \%$ of the water was supplied by suriace sources with average on-farm puming lifts of 10 feet and the remaining $21.9 \%$ from groundwater with average lifts of 250 feat.

${ }^{2}$ Values represent the engineering sizing of water and energy required to proride a crop 8 years out of 10 .

${ }^{3}$ Average water consumed for all crops in subregion.

${ }^{4}$ Average energy required for all crops and water sources in subregion. 


\section{REGIONAL AND STATE SUMMARY}

Table 45 contains a summary of the water requirements and energy consumption for irrigation in each subarea. Subregional water applications ranged from 1.3 to 5.5 acre-feet per acre of water, with an average regional value of 3.1 acre-feet per acre. Per-acre energy consumption varied even more dramatically, from 169.7 to 2,663.1 $\mathrm{KWH} /$ acre. Regional average energy consumption was $798.7 \mathrm{kWH} /$ acre. Regional engineering design requirements were 3.3 acre-feet of water and $821.4 \mathrm{KWH}$ per acre of irrigated land. The region totaled the following acreages for each major irrigation system: gravity, 4,063,948 acres; hand move, 1,428,341 acres; side roll, 1,068,059 acres; center pivot, 476,498 acres; solid set, 117,035 acres; permanent, 89,741 acres; big gun, 43,976 acres; and drip, 3,170 acres.

Oregon irrigated 1,850,660 acres in 1975. This land area had 5,001,001.5 acre-feet of water applied and consumed 932,050.4 MWH of electricity, yielding 2.7 acre-feet of water and $503.6 \mathrm{KWH}$ of energy per acre. Irrigation systems employed, with their respective acreages, were: 952,684 acres of gravity; 422,145 acres of hand move; 321,436 acres of side roll; 97,291 acres of center pivot; 29,367 acres of big gun; 15,440 acres of solid set; 12,025 acres of permanent; and 272 acres of drip.

A total of $1,594,457$ acres was irrigated in washington in 1975; of the three states, Washington had the highest levels of water and energy usage. Approximately 4.3 acre-feet of water were applied and 1,782.2 $\mathrm{KWH}$ of electricity were consumed by an "average" acre in Washington. Irrigation systems and acreages were: as follows: gravity, 654,292 acres; side roll, 415,445 acres; hand move, 200,477 acres; center pivot, 200,140 acres; permanent, 77,158 acres; solid set, 30,932 acres; big gun, 13,115 acres; and drip, 2,898 acres. 
Table 45. 1975 water requirements and energy consunption for irriga:ion in each subregion and state in the reglon.

\begin{tabular}{|c|c|c|c|c|c|c|c|c|c|}
\hline \multirow[b]{2}{*}{ Subregion } & \multirow[b]{2}{*}{$\begin{array}{c}\text { Acres } \\
\text { ixrigated }\end{array}$} & \multicolumn{4}{|c|}{1975 Requirements } & \multicolumn{4}{|c|}{ Lesign Requirements } \\
\hline & & $\begin{array}{l}\text { Water } \\
\text { applied } \\
\text { (ac- } f t)\end{array}$ & $\begin{array}{l}\text { Energy } \\
\text { consumed } \\
\text { (MWH) }\end{array}$ & $\begin{array}{c}\text { Water/ac } \\
(a c-f t / a c)\end{array}$ & $\begin{array}{l}\text { Energy/ac } \\
(\mathrm{KWH} / \mathrm{ac})\end{array}$ & $\begin{array}{l}\text { Water } \\
\text { applied } \\
\text { (ac-ft) }\end{array}$ & $\begin{array}{l}\text { Enercy } \\
\text { consur.ed } \\
\text { (MWE:) }\end{array}$ & $\begin{array}{c}\text { water/ac } \\
(a c-f t / a c)\end{array}$ & $\begin{array}{l}\text { Energy/ac } \\
\text { (KWH/ac) }\end{array}$ \\
\hline 1 & 52.850 & 111,876 & $58,139.2$ & 2.1 & $1,100.1$ & 120,376 & 63,009 & 2.3 & $1,192.2$ \\
\hline 2 & 767,400 & $3,143,717$ & $2,075,173$ & s.t & $2,633.1$ & $3,082,944$ & $1,987, \leq 88$ & 4.0 & $2,589.9$ \\
\hline 3 & 526.000 & $2,893,000$ & $323,437.4$ & 5.5 & 614.9 & $2,621,233$ & 294.891 .6 & 5.0 & 560.6 \\
\hline 4 & $2,542,700$ & $5,839,114$ & $1,490,771.4$ & 2.7 & 586.3 & $7,666,844$ & $1,660, \approx 49.3$ & 3.0 & 652.9 \\
\hline 5 & $1,319,928$ & $7,443,773$ & $500,093.4$ & $\Xi .4$ & 378.9 & $4,993,265$ & $560, \varepsilon 55.4$ & 3.8 & 424.9 \\
\hline 6 & 267,270 & 674,998 & 125,266 & 2.5 & $46 \dot{\mathrm{B}} .7$ & 765,779 & $140, \equiv 77.8$ & 2.9 & 525.2 \\
\hline 7 & 575,574 & $1,763,840$ & 774,270 & $\Xi .1$ & $1,345.2$ & $1,731,544$ & $746, \leq 34.8$ & 3.0 & $1,296.9$ \\
\hline 8 & 13,039 & 23,362 & 9,007 & 1.8 & 690.8 & 27,056 & $10, \dot{4} 49$ & 2.1 & 801.4 \\
\hline 9 & 262,148 & 345,050 & $131,899 . i$ & 11.3 & 503.3 & 419,301 & $160,277.7$ & 1.6 & 611.6 \\
\hline 10 & 114,472 & 273,413 & $56,693.7$ & 2.4 & 495.3 & 307,259 & $64, \dot{\varepsilon} 59.3$ & 2.7 & 566.6 \\
\hline 11 & 92,132 & 185,799 & 69,559 & $z .0$ & 755.0 & 212,671 & 79,307 & 2.3 & 860.8 \\
\hline 12 & $\begin{array}{c}262,148 \\
\vdots\end{array}$ & 723,638 & 44.475 .8 & 2.8 & 169.7 & 896,508 & $55,156.5$ & $3 . \dot{4}$ & 210.4 \\
\hline 13 & 258,612 & 838,334 & $85,647.5$ & 3.2 & 331.2 & 793.077 & 77,670 & 3.1 & 298.0 \\
\hline 14 & 236,580 & $5: 4,561$ & $78,639.2$ & 2.2 & 332.4 & 577,549 & $87,913.1$ & 2.4 & 371.6 \\
\hline OREGON & $1,850,660$ & $5,001,001.5$ & $932,050.4$ & 2.7 & 503.6 & $5,467,772,4$ & $913, \subseteq 92.9$ & 3.0 & 493.9 \\
\hline WASHINGGTON & $1,594,457$ & $6,8: 2,246.5$ & $2,841,572.2$ & 4.3 & $1,782.2$ & $6,530,592.3$ & $2,743,509.9$ & 4.1 & $1,720.7$ \\
\hline IDAHO & $3,845,651$ & $10,951,227.0$ & $2,049,448,8$ & 2.8 & 532.9 & $12,217,040.5$ & $2,330,737,6$ & 3.2 & 606.1 \\
\hline TOTAL & $7,290,768$ & $22,774,475$ & $5,823,071.7$ & 3.1 & 798.7 & $24,215,406$ & $5,988,340,5$ & 3.3 & 821,4 \\
\hline
\end{tabular}


Idaho irrigated $3,845,651$ acres, requiring 10,951,227.0 acre-feet of water to be applied and 2,049,448.8 MWH of electricity to be consumed. The average acre had 2.8 acre-feet of water applied and consumed $532.9 \mathrm{KWH}$ of electricity. A partitioning of Idaho's irrigation systems was as follows: 2,456,972 acres of gravity; 805,719 acres of hand move; 331,178 acres of side roll; 179,067 acres of center pivot; 70,663 acres of solid set; 1,494 acres of big gun; and 558 acres of permanent. 


\section{REFERENCES}

Barnes, K. K. et al. 1973. Energy in Agriculture. A Task Force of. the Council for Agricultural Science and Technology.

Bartholemew, W. S. and R. Debow. 1970. Ground Water Levels 1967-1968. Ground Water Report No. 15. State Engineer, State of Oregon, Salem.

Ducret, G. L. and D. B. Anderson. 1965. Records of Wells, Water Levels and Chemical Quality of Water in Baker Valley, Baker County, Oregon. Ground Water Report No. 6. State Engineer, State of Oregon, Salem.

Frank, J. F. and N. A. Johnson. 1970. Selected Ground Water Data in the Eugene-Springfield Area, Southern Willamette Valley, oregon. Ground water Report No. 14. State Engineer, State of Oregon, Salem.

Frank, J. F. and N. A. Johnson. 1975. Ground Water Data in the Harrisburg-Halsey Area, Central Willamette Valley, Oregon. Ground Water Report No. 22. State Engineer, State of Oregon, Salem.

Hampton, E. R. 1963. Records of Wells, Water Levels and Chemical Quality of Ground Water in the Molalla-Salem Slope Area, Northern Willamette Valley, Oregon. Ground Water Report No. 2. State Engineer, State of Oregon, Salem.

Helill, D. C. 1968, Records of Well.s, Water Levels and Chemical Quality of Water in the Lower Santiam River Basin, Middle Willamette Valley, Oregon. Ground water Report No. 13. State Engineer, state of Oregon, Salem. 
Hirst, E. 1974. Food Related Energy Requirements. Science $184: 134-138$.

Jensen, M. C. , S. T. Iin, A. J. Anderson, C. W. Ek, G. N. Sundstrom, and J.W. Trull. 1969. Irrigation Water Requirements Estimates for Washington. Washington Agricultural Experiment Station Circular 512. Washington State University, Pullman.

Leonard, A. R. 19\%. Ground Water Resuluces in Harney Valley, Harncy County, oregon. Ground Water Report No. 16. water Resources Department, Salem, Oregon.

Leonard, A. R. and A. B. Harris. 1974. Ground water in Selected Areas in the Klamath Basin, Oregon. Ground Water Report No. 21. State Engineer, State of Oregon, Salem.

McCall, W. B. 1975. Ground Water Conditions and Declining Water Levels in the Ordnance, Morrow and Umatilla Counties, Oregon. Ground Water Report No. 23. Water Resources Department, Salem, oregon.

Price, D. 1961. Records of Ground Water in the French PrairieMission Bottom Area, Northern Willamette Valley, Oregon. Ground Water Report No. 1. State Engineer, State of oregon, Salem.

Price, D. and N. A. Johnson. 1965. Selected Ground Water Data in the Eola-Amity Hill Area, Northern Willamette Valley, Oregon. Ground Water Report No. 7. State Engineer, state of Oreyur, Salem.

Sceva, J. E. 1966. A Reconnaissance of the Ground Water Resources of the Hood River Valley and the Cascade Locks Area, Hood River County, Oregon. Ground Water Repurt No. 10. Water Resources Department, Salem, Oregon. 
Sutter, R. J. and G. L. Corey. 1970. Consumptive Irrigation Requirements for Crops in Idaho. Idaho Agricultural Experiment Station Bulletin 516. University of Idaho, Moscow.

United States Department of Agriculture, Soil Conservation Service, Engineering Division. 1970. Irrigation Water Requirements. Technical Release No. 21 (Rev, 2), 88 pp.

United States Geological Survey. 1972. Annual Summary of Water Quality Data for Selected Sites in the Pacific Northwest. Prepared by the Northwest Water Resources Data Center, Portland, oregon.

•

Watts, D. G., C. R. Dehlinger, J. W. Wolfe, and M. N. Shearer. 1968. Consumptive Use and Net Irrigation Requirements for Oregon. Oregon Agricultural Experiment Station Circular 628. Oregon State University, Corvallis.

Williams, D. W. and W. J. Chancellor. 1974. Simulation of Crop Response to Energy Inputs. ASAE Paper No. 74-5019.

\section{Maps and Regional Descriptive Data from:}

Pacific Northwest River Basins Commission. 1971. ColumbiaNorth Pacific Region Comprehensive Framework Study. Main Report and Appendices IX, XVI. 
DiSTRIfUTION!

:o. of

Copies

OFFSITE

A. A. Churri .

FRDA Clicago Watent Group

9800 South Cass fivenue

Argonrie, IL 60439

D. S. Ballantine

[ROA Divison of Riomedical and [nvironnisllal Research

Washington, DC 20545

R. P. Blaunstein

ERDA Divison of Bionedical and Enviromiantal. Research

Washington, OC 20545

H. W. Burr

ERDA Division of Bionedical and Envircinnental Pescarch

Washington, DC 20545

R. L. Butenhoff

ERDi Divison of Biomedical and Environmental Research

Hashington, DC 20545

C. E. Carter

ERDA Division of Bionedica] and Environinental Research Washirigtcil, OC 20545

C. W. Eơington

ERDA Division of Biomedical and Envirormental Research Washington, DC 20545

W. 0 . Forster

ERCA Division of Bioncdical and Envirommantal P.esearch

Nashington, DC 20545

G. J. Rotariu

ERDA Division of Bionedical and Environmenta? Research Washington, DC 20545

\section{H. Slade}

[RDA Divison of Biomedica] and Envirommental Research Washington, DC 20545

j. Swincbroad

FRDA Division of Biomedical and Envoronmental Researcli Haslington, OC 20545

H. H. Neyzen

EROA Division of Biomedical and Environmental Research

Washington, DC 20545
No. of

Ho. of

Copies

R. H. Hood

EROA Division of Biomedical and Environtriental Pesearch

Hashingtion, DC. 20\$45

H. F. liott

ERDA Division of Environmental Control Tecinology

Wastiington, DC 20545

M. Reilly

ERDA Division of Fossil Energy

Washington, DC 20545

H. L. Hollister

Deputy Assistant fidministrator for Environilient and Safety

Washington, DC 20545

J. L. Liverman

ERDA Assistant Administrator for Environment and Safety Washington, DC 20545

J. Coleman

ERDA Office of Environmental Policy Analys is

Washington, OC 2.0545

B. W. Wachholz.

ERDA Office of Environnental

Policy Analysis

Washington, DC 20545

E. S. Burton

ERDA Office of Planning. Analys is and Evaluation Washingtor, DC 20545

N. F. Barr

ERDA Division of Technology Overview

Washington, DC 20545

W. G. Beiter

ERDA Division of Technolcgy Overview

Washington, DC 20545

R. D. Cooper

H.RIDA Livision of Technology Overview

Hashington, DC 20545

P. H. Gearhart

ERDA Division of Technology Overview

Washington, UC 20545

R. R. Newiton

ERDA Division of Terhnology Overvicu

Washington, DC 205.45
Cupies.

H. R. Hassen

ERDA Division of Technology Overvicy

Hashington, oc 20545

A. B. Joseph

office of liuclear Regulatory Research

U.S. Nuclear Pegulatory Commission

Washington, DC 20555

F. G. Lowman

Office of Nuclear Regulatory Research

U.S. Huclear Regulatory Commission

Washington, DC 20555

E. E. Held

Office of Standards Development

U.S. Nuclear Regulatory Commission

Washington, DC 20555

27

ERDA Technical Information Center

J. B. Robeitison

Federal Energy Administration

Room 1992

Federal Building

915 Second Avenue

Seattle, WA $9 \$ 174$

L. E. Coate

U.S. Enviromental Protection Agency, Region $X$

Seattle, IIA 98101

E. Croke

Argonne liational Laboratury

9700 South Cass Avenue

Argonne, IL. 60439

L. J. Hoover

Argonne Hational Laboratory

9700 South Cáss Nvenuc

Argonne, IL 60439

P. M. Mcier

Bldg. 475

Bronkluaven liational Laboratory Upton, NY 11973

P. Palmedo

Bldq. 475

Grookhaven National Laboratory Upton, NY 11373

H. Siri

University of California - LBL

Lawrence Lerkeley Latoratory

Berkieley, CA 94720 
lio. of

Copies

D. Layton

Univelesty of California.

LLL

Lawrence Livel bore Laboratory

F.o. box 80s

Livermole, Cfi 94550

E. Hamii i

Los Mantos Scientific

Laboratory

P.0. Box: 1603

L (:) Alomos, fill 87595

R. K. lohrding

Los Alanus Scientific

Laboratory

University (If Califormia

P.O. Bกx 156.3

l.os Alanos, Nin 875.45

R. H. Davis

Oak Ridge liational

I.aboratory

P.0. Box $X$

Oak Ridge, TN 37830

H. Fulkerson

Oak Ridge l!ational Laboratory

P.0. Box $X$

Oak Ridge, TN 37830

Col. G. R. Robertson

District Engincer

Alaska District

Corps of Engincers

Anchorage, AK yyblU

R. Estess

State Clearinghouse

Division of Policy

Development and Planning

office of the Governor

Pouch AD

Juneau, AK 99801

J. Lowell Jensen

Public lltililies

Commissinn

1100 Hacliay Building

338 Denall street

Anchorage, AK 99501

W. C. McConkey, Director

Division of Encrgy and Power Development

Department of Comnerce and Economic Developinent

Mackay Building

338 Denali Strect.

Anchorage, AK 99501 1io. of

Copices

G. Hurtin

Departme!ni of Ratural

liesullices

11 th Floor, State

office Blifg.

Fouch $M$

Juneau, dk: 99311

H. F. Thomis

Regional Eugineer

Bureau of Poiver

555 Battery Street

Room 175

San Francisco, CA 94111

D. Guss

Burcau of State Planning and Community Arrairs

Slale Hulsi

Boise, I0 83720

K. D. Smith

Public Utilities

Comnission

472 W. Washington St.

Boise, II) 83720

R. J. Vissia

Regional Director

Pacific llorthisest Region

(Columbia River Basin)

Federal Euilding,

U.S. Courl House

$550 \mathrm{~W}$. Fort Strcet

Boise, ID 83724

R. N. Wisp

Bureau of State Planning and Community Attairs

State House

Boise, 1083720

R. Hulme

State Clearinghouse

office of Budget and

Program Planning

232 Capitol Building

llelena, NiT 59601

ii. 0. Mur leisen

Energy Advisory Council

c/o Lt. Goverrior's Uttice

Capitol Building

Helena, IIT 59601

J. Nybo

Energy Advisory Council

c/o Lt. Governor's Uffice

Capitol Building

Helena, HT 59601

W. Opitz

Public Service Commission

1227 11 th Avenue

Helena, HT 59601
No. of

Copies

B. Roberts

State lnand Use

Planning Burean

Departrisat of Coil anity

Affairs.

Capitol lost office

Helend, HiT 5ogol

A. C. Tsao

Eneray Pranning Division

Depat tment of Raturat

Resources and Conservation

32 South Ewing

Helena, MT 59601

H. Elauner

Conscryation and Development Commission

1175 Court Strcet, N..E.

Salem, OR 97301

Charles Davis

Public Utility Connissioner

Lobor and Inclustries BIdg.

Saleill, OR 97310

Col. H. L. Arnold, J.r.

District Engineer

Portlard District

Corps of Engineers

2850 S.E. 82nd Ave.

(97260)

P.0. Box 2946

Portland, $O R \quad 972.08$

Maj. Gen. H. E. Peel

Division Engineer

North Pacific Division

Coips of Enyilieers

210 Custom House

Portland, OR 97209

Dr. F. D. Miller

Oregon Department of Energy

528 Cottage, N.E.

Salem, OR 97310

Dr. K. Woods

[nergy Facility siting

Division

Departiment of Energy

528 Cullaye, N.E.

Salem, OR 97310

W. Young

Intergoverninental Relations Division

Orfice of Llee Guvernur 210 Cottage Strcet, S.E.

Salem, OR 97310 
lin. of

Cujics

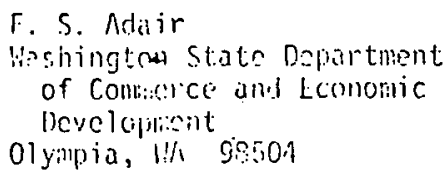

Co. C. J. Niloire

Listrict Enginnor

l'alla lialla District

Coips of Enginesers

Blog. 60?, City-County Airport

Halla Halla, wn 9936 ?

Col. J. A. Potcot, Jr.

District Enginser

Seattle District

Corps of Engineors

1519 Mlastian bay Souch

Scattle, in 98134

R. Lel:is

Assistant Director

office of Progran Planning and Fiscal lianagenent

State Plaming Division

House Office Builuing

01 ympia, HA 93504

R. Polzin

Energy Facilities Site

Evaluation Council

820 East Fifth Avenue

Olympia, IAA 98504

E. T. Shaw

Utilities and Transportation Commissian

Highwa's-Licenses Building

Olympia, Wh 98504

L. K. Hall, Directior

Idaho Ene:rgy Office

State House

Boise, ID 83770

L. Bradley

Washingtor State Energy office

1000 Cherry

Olyınia, HA 98504

M. Walsli

Departinent of Ecology

State of Hashington

Olyinpia, WA 98504

A. J. Eliopulos

Public Service Commission

Supreme Court Building

Cheyenne, WY 82002

D. B. Freudenthal

State Plamning Coordinator's ofrice

office of the Governor

State Capitol

Cheyenne, HY 82002 lin. of

- Copics

D. Hoffirian

Mineral Development nivision

Deportrent of [cono. :

flanning and Developent.

720 best loth strot

cheyenne, in $820 \%$ ?

F. C. Binod

Bonneville Power

Administration

P.0. Eo\% 36?.

Portland, OR 97 ros

R. S. Gens

Bomeville Power

Administration

P.0. Box 3621

Portland, OR. 97202

J. Hoozen

Bonneville Fon:r

Administrotion

P.0. Bo\% 3621

Portland, $0 R \quad 97208$

J. C. Loosli

Bonneville Power

Administration

P.0. Box 3621

Portland, OR 97208

C. H. Hoore

Bonneville Power Rdministration

P.0. Box 3621

Portland, OR 97208

M. Katz

Northwest Energy Policy Project

1096 Lloyd Building

700 N.E. Miul tno!nah Street

Portland, OR 97232

R. Lewis

Northwest Energy Policy.

Project

1096 Lloyd Building

700 N.E. Multnoniah Street

Portland, OR 97232

W. E. Bruner

Pacific Northwest Regional Commission

1205 Vashington

vallcuuvei, wh gocco

D. J. Lane

Pacific Northwest River Basins Commission

1 Columbia River

P.0. Box 208

Vancouver, WA 98660
No. ni

ropires

Or. 0. Osborne

Orcoon State University

Elecirical Engincering Departiinent

Corvallis, On 97331

Dr. R. Helisin!

Oregon state University

Agricultural Engincering

Department

Corvallis, OR 97331

Dr. J. Jaksch

Corvall is Environmental Research Laboratory

Corvallis Environtierital

Protection Agency

Corvallis, OR 9733\}

J. Brar

Washington State University

Pullman, Wit 99163

G. Hinman

Washington State University

Pulliran, HA 99163

R. T. Miller

Vice President

Enginecring and Gas Control

Northiest ilatural Gas Co.

123 H.U. Flanders Street

Portland, OP 97209

H. S. Johnson

Portland General Electric Co.

621 S.W. Alder strect

Portland, OR 97205

G. A. Perrault

Portland General Electric Co.

621 S.W. Alder Street

Portland, OR 97205

C. L. Sauvie

Portland General Electric Co.

62l S.14. Alder Street

Portland, OR 97205

J. L. Hilliams

Portland General Elsctric Co.

621 S.H. NIder street

Portliand, OR 97205

R. A. Duncan

Coordination Engineer

Northi:est Yower Pool

920 S.H. 6th Ave., Rm. 1210

Portland, on 97204 
1!u. of

Cogies

H. Konsista

lidshington fab? ic Fourr

Supply Systoil

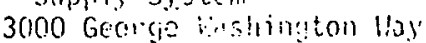

Richland, li: $993 \% 2$

D. Renberger/b. F. Bailey

llachingtor fublic Pourey

Supply Sysitial

3000 Cenren listington liay

Richland, Wi 99352

R. Tilison

Hashinglen Pubtic puser

Suppiy System

3000 George Vishington Way

Richland, $1 ! 1999352$

R. Hocdruff

Washinglen Public Power

Supply System

3000 Crecige boshington hay

Richland, $1: A 99352$

D. N. Horris

The Rand Corporation

1700 Hill Street

Santa línica, CA 90406

J. W. Ellis

Puget Sound Power and Light Conipany

Puget Power Building

Beilevue, I:A 98009

L. E. $\mathrm{Ha} 1 \mathrm{I}$

Puget Sound Power and Light. Cuinually

Puget Power Bujlding

Bellevue, in 98009

B. C. Thomas

Puget Sound Power and Light Company

Puget Power Building

Beilevue, :I:A 98009

T. E. Browne

Electric Power Resenrch Institute

3412 Hilluicw Avenue

F.0. Bn: 101?

Palo Nito, CA 94304

\section{R. Crow}

Electric Fower Rescarch Institute

3412 llillview Avenue.

P.0. Box 10172

Palo Alto, CA 94304

M. Greenburger

Electric Pover Research Institute

3412 Hillview Avenue

P.0. Box 10412 .

Palo Alto, CA 94304 lio. of

Copios:

I. Henuinn

ricctric frum Research Inst itute

3412 Hill:iew Avenui?

P.O. Box 10472

Palo ntto, CA ga.30:

H. A. Konbers

Electric Fondr Research Institute

3412 Hillvich Avenue

P.0. Dox 10\$12

Palo Alto, CA .94304

fi. Searle

Electris. Power Research Institute

3412 Hillvien fivenue

P.0. Box 1041?

Palo Alto, CA 94301

S. Boris

Teknekron Corp.

2118 Hiluia Strect

Berkeley, CA 94704

J. W. Lafond

City of Seattic

Department of Lighting

1015 Third Avernes

Seattle, in 98104

R. Sheehan

City of Seatile

Department of Lighting

1015 Third Avenue

Seattle, HA 98104

J. MeFadden

Energy Inc.

Box 736

Idaho Falls, ID 83401

K. Blackburn

old West Regional Commission

Fratt Bullding, Suite 3 Uba

Billings, MT 59101

G. Culp

Culp. Diver, Guterson, and Grader

llouge Buildilly

Second and Cherry

Seattle, WA 98104

13. Goldhammer

Lloyd Building

700 H.F. Mult.momah

Portland, OR 97232

11. C. Elmore

Pacific Horthwest Utilities

Conference Committee

P.0. Box 1231

Wenatchee, WA 98801
110. of

Copies.

D. J. Levis

Public Service Euilding

920 S.ll. Sixth

Portland, OR 97204

R. A. lloraclecr

Hontana Power Comiany

40 last Brodalizy

Butte, lit $59 \% 0$

R. H. Bendio

Idaho Pover Company

P.0. Bos: 70

Boise, ID 83721

H. W. Ilerding

Washington liater Power

Company

P.0. Box 3727

Spukane, lifa yy220

H. G. Curtis

Public Pol:er Council

P. O. Bo: 1307

Vancouver, UA 98660

Scott Alstrom

Hestern States Hater Council

220 South Second East,

Suite 200

Salt Lake City, UT 84111

J. T. Stilcs

Pacific Po:yer and Light

Portland, OR 97204

L. Harris

Western Aluminum Producers

Association

P.0. Box 8484

Portland, OR 97207

K. Huller

Northern Plains Resource Councit

418 Stapleton Building

Billings, MT 5910l

J. Binanado

Pegional Planner

Gureau of Land llanagement

1.U. Bux 30157

Billings, HT 59107

H. Tomitinson

Environmental Library

Rin 203A Natural Sciences

University of luolılalla

Missoula, MT 59801

R. Doell

U.S. Geological Survey

354 Middlefield Road

Menlo Park, CA 94025 
ito. of

Cojics

B. Pourson

lis Litarary

Depmitianill of reolouy

01 yinpia, $\operatorname{lina} 9: 3501.1$

H. Neville

Idaho lagislative council

Stale lenese

Boise, $10 \quad 23702$

P. H. Rose, Pros.

Matheriatical Sciences

Northiest, Inc.

P.0. BOX, lES7

Bellevue, HA 93009

W. C. Hollemihaucr

Washingion Public forrer

Supply Sy'stem

3000 George lissliniogion liay

Richlond, UA 99355

F. Claggett

office of Comiunity Development

State of llasinington

400 Capitol Center Building

Olympia, Hn 98504

Battelle-Northuest

Human Affairs Research Center (IAAPC)

M. Green

J. A. Hetert

S. 11. Nealej:

H. Hertaugh

o. J. liervin

H. E. 01 s.en

R. E. Schuller

\section{ONSITE}

4 ERDA Richland Oferations office

P. W. Gottschalk

G. L. Liffick

R. H. Lindsey

B. J. Melton
Iin. of

Copins

91 rottelle-linrlinest:

Vi. J. Bair

C. H. Bloouster

d. B. Buralum (10)

H. E. Carter

D. B. Coarlock

i. Clement

J. H. Currie

A. E. Lavi.s

D. E. Deonigi

D. H. Draglich

D. L. Elliott:

L. E. Ericlison

D. W. Fraley

T. J. Foley

J. C. Fox

T. P. llarrington

P. L. Hendrickson

D. Hessel

R. L. Hoonel

J. J. Jacobsen

J. King

J. W. Litchfield

S. Marks

D. S. Renne

W. H. Richard

L. C. Schmid

P. J. Snorel:

!:. J. Swift

H. L. Templeton

B. E. Vaughan

R. D. Hidrig

G. L. Hilfert

Economics Library (20)

Technical Information files (5)

Technical Publications 